"A FEA e a USP respeitam os direitos autorais deste trabalho. Nós acreditamos que a melhor proteção contra o uso ilegítimo deste texto é a publicação online. Além de preservar o conteúdo, motiva-nos oferecer à sociedade o conhecimento produzido no âmbito da universidade pública e dar publicidade ao esforço do pesquisador. Entretanto, caso não seja do interesse do autor manter o documento online, pedimos compreensão em relação à iniciativa $\mathrm{e}$ o contato pelo e-mail bibfea@usp.br para que possamos tomar as providências cabíveis (remoção da tese ou dissertação da BDTD)." 


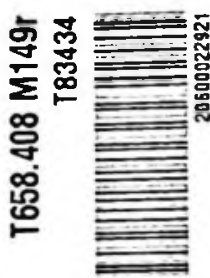

年 喜 
UNIVERSIDADE DE SÃO PAULO

FACULDADE DE ECONOMIA, ADMINISTRAÇÃO E CONTABILIDADE DEPARTAMENTO DE ADMINISTRAÇÃO

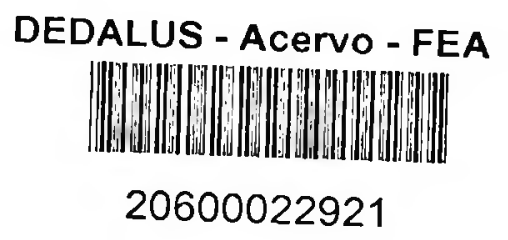

\title{
Responsabilidade Social Corporativa e a Criação de Veror pasa as Organizações: Um Estudo Multicasos
}

\author{
Cláudio Antonio Pinheiro Machado Filho
}

USP - FEA - SBD
DATA DA DEFESA ZOLOS OOZ

\begin{abstract}
Tese de doutorado apresentada à Faculdade de Economia, Administração e Contabilidade da Universidade de São Paulo, como requerimento para a obtenção do título de doutor em Administração.
\end{abstract}

Orientador - Prof. Dr. Decio Zylbersztajn

São Paulo

2002 
Reitor da Universidade de São Paulo

Prof. Dr. Adolpho José Melfi

Diretor da Faculdade de Economia, Administração e Contabilidade Prof. Dr. Eliseu Martins

Chefe do Departamento de Administração

Prof. Dr. Eduardo Vasconcellos 
Este trabalho é dedicado à minha mãe, Darclée, e à memória de meu pai, Cláudio. 
A number of disparate but interconnected forces such as deregulation and globalization, rapid advances in communications technology and the rise in the power of the consumer and civil society have now combined to bring corporate responsibility to prominence in many corporate boardrooms. In this information age, the ramifications of not addressing best practice in environment, workplace, marketplace, and community could range from bad press coverage to complete market exclusion. These are perilous times for the social construct of modern capitalism.

Andriof J. \& Mclntosh M., 2001 


\section{APRESENTAÇĀO}

Inicialmente, o foco da minha pesquisa estava circunscrito à questão da reputação corporativa, procurando analisar as estratégias empresariais para alcançar uma boa reputaçāo ou minimzar os riscos de perdas reputacionais. Nas fases que se sucederam durante a realização do trabalho, fui percebendo que esta temática estava intimamente ligada às questões da ética e da responsabilidade social corporativa.

O foco inicial ganhou abrangência, mas ao mesmo tempo levou a um grande risco de dispersão. E a cada dia, novos fatos e a crescente profusão de estudos e debates sobre a responsabilidade social corporativa criavam dificuldades para a finalização do trabalho, pelo dinamismo com que esta temática tem permeado os ambientes acadêmicos e empresariais no mundo todo.

Em dado momento da pesquisa, resignei-me a reduzir o seu escopo, procurando tratar especificamente das motivações que levam empresários e executivos a desenvolver atividades socialmente responsáveis $e^{\cdot}$ às formas organizacionais para uma melhor eficiência neste tipo de ação, utilizando o referencial teórico da Nova Economia Institucional. Mas ao consolidar este trabalho, percebo o quanto ainda falta a ser aprofundado nesta vertente de estudo. Ao mesmo tempo em que tal fato leva à angústia de não poder prover respostas conclusivas, surge o alento de que o trabalho possa ter contribuido levantando novas questōes a serem abordadas.

E como diz o meu orientador, talvez num gesto de amizade, uma tese de doutorado não é o final, mas apenas um marco intermediário na trajetória de um pesquisador. Seja como for, tal gesto me anima a dar continuidade às pesquisas nesta área, passando a considerar esta tese de doutorado apenas um etapa encerrada. Apenas uma etapa, espero, dentre as outras que virão. 


\section{AGRADECIMENTOS}

Agradeço inicialmente ao Prof. Decio Zylbersztajn, coordenador do PENSAVUSP, orientador e amigo, pela paciência e dedicação na orientação deste estudo. Ao longo dos anos de convivência, tem sido crescente a minha admiração pelo seu trabalho e caráter. Não tenho dúvidas de que a sua brilhante trajetória acadêmica é também consequência, além de suas inúmeras qualidades, da postura ética e socialmente responsável que sempre o direcionou.

A mesma constatação vale para o amigo Roberto Silva Waack, diretor do Grupo Orsa, por toda a sua trajetória executiva. A evidência de que sucesso e ética não são excludentes ganha reforço com o seu exemplo.

Aos sócios e executivos das empresas do Grupo Orsa (Orsa, Jari e Fundação), Perdigão, Sadia e Nestle, por dedicarem parte de seu escasso tempo para depoimentos que fundamentaram este trabalho. Em especial ao controlador do Grupo Orsa, Sérgio Garcia Amoroso, pelo seu exemplo de vida.

À Professora Rosa Maria Fischer, lembrando-me das suas aulas no curso de Metodologia, e seus constantes alertas para a necessidade de o pesquisador científico manter-se neutro em relação ao tema pesquisado, contrabalançando entusiasmo $e$ ceticismo. Tal ensinamento foi fundamental, especialmente em se tratando de um tema entusiasmante, como o da responsabilidade social.

Ao Professor Hélio Zylbersztajn, pelas importantes observações feitas durante o exame de qualificação, que foram muito relevantes para o delineamento e direcionamento da fase empírica do trabalho.

À Professora Elizabeth Farina, especialmente pela sua constante preocupação com a minha atividade acadêmica, na nossa convinência no âmbito das atividades do PENSA.

Ao Prof. Samuel Giordano, coordenador a cursos de extensão do PENSA, pelas importantes contribuições durante o nosso conv 'o constante. 
Ao Prof. Marcos Fava Neves, grande incentivador deste trabalho, dedico um agradecimento especial. Amplio o agradecimento para toda a sua equipe de novos e "veteranos" pesquisadores e amigos da FEA/RP, Luciano Thomé e Castro, Ana Maria, Aline Figueiroa, Carla, Rodrigo e Thais.

Aos profissionais de grande futuro (e presente), Matheus Kfouri Marino, André Meloni Nassar e Roberto Fava Scare, com os quais tenho aprendido muito nos últimos anos. O agradecimento se estende a todos os professores e pesquisadores do PENSA, Prof. Sigismundo Bialoskorski, Profa. Sylvia Saes, Prof. Marcos Sawaya Jank, Prof. Eduardo Spers, Prof. Sérgio Lazzarini, Prof. Paulo Furquim, Ferenc Bankuti, Carolina Graça, Christiane Lelles, Maristela Paes Leme e Fábio Mizumoto. Agradeço também ao apoio do acadêmico e futuro pesquisador Marco Antonio Conejero, e a toda a nova geração de estagiários do PENSA.

À equipe do Centro de Estudos em Administração do Terceiro Setor da USP (CEATS), em nome da pesquisadora Luciana Mendonça.

Aos amigos Márcio e Mariana Andrade, Carlos Eduardo e Elizabeth Ferraz, Graziela Zucolotto, Fernanda Brollo e ao meu sobrinho-irmāo Rodrigo Pinheiro Machado, pelo constante incentivo.

À Nice Santana, secretária do PENSA, pela paciência e apoio nas minhas atividades.

Por fim, agradeço a todos os meus familiares 


\section{RESUMO}

A atividade de negócios possui uma dimensão ética, complementar às suas dimensões econômica e legal. Acadêmicos de distintas correntes de pensamento compartilham esta percepção. Entretanto, o consenso desfaz-se quando se aprofunda o enfoque sobre a natureza dessa dimensão ética. Alguns compartilham a "visão dos stockholders" 1: os gestores têm a atribuição formal de incrementar o retorno dos acionistas ou cotistas da empresa. Para atingir tais objetivos, os gestores deveriam atuar somente de acordo com as forças impessoais do mercado, que demandam eficiência e lucro.

Outra corrente de pensamento argumenta com base na "visão dos

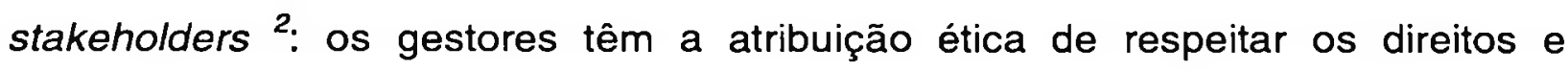
promover o bem entre todos os agentes afetados pela firma, incluindo neste conjunto de agentes os clientes, fornecedores, funcionários, os próprios acionistas ou cotistas (majoritários e minoritários), a comunidade local, bem com o os próprios gestores, que devem ser agentes a serviço deste grupo ampliad o. Evan \& Freeman (1988) argumentam que a visão neoclássica de que a responsabilidade social das organizações é a maximização da riqueza dos stockholders deve abranger uma abordagem teórica mais ampla, incorporando os demais stakeholders. É neste contexto que são debatidas atualmente as atividades de responsabilidade social corporativa.

O enfoque do presente trabalho dá destaque ao papel do ambiente institucional em induzir as ações de responsabilidade social das empresas. As instituições importam como fator motivacional indutor do tipo de conduta dos agentes, em aspectos econômicos, legais e éticos. Assim, alterações no ambiente

\footnotetext{
${ }^{1}$ Os stockholders são formados por sócios e acionistas.

2 Os stakeholders sāo constituídos, além dos próprios sto holders, pelos funcionários, fomecedores, clientes, consumidores, investidores, comunidades, governos, ntre outros agentes que afetam ou sāo afetados direta ou indiretamente pela empresa (WRIGHT P. ; Ki LL L M. ; PARNELL, J., 2000). Em síntese, os stakeholders sāo aqueles grupos ou indivíduos com $c$ quais a organização interage ou tem interdependências, ou qualquer individuo ou grupo que pode a ar ou ser afetado pelas ações, decisões, políticas, práticas ou objetivos da organização.
} 
institucional, como consequência do processo de integração dos mercados, têm sido um dos importantes vetores de mudanças comportamentais das empresas. $\mathrm{O}$ trabalho explora a interface entre ambiente institucional, reputação, ética nos negócios e, como decorrência, as ações de responsabilidade social das empresas.

A partir de estudos de caso de empresas atuando nos negócios agroindustriais no Brasil (Sadia, Nestlé, Perdigão, Jari Celulose e Orsa), o estudo distingue as motivações que têm levado estas empresas a se engajarem em práticas de responsablidade social, discutindo os tipos alternativos de estrutura organizacional adotados para o desenvolvimento destas ações.

Como conclusão, este estudo expõe que, embora com motivações distintas, as empresas analisadas percebem retornos positivos à imagem corporativa decorrentes das ações de responsabilidade social, o que as leva a incorporar esta temática em seus modelos de gestão estratégica.

O estudo resgata a afirmativa de North (1990) de que as "instituições importam" e são passíveis de análise e aperfeiçoamento para a melhoria da performance econômica e social dos agentes. Neste sentido, as mudanças institucionais, decorrentes da evolução tecnológica, que estão levando à intensificação do fluxo informacional e à internacionalização dos mercados, bem como novos marcos regulatórios nas questōes ambientais e sociais têm induzido as empresas a desenvolverem ações visando a manter ou ganhar reputação. $E$ nesse processo de busca da reputação, cresce a preocupação com o comportamento ético e socialmente responsável. 


\section{ABSTRACT}

The issue of Corporate Social Responsibility is subject of growing debate in the academic environment. It is widely accepted that business has an ethical dimension, besides the economic and legal dimensions. But there is no consensus about the nature of the ethical dimension and to whom they are owed.

A group of scholars support the "stockholder view": the idea is that the only social responsibility of business managers is to increase profits of the company's owners, respecting the rules, without fraud or deception. Other group support the "stakeholder view": business managers have duties to several groups, all of those affected by the firm's decisions, including clients, suppliers, employees, community and so on.

The present thesis will evaluate these competing views under the framework of institutions where the business activity is played. The point is that the institutional set is the main motivational factor inducting the firm's behavior regarding ethical and social responsibility issues. The changes in the global institutional environment, both formal and informal, as a consequence of the growing market integration are the driving forces in the behavior changes of firms worldwide and specifically within the brazilian context.

This study focus on the links between institutional environment, business ethics, reputation and corporate social responsibility of five brazilian companies from the food, pulp and paper agribusiness fields (Nestlé, Sadia, Perdigão, Jari Celulose and Orsa group). All of them have recently launched social responsibility programs. The study discuss the main incentives for the companies to engage in such programs.

Although with different motivations, the owners and executives of companies have the perception of positive returs of social responsibility actions 
to the corporate image. They report a growing concern with such issue, which is becoming part of their corporate strategic planning models.

As a conclusion, the main evidence of the cases supports the statement that "institutions matter" to the economic and social performance of business agents. The new institutional framework, derived from technological changes specifically in communications, new social and environmental regulations and consumer behavior changes are raising the ethical concerns of companies, inducing them to develop social responsibility actions as a strategy to gain or at least mantain their reputational capital. 


\section{ÍNDICE}

CAPÍTULO 1 - O PROBLEMA DE PESQUISA......................................................................................16

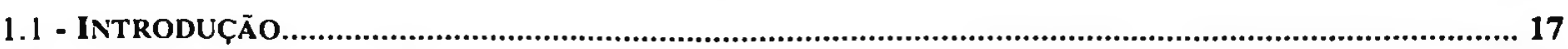

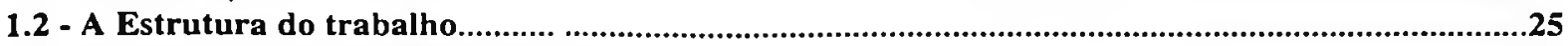

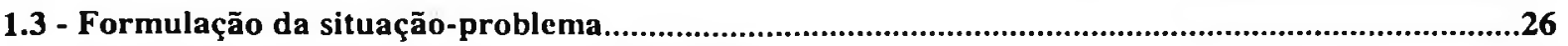

1.4 - Justificativa e importância do tema escolhido....................................................................................27

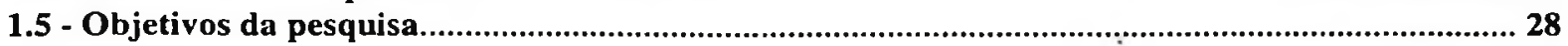

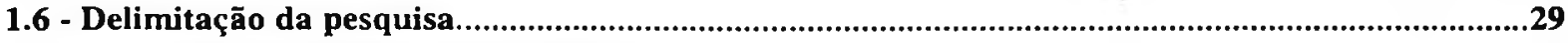

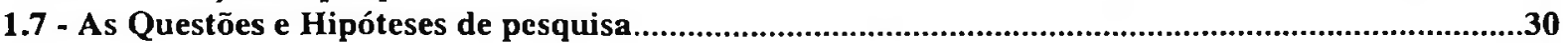

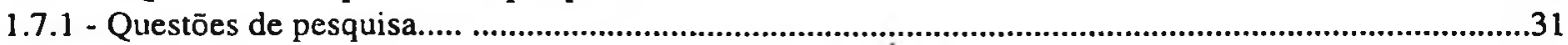

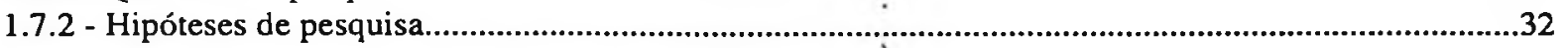

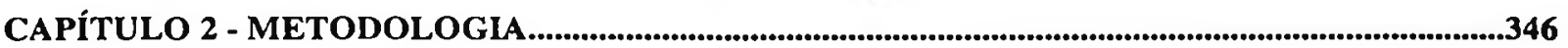

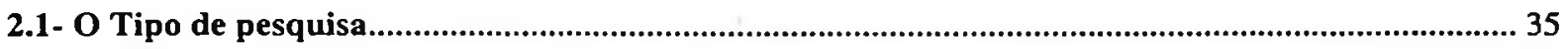

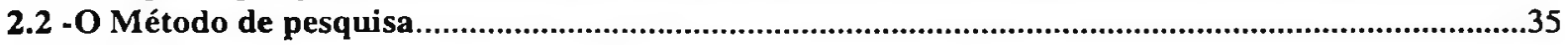

2.2.1 - O Método do estudo de casos múltiplos..............................................................................................

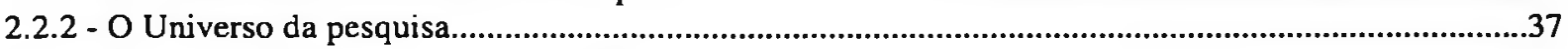

2.2.3 - Coleta, análise e tratamento dos dados.................................................................................................38

CAPÍTULO 3 - REVISÃO DA LITERATURA...............................................................................

3.1 - O Debate da empresa socialmente responsável.........................................................................42

3.1 .1 - Ética e responsabilidade social...............................................................................................................50

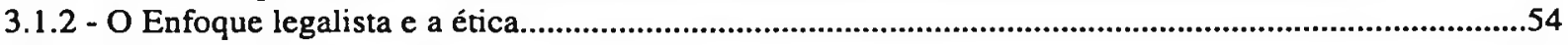

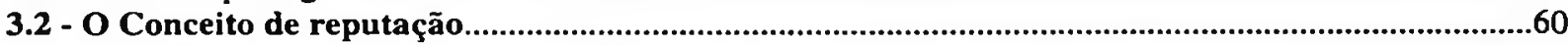

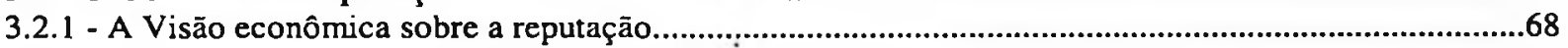

3.2.1.1 - Os Pressupostos comportamentais da Economia dos Custos de Transação.......................................69

3.2.1.2 - Comportamento oportunista e reputação................................................................................................77

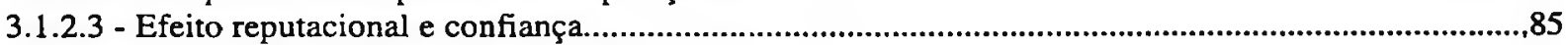

3.2.1.4 - A Filantropia corporativa e os ganhos de reputaçāo.................................................................................87

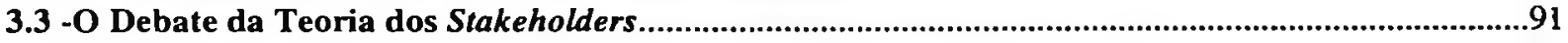

3.3.1 - A Teoria dos Stakeholders e as açōes de responsabilidade social........................................................91

3.3.2 - A Visão crítica à teoria dos Stakeholders.................................................................................................96

3.4 - A Estrutura organizacional para lidar com atividades de responsabilidade social.........................98

3.4.1 - Governança corporativa e a teoria dos stakeholders...................................................................................98

3.4.2 - O terceiro setor e sua relaçāo com o ambiente empresarial.....................................................................106

3.5 - A Importância das ações sociais - evidências empíricas no contexto empresarial.............................109

3.5.1 - Melhoria da performance financeira e acesso ao capital dos investidores.............................................111

3.5.2 - Melhoria da imagem e da reputação..............................................................................................................116

3.5.3 - Demanda e relaçōes com o consumidor............................................................................................118

3.5.4 - Percepções do empresariado brasileiro sobre o voluntariado corporativo...........................................120

3.5.5 - Aspectos Institucionais - balanço e certificação social............................................................................122

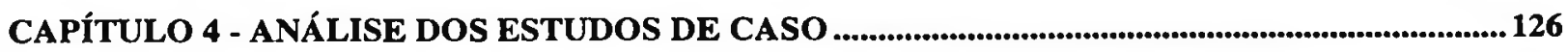

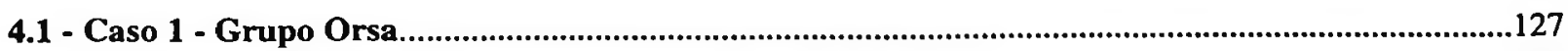

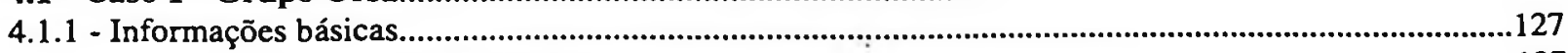

4.1.1.1 - Orsa Celulose, Papel e Embalagens.......................................................................................................127

4.1.1.2 - Jari Celulose.....................................................................................................................................129

4.1.2 - As atividades de responsabilidade social do grupo Orsa.....................................................................131

4.1.3 - A Estrutura organizacional para lidar com as atividades de responsabilidade social- exemplo Jari...135

4.1.4 - A Integraçāo das açōes da Fundação e as empresas (Orsa ، juri)............................................................137

4.1.5 - Evidências de retorno à imagem corporativa..............................................................................................138

4.2 - Caso 2 - Nestlé......................................................................................................................................140

4.2.1 - Informações básicas......................................................................................................................140

4.2.2 - As Atividades de responsabilidade social da Nestlé............. . .............................................................141 
4.2.3 - A estrutura organizacional para lidar com as atividades de responsabilidade social...........................144

4.2 .4 - Evidências de retorno à imagem corporativa..............................................................................145

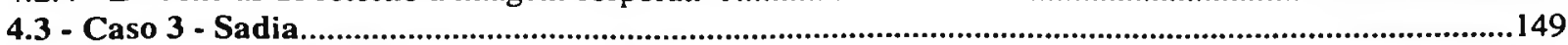

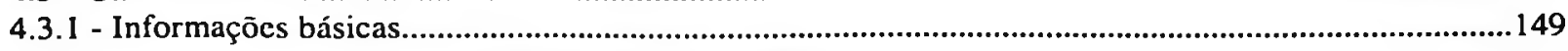

4.3.2 - As Atividades de responsabilidade social da Sadia ...................................................................150

4.3.3 - A Estrutura organizacional para lidar com as atividades de responsabilidade social..........................152

4.3.4 - Evidências de retorno à imagem corporativa............................................................................153

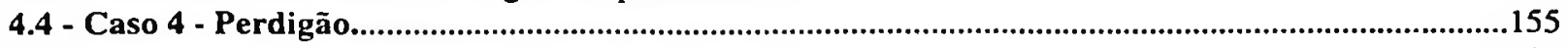

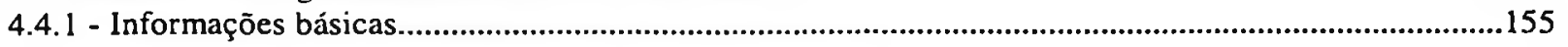

4.4.2 - As Atividades de responsabilidade social da Perdigão.............................................................157

4.4.3 - A Estrutura organizacional para lidar com as atividades de responsabilidade social...........................161

4.4 .4 - Evidências de retorno à imagem corporativa...........................................................................161

4.5 - A nálise comparativa dos casos à luz do referencial teórico........................................................163

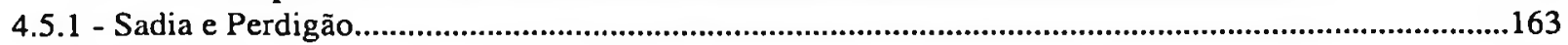

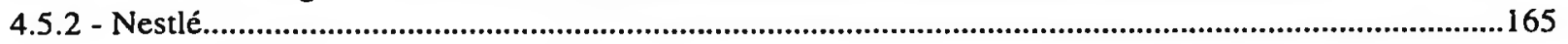

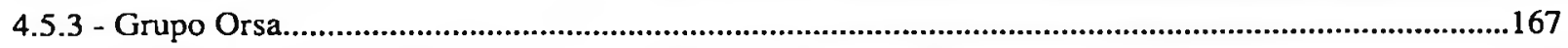

4.6 - Relação entre os estudos de caso e as hipóteses de pesquisa propostas...........................................168

4.7 - Classificação das empresas com base nos modelos apresentados....................................................171

4.7.1 - O Modelo de Fombrun (2000)....................................................................................................171

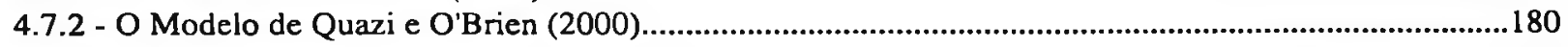

4.7 .3 - O Modelo proposto no presente trabalho......................................................................................181

\section{CAPÍTULO 5}

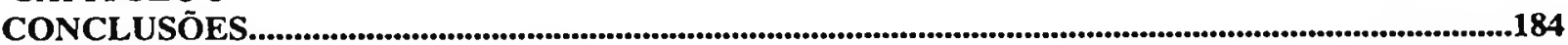

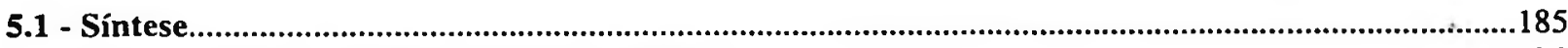

5.2 - Limitações do trabalho - futuras pesquisas..........................................................................186

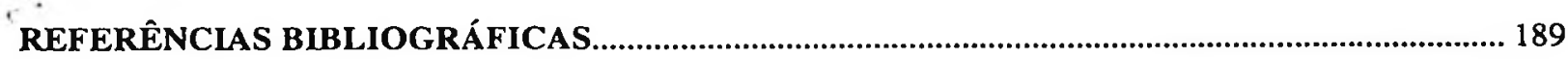




\section{Lista de Figuras}

Figura 1- Construçāo de modelo: $\mathrm{O}$ ambiente institucional e as atividades de negócios..................24

Figura 2 - Modelo bi-dimensional de responsabilidade social corporativa.......................................48

Figura 3 - Interrelação entre identidade e reputação corporativa.............................................67

Figura 4 - Interrelação entre os constituintes chave da reputação.................................................68

Figura 5 - O Modelo de criação de valor a partir de ações de responsabilidade social......................89

Figura 6 - O Modelo da Teoria dos Stakeholders.....................................................................92

Figura 7 - Três estruturas alternativas para desenvolver açōes de responsabilidade social.............. 101

Figura 8 - As dimensōes do Fundo Ethical.....................................................................115

Figura 9 - Relação entre a Orsa, a Jari e a Fundação Orsa..............................................................133

Figura 10 - O Modelo de Quazi e O'Brien e a classificação das empresas analisadas......................180

Figura 11 - Classificação das empresas com base na forma de implementação das ações sociais....182

\section{Lista de Tabelas}

Tabela 1 - Classificação das empresas selecionadas para a pesquisa qualitativa 38

Tabela 2 - Percep̧̧ão de empresários sobre os benefícios de uma reputação corporativa superior.

Tabela 3 - Efeitos das açōes de responsabilidade social de acordo com o stakeholder envolvido .95

Tabela 4 - Relevância dos itens de responsabilidade social na análise da companhia......................113

Tabela 5 - Aspectos mais importantes para o julgamento de uma empresa.

Tabela 6 - Comportamento dos consumidores nos vários países quanto à premiação ou puniçāo da empresa socialmente responsável ou irresponsável.

Tabela 7 - Percepçōes do empresariado brasileiro sobre as açōes de voluntariado corporativo

Tabela 8 - Balanço social - panorama internacional. 122

Tabela 9 - Expedição de caixas e chapas de papelão ondulado no Brasil........................................127

Tabela 10 - Principais empresas produtoras de celulose de mercado no Brasil...............................130

Tabela 11 - Investimentos e número de assistências da Fundação: Orsa.........................................134

Tabela 12 - Pontuação obtida pela Orsa para inclusão entre as 1C!) melhores empresas para trabalhar da revista Exame.

Tabela 13 - Classificação das empresas do setor de alimentos no rasil, 2000 .141 
Tabela 14 - Pontuaçāo obtida pela Nestlé para a sua inclusão entre as 100 melhores empresas para se trabalhar da revista Exame.

Tabela 15 - Atribuiçāo de pontos à Nestlé no Guia Exame de Boa

Cidadania Corporativa, 2001

Tabela 16 - As empresas mais admiradas do mundo - setor de alimentos, 2002 ............................147

Tabela 17 - Receita da Sadia em 1999 e 2000 ..............................................................................150

Tabela 18 - Evoluçāo do faturamento bruto da Perdigão no período 1994-2000...............................155

Tabela 19 - Composição acionária da Perdigão..........................................................................156

Tabela 20 - Evolução do resultado líquido, investimentos e remuneraçāo do acionista da Perdigão no periodo 1994-2000......................................................................157

Tabela 21 - Atribuição de pontos à Perdigão no Guia Exame de Boa

Cidadania corporativa, 2000.

Tabela 22 - Relação entre as empresas analisadas e os impactos decorrentes das ações de responsabilidade social (comunidade).

Tabela 23 - Relação entre as empresas analisadas e os impactos decorrentes das açōes de responsabilidade social (mídia).

Tabela 24 - Relação entre as empresas analisadas e os impactos decorrentes das ações de responsabilidade social (ativistas).

Tabela 25 - Relação entre as empresas analisadas e os impactos decorrentes das ações de responsabilidade social (investidores).

Tabela 26 - Relação entre as empresas analisadas e os impactos decorrentes das ações de responsabilidade social (funcionários).

Tabela 27 - Relação entre as empresas analisadas e os impactos decorrentes das ações de responsabilidade social (consumidores).

Tabela 28 - Relação entre as empresas analisadas e os impactos decorrentes das ações de responsabilidade social (agentes reguladores).

Tabela 29 - Relação entre as empresas analisadas e os impactos decorrentes das ações de responsabilidade social (parceiros comerciais)

\section{ANEXOS}

Anexo 1 - Instrumento de pesquisa qualitativo. .203

Anexo 2 - Entrevistas realizadas. 


\section{CAPÍTULO 1 - O PROBLEMA DE PESQUISA}

Why do managers regularly allocate corporate resources to doing good?

Fombrun, 2000 


\section{1 - INTRODUÇÃO}

A atividade de negócios possui uma dimensão ética, complementar às suas dimensões econômica e legal. Acadêmicos de distintas correntes de pensamento compartilham esta percepção. Entretanto, o consenso desfaz-se quando se aprofunda o enfoque sobre a natureza dessa dimensão ética. Alguns compartilham a "visão dos stockholders". os gestores têm a atribuição formal de incrementar o retorno dos acionistas ou cotistas da empresa. Para atingir tais objetivos, os gestores deveriam atuar somente de acordo com as forças impessoais do mercado, que demandam eficiência e lucro.

Outra corrente de pensamento argumenta com base na "visão dos stakeholders". os gestores têm a atribuição ética de respeitar os direitos e promover o bem entre todos os agentes afetados pela firma, incluindo neste conjunto de agentes os clientes, fornecedores, funcionários, os acionistas ou cotistas (majoritários e minoritários), a comunidade local, bem como os gestores, que devem ser agentes a serviço deste grupo ampliado. Evan e Freeman (apud BEAUCAMP e BOWIE, 1988) ${ }^{3}$ argumentam que a visão neoclássica de que a responsabilidade social das organizações é a maximização da riqueza dos stockholders deve abranger uma abordagem teórica mais ampla, incorporando os demais stakeholders.

Ambas as visões convergem no sentido de que as empresas têm uma função social a cumprir na sociedade e, desta forma, possuem atribuições éticas, mas a discordância fundamental é sobre a natureza das atribuições éticas e quem se beneficiará com elas (DIENHART, 2000). É neste contexto que são debatidas atualmente as atividades de responsabilidade social corporativa.

\footnotetext{
${ }^{3}$ EVAN, W.M. ; FREEMAN, R. E. A Stakeholder Theory of the Fir of the Modern Corporation: Kantian Capitalism. In: BEAUCAMP, T.L.; BOWIE, N.E. Ethical Theory an. Jusiness. N.J.: Prentice Hall, 1988.
} 
De acordo com o Business Social Responsible Institute ${ }^{4}$ (BSR, 2001), não existe uma definição unanimemente aceita para o termo responsabilidade social corporativa, mas, de forma ampla, a expressão se refere a decisões de negócios tomadas com base em valores éticos que incorporam as dimensões legais, o respeito pelas pessoas, comunidades e meio ambiente.

O BSR Institute sustenta que o conceito de empresa socialmente responsável se aplicará àquela que atue no ambiente de negócios de forma que atinja ou exceda as expectativas éticas, legais e comerciais do ambiente social na qual a empresa se insere. No mesmo sentido, o Instituto Ethos (2001) caracteriza da seguinte forma a ação socialmente responsável das empresas:

A responsabilidade social das empresas tem como principal característica a coerência ética nas práticas e relações com seus diversos públicos, contribuindo para o desenvolvimento contínuo das pessoas, das comunidades e dos relacionamentos entre si e com o meio ambiente. Ao adicionar às suas competências básicas a conduta ética e socialmente responsável, as empresas conquistam o respeito das pessoas e das comunidades atingidas por suas atividades, o engajamento de seus colaboradores e a preferência dos consumidores

Friedman (1970) é um dos principais defensores da visão dos stockholders, em contraposição à visão dos stakeholders. $\mathrm{O}$ argumento é $O$ de que se os administradores incrementam os lucros e se utilizam destes lucros para aumento do valor da empresa, eles estão respeitando os direitos de propriedade dos acionistas/cotistas das empresas e, desta forma, promovendo de forma agregada o bem-estar social. Se os administradores se atêm a problemas de cunho social em decisões do dia-a-dia, por exemplo, podem violar suas atribuições de defesa dos interesses da empresa e interferir na habilicade do mercado em promover o

\footnotetext{
${ }^{4}$ Principal entidade mundial na área de responsabilidade sc al, reunindo 1600 empresas que representaram um faturamento total em torno de US\$ 1,5 tri äo de dólares em 1999.
} 
bem-estar geral. O autor argumenta que os gestores podem usar as ações de responsabilidade social como meio para desenvolver suas próprias agendas sociais, políticas e profissionais, às expensas dos acionistas. De acordo com esta visão, os recursos destinados a ações de responsabilidade social seriam mais sabiamente gastos, sob uma perspectiva social, no incremento da eficiência da firma.

A visão crítica da relevância das atividades de responsabilidade social corporativa considera que estes esforços são incompativeis com o objetivo de maximização de lucro da empresa. Friedman (op.cit.) destaca que o engajamento em atividades de responsabilidade social pode dar origem a um problema de agência, ou seja, um conflito de interesses entre o principal (acionista) e o agente (gestor).

A relação agente-principal é sempre conflituosa quando um determinado indivíduo (agente) age em nome de outro, o chamado "principal", e os objetivos de ambos não coincidem integralmente. Assim, numa relação empregador/empregado, o "principal" busca implementar uma estrutura de incentivos e monitoramento visando a alinhar os interesses do agente aos seus interesses. A eficiência nas relações de agência (maior alinhamento) se dá quando algumas premissas estão presentes (BESANKO, et. al., 2000):

1. Agentes não possuem informações ocultas (ausência de assimetria informacional). O principal sabe o que constitui uma ação eficiente e qual o produto esperado.

2. O principal tem completa informação sobre as ações e resultados.

3. Os agentes atuam sob baixo risco (são conscientes do que receberão com a conduta alinhada ao interesse do principal). 
As premissas 1 e 2, que embasam uma relação eficiente de agência, estão claramente em choque com os objetivos difusos da teoria dos stakeholders, conforme destaca Jensen (2000).

Segundo Sternberg (1999):

Longe de se tornar uma fonte de melhorias, a doutrina dos stakeholders é fundamentalmente distorcida, incapaz de prover melhor governança corporativa, performance e conduta dos negócios. $\dot{E}$ intrínsecamente incompativel com a atividade de negócios e sistematicamente mina os direitos de propriedade e a transparência das atividades. Pode se usada para racionalizar praticamente qualquer tipo de intervenção governamental, não importando quão intrusiva ou restritiva.

Friedman (apud BORGER, 2001) sintetiza a visão liberal sobre a questão ética da seguinte forma: o objetivo mais importante dos liberais é deixar os problemas éticos a cargo do próprio indivíduo. Os problemas éticos realmente importantes são os que um indivíduo enfrenta numa sociedade livre - o que ele deve fazer com sua liberdade.

Rebatendo esta afirmativa sobre a questão da ética e da responsabilidade social, os liberais sustentam que a função-objetivo das empresas deve ser sempre a busca do maior retorno possivel para os seus acionistas/cotistas, dentro de um conjunto de regras do jogo, no qual o comportamento ético empresarial se limite ao cumprimento destas regras. Passa a ser uma decisão dos indivíduos (sócios/cotistas), que recebem os retornos gerados pela empresa o que fazer com tais recursos. $O$ indivíduo pode acumular riqueza, ou alternativamente, distribuir benefícios para a sociedade. Neste contexto, a decisão ética passa a ser problema intrínseco do indivíduo, não da empresa. $^{5}$

\footnotetext{
${ }^{5}$ Conforme questionamento provocativo de Friedman (New York Times Maganize, 13 set. 1970): "What does it mean to say that business has responsibilities? Only people can have responsibilities. A corporation is an artificial person and in this sense may have antificial responsibilitis.s. but business as a whole cannot be said to have responsibilities, even in this vague sense. The first step tc.,ard clarity to examining the doctrine of the social responsibility of business is to ask precisely what it implies fi: whom".
} 
Críticas ao argumento sustentado por Friedman existem, tal como a ilustrada por Sen (1999, p.31):

Por que deveria ser unicamente racional empenhar-se pelo autointeresse excluindo todo o resto? Evidentemente, pode não ser de todo absurdo afirmar que a maximização do auto-interesse não é irracional, pelo menos nāo necessariamente, mas asseverar que tudo o que não for maximização do auto-interesse tem de ser irracional parece absolutamente insólito.

Sen (op.cit., p.35), vai mais além:

Vale a pena comentar - correndo o risco de apontar o óbvio - que negar que as pessoas sempre se comportam de modo exclusivamente auto-interessado não equivale a afirmar que elas sempre agem com altruísmo. Seria extraordinário o auto-interesse não ter um papel importantíssimo em numerosas decisões e, de fato, as transações econômicas normais entrariam em colapso se 0 auto-interesse não desempenhasse um papel substancial em nossas escolhas. A verdadeira questão é se existe ou não uma pluralidade de motivações ou se unicamente $o$ auto-interesse rege os seres humanos.

Ou seja, Sen critica o conceito da racionalidade maximizadora neoclássica, considerando a possibilidade de o altruismo trazer benefícios para o tomador de decisão.

Alinhados à visão sustentada por Sen, um conjunto de pesquisadores defende que as atividades de negócios estão inseridas em um contexto mais amplo, sendo parte de uma matriz social, com responsabilidades além da perspectiva tradicional de maximização de lucro (FREEMAN, 1984; AOKI, 1984; QUAZI, 1997; CARROLL, 1979, 1999; FOMBF:UN, 1996). Esse grupo também tem identificado nas atividades de responsasilidade social corporativa um 
potencial fator de aumento do valor da empresa, promoção de imagem e reputação, da redução de custos, da elevação da moral de funcionários e da construção de lealdade por parte dos clientes, entre outros benefícios. Conforme Solomon (apud ARRUDA, 2002, p.12)

...na ética, a armadilha mais traiçoeira é a polarização entre o que se deve fazer e o que não é do interesse pessoal de ninguém, como se essas coisas fossem necessariamente opostas. $O$ truísmo de que os negócios vão bem fazendo o bem revela uma forma mais correta de refletir sobre essas coisas.

Nesta perspectiva, a atividade dos negócios deveria incorporar beneficios sociais juntamente com os ganhos econômicos que a empresa busca. Estes trabalhos refletem as boas intenções dos autores, mas em certos casos ignoram a realidade institucional e principalmente das organizações.

Embora, em princípio, essas visões sobre o comportamento ético e socialmente responsável das empresas tenham naturezas distintas, o presente trabalho parte da premissa de que estas divergências são relativizadas em função do ambiente institucional em que a atividade de negócios ocorre. O propósito do presente estudo é o de tecer uma análise positiva com base teórica definida pela teoria dos incentivos no âmbito da Nova Economia Institucional. Neste contexto, é relevante a definição que North (1990) oferece para caracterizar a importância do ambiente institucional e sua relação com a performance e conduta dos agentes econômicos num determinado mercado, aplicando esta abordagem à análise da história econômica.

${ }^{6}$ SOLOMON, Robert C. A melhor maneira de fazer negócios: como a integridade pessoal leva ao sucesso corporativo. In: ARRUdA, Maria Cecilia Coutinho de. Código de Ética. São Paulo: Negócio Editora, 2002. 
O autor define as instituições como sendo os limites que as sociedades se impōem para estruturar as relaçōes políticas, econômicas e sociais. Assim, as instituições podem ser tanto formais (constituiçōes, leis, direitos de propriedade) como informais (crenças, tradições, códigos de condutas e costumes). North procura estabelecer uma relação entre instituições e organizações: as instituições constituem as "regras do jogo" e as organizações são os "jogadores.

De acordo com essa abordagem, as limitações que são impostas pelo contexto institucional ajudam a definir o conjunto de oportunidades e, como conseqüência, os tipos de organizações que serão criadas e sua forma de conduta. As organizaçōes existentes em um determinado mercado e a forma como interagem são influenciadas pelo ambiente institucional. Mudanças neste ambiente podem levar a mudanças na forma de conduta das organizações, e ao surgimento de outras.

North sugere que as instituições e a efetividade do enforcement (fazer valer) determinam os custos de transação entre agentes em um determinado mercado. Instituições efetivas são aquelas que elevam os benefícios de soluçōes cooperativas ou os custos de defecção, em termos de teoria dos jogos. Quanto aos cuistos de transação, reduzem os custos de funcionamento do sistema econômico (trocas), aumentando os ganhos do comércio. Neste sentido, instituições efetivas são aquelas que motivam uma conduta ético/legal das empresas.

Dienhart (2000) propõe um esquema para a estruturação de um modelo que permita um melhor entendimento da complexa inter-relação entre os aspectos psicológicos, éticos, econômicos e legais que compõem o ambiente institucional onde se desenvolvem as atividades de negócios (Figura 1). 
Figura 1 - Construção de modelo: $O$ ambiente institucional e a atividade de negócios

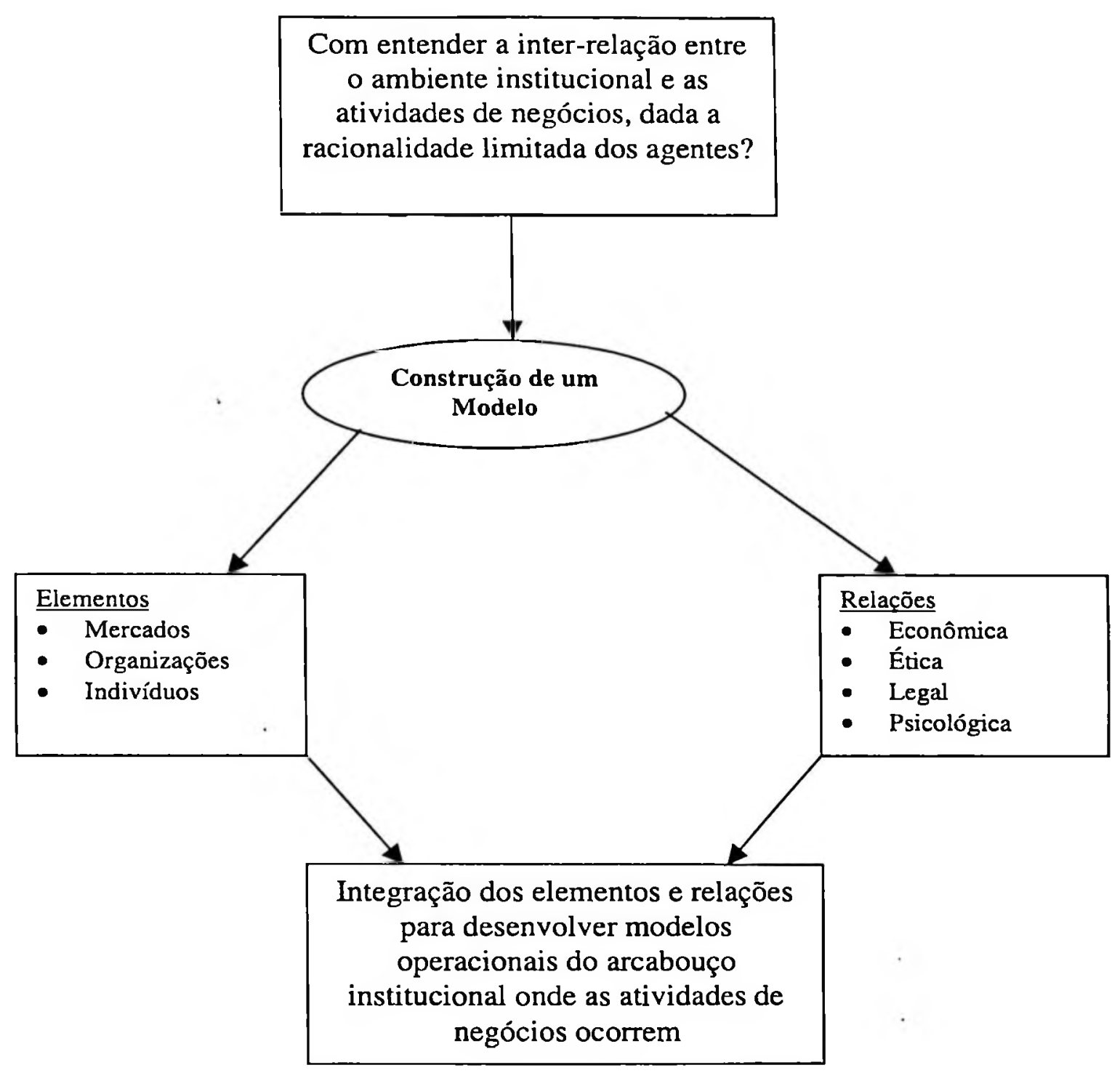

Fonte: Dienhart, 2000.

Dienhart propõe que para entender a interrelação entre o ambiente institucional e a atividade de negócios, considerando-se a racionalidade limitada dos agentes, é necessária a estruturação de um modelo que integre os elementos que 
interagem no ambiente institucional (mercado, organizações e indívíduos) e as relações existentes nas dimensões econômica, ética, legal e psicológica. 0 contexto institucional, em última análise, é que balizará em cada situação a natureza, o grau e o tipo de conduta socialmente responsável que a empresa deverá manifestar, mantendo a sua função básica de criação de valor/aumento da riqueza para os seus acionistas/cotistas.

As instituições são essencialmente mecanismos sociais que usam regras e princípios éticos, econômicos e legais para coordenar "comportamentos" (DIENHART, op.cit.). O ambiente institucional (formal e informal) define conjuntos de direitos de propriedade sobre ativos de valor, o que por sua vez definirá ações estratégicas das corporações. Um exemplo é a lei norte-americana de responsabilidade civil, que prevê multas para empresas que afetarem a sociedade, o que leva as empresas a ações focalizadas de estabelecimento de normas e códigos de ética internos. Ou seja, instituições afetam as organizaçōes.

Visto de outra forma, a natureza das ações éticas no âmbito das empresas, o ponto central da discórdia entre a visão dos stockholders e stakeholders, passa a ser relativizada. Dependendo do contexto institucional onde a atividade de negócios se desenvolve, o comportamento ético pode ser basicamente 0 cumprimento de responsabilidades legais. Em outros contextos, a ação social deve ter um escopo mais amplo, incorporando por exemplo ações filantrópicas em uma determinada comunidade, quando normas informais previrem sanções aos agentes.

\section{2 - A ESTRUTURA DO TRABALHO}

O presente trabalho está estruturado da seguinte forma:

O capítulo 1 apresenta o problema de pequisa, objetivos, delimitação do universo da pesquisa e as questões e hipóteses. 
O capítulo 2 apresenta a metodologia da pesquisa a ser empregada.

O capítulo 3 trata do debate sobre a responsabilidade social corporativa, e da inserção dos conceitos de ética, reputação e filantropia nas atividades dos negócios. $O$ debate apresenta basicamente as visões pró e contra as ações de responsabilidade social, do ponto de vista dos benefícios gerados para as empresas envolvidas nesta prática (visão dos stakeholders versus visão dos stockholders). É apresentada também uma revisão de estudos empíricos que procuram associar as práticas de responsabilidade social com a geração de valor para as empresas.

O capítulo 4 apresenta os resultados dos estudos de caso empíricos analisados, procurando estabelecer relações entre os estudos de caso e o aparato teórico utilizado.

Finalmente, o capítulo 5 destaca as conclusões do trabalho.

\section{3 - FORMULAÇÃO DA SITUAÇÃO - PROBLEMA}

O problema de investigação está centrado nas seguintes questões: $O$ que incentiva as empresas a se engajarem em práticas socialmente responsáveis? Como as empresas se estruturam em termos organizacionais para lidar com as atividades de responsabilidade social?

A premissa básica do problema de investigação é a de que o ambiente institucional que cerca a atividade de negócios define o tipo de comportamento das empresas em relação às ações de responsabilidade social a serem implementadas.

Essa premissa não é, em princípio, divergente da visão mais crítica da responsabilidade social corporativa, que aceita pragmaticamente estas ações 
desde que se vislumbrem retornos para as empresas. Mesmo Friedman, um crítico mordaz da visão benigna normativa do papel social das empresas, corrobora esta visão:

No clima presente de opinião, com a disseminada aversão ao capitalismo, lucros e corporaçōes sem alma, ações sociais são uma maneira para as corporaçōes gerarem goodwill, por meio de gastos extraprodução inteiramente justificados sob a ótica do auto-interesse (FRIEDMAN, 1970).

\section{4- JUSTIFICATIVA E IMPORTÂNCIA DO TEMA ESCOLHIDO}

De acordo com Castro (1978), para a escolha de um tema de pesquisa devem ser observados os critérios de originalidade, importância e viabilidade.

Quanto à originalidade, embora o tema esteja sendo cada vez mais debatido na mídia e nos ambientes de negócios e acadêmicos do Brasil, parte-se em geral de uma visão normativa do papel reservado para as organizações empresariais na sociedade. Neste trabalho, o enfoque parte de uma visão positiva do papel das empresas quanto às ações de responsabilidade social. O enfoque de originalidade é dado pela tentativa de se utilizar do aparato teórico da Nova Economia Institucional para explicar os incentivos das empresas para a conduta ética e socialmente responsável. Procurou-se também abordar a questão da eficiência organizacional para o desenvolvimento das atividades de responsabilidade social, com base nas teorias da Agência e da Economia dos Custos de Transação (ECT).

A importância do tema, como já salientado anteriormente, decorre do fato observado empiricamente do crescente envolvimento empresarial em atividades de responsabilidade social. Entretanto, 0 tema da 
responsabilidade social corporativa carece de um maior aparato teórico para dar suporte ao processo de tomada de decisão no ambiente empresarial. Buscando preencher parte desta lacuna, o presente estudo visa a apresentar alguns elementos conceituais, com base no arcabouço teórico proposto, e estabelecer relações com os estudos de caso analisados.

Quanto à viabilidade, é factivel a exploração do tema a partir do referencial teórico proposto. Conforme será explicado no capítulo de metodologia (capítulo 2), o método de estudo multicasos se aplica de forma adequada aos objetivos propostos no presente trabalho.

\section{5 - OBJETIVOS DA PESQUISA}

O presente estudo não busca o aprofundamento da visão filosófica e ideológica dos valores e princípios dos indivíduos ante suas decisões no ambiente de negócios, que levem a uma maior incidência dos tipos de ações de responsabilidade social a serem empregadas. O estudo procurará tão somente expor evidências acerca das motivações que levam à adoção das práticas de responsabilidade social corporativa.

Com relação ao objetivo geral, o trabalho deverá apresentar o debate sobre a empresa socialmente responsável, e as interfaces existentes entre os conceitos de ética nas organizações, a reputação corporativa e a responsabilidade social corporativa. $O$ trabalho explora as percepções de empresários e executivos ligados a empresas que desenvolvem ações de responsabilidade social.

Quanto aos objetivos específicos, o trabalho visa a: 
- Avaliar diferentes motivações de empresários e executivos de empresas que realizam ações de responsabilidade social corporativa, e as percepções sobre os possíveis ganhos de imagem corporativa.

- Avaliar os possíveis impactos das ações de responsabilidade social corporativa nos grupos interessados (stakeholders).

- Discutir a eficiência das diferentes formas de estrutura organizacional em lidar com ações de responsabilidade social.

\section{6 - DELIMITAÇÃo dA PESQUISA}

A pesquisa enfocou cinco empresas do setor de agronegócios atuantes no Brasil. A delimitação do conjunto de agentes ligados aos sistemas agroindustriais é apresentada por Goldberg (apud Zylbersztajn e Neves, 2000) ${ }^{7}$ :

... tal sistema inclui o mercado de insumos agrícolas, a produção agrícola, operações de estocagem, processamento, atacado e varejo, demarcando um fluxo que vai dos insumos até o consumidor final. $O$ conceito engloba todas as instituições que afetam a coordenação dos estágios sucessivos do fluxo de produtos, tais como as instituiçōes governamentais, mercados futuros e associações de comércio.

Partindo dessa delimitação, o estudo envolveu empresas dos setores da indústria processadora de alimentos e fibras. A justificativa da escolha de empresas ligadas aos sistemas agroindustriais deve-se ao envolvimento e familiaridade do autor com pesquisas em empresas deste setor e pela importância

7 GOLDBERG, R.A . Agribusiness Coordination: A Systems Approach to the Wheat, Soybean and Florida Oranges Economies. Graduate School of Business and Administration. Harvard University, 1968. In: ZYLBERSZTAJN, Decio \& NEVES, Marcos. F. (Coord.). Economia \& Gestāo dos Negócios Agroalimentares. São Paulo, ed. Pioneira, 2000. 
que o tema tem na indústria de alimentos. Foi realizado um estudo, de caráter qualitativo, com entrevistas em profundidade com executivos seniores de cinco empresas atuantes no sistema agroindustrial brasileiro, sendo quatro de capital nacional e uma de capital estrangeiro.

A empresas selecionadas são associadas ao Instituto Ethos, organização não -governamental que reune empresas que desenvolvem atividades de responsabilidade social no Brasil. O Instituto Ethos foi criado em julho de 1998, com o objetivo de apoiar as empresas na incorporação do conceito de responsabilidade social em seus modelos de gestão, e contava originalmente com 11 empresas. Este instituto reunia em 2001 cerca de 514 empresas, com faturamento conjunto equivalente a cerca de $27 \%$ do PIB brasileiro (Instituto Ethos, 2000).

Com base nessa delimitação do universo de pesquisa, foram levantadas evidências de como o tema da responsabilidade social é encarado por diferentes tipos de empresas de segmentos distintos dos sistemas agroindustriais.

\section{7 - AS QUESTÕES E HIPÓTESES DE PESQUISA}

De acordo com essa delimitação do universo da pesquisa, algumas questões e hipóteses em relação às várias dimensões da responsabilidade social corporativa poderão ser evidenciadas.

\subsection{1 - Questões de Pesquisa}

As questões de pesquisa, a serem tratadas visam a aprofundar 0 conhecimento da prática de responsabilidade social por parte do grupo de empresas selecionadas. 
- Classificação das ações de responsabilidade social desenvolvidas pelas empresas;

- Definição dos incentivos que levaram as empresas a investir em ações de responsabilidade social;

- Padrão de conduta das empresas concorrentes em relação às práticas de responsabilidade social;

- Identificação de possíveis critérios relativos a retorno econômico/financeiro para seleção das ações de responsabilidade social em que as empresas se engajam;

- Estimativa de valores (percentuais ou absolutos) de gastos em atividades de responsabilidade social;

- Estratégia de divulgação de suas ações de responsabilidade social;

- Mapeamento da estrutura organizacional para lidar com ações de responsabilidade social: direta, via fundações próprias ou via entidades parceiras;

- Identificação dos potenciais problemas, decorrentes do tipo de estrutura organizacional existente para lidar com atividades de responsabilidade social

\subsection{2 - Hipóteses de pesquisa}

Neste trabalho, a hipótese central é a de que o principal incentivo que leva as empresas a se engajar em atividades de responsabilidade social é a percepção de que este tipo de conduta leva ao aumento do capital reputacional e do valor da empresa no longo prazo. 
Desta hipótese central derivam algumas outras especificas:

Hipótese A - Empresas que atuam em mercados consumidores crescentemente exigentes - exportadoras de produtos agroalimentares tendem a ampliar o escopo da responsabilidade social para além das responsabilidades econômicas e legais, procurando desenvolver ações sociais/ambientais mais amplas entre as comunidades onde possuem bases produtivas;

Hipótese B - Empresas envolvidas em atividades potencialmente sujeitas a riscos de naturezas diversas desenvolvem ações de responsabilidade social além das de responsabilidades social e legal, pelos potenciais problemas ambientais e/ou sociais causados às comunidades;

Hipótese C - Empresas que buscam alavancar recursos no mercado de capitais desenvolvem ações de responsabilidade social além das de responsabilidades econômica e legal;

Hipótese D - Empresas multinacionais desenvolvem atividades de responsabilidade social nos diversos países onde operam, cada vez mais seguindo uma orientação estratégica da matriz.

Hipótese E - A operacionalização direta de projetos sociais pela própria estrutura organizacional da empresa ocorre quando existe elevado grau de especificidade entre a atividade de negócios e as ações de responsabilidade social a serem implementadas.

Hipótese F - A criação de uma estrutura "fora da firma", especializada em atividades sociais, reduz os custos de agência decorrentes do desalinhamento de interesses entre $\circ$ principal (acionista/sócio) e os agentes 
(executivos/gestores), no caso de empresas em que exista a separação de propriedade e controle.

As hipóteses não foram testadas formalmente. Entretanto, foi aprofundada a discussão em torno das motivações das empresas para adotar ações de responsabilidade social, a partir das evidências nas empresas analisadas. Esperase que o presente estudo possa servir de apoio para que futuros estudos formulem modelos que testem tais hipóteses. 
CAPÍTULO 2 - METODOLOGIA 


\section{1 - O TIPO DE PESQUISA}

$\mathrm{Na}$ primeira etapa deste trabalho foi realizada uma pesquisa para uma familiarização com o tema em questão e a sua sistematização. Esta etapa justificou-se, uma vez que $\circ$ objeto de pesquisa é relativamente recente. A abordagem exploratória, com base em dados primários e secundários, deu-se a partir de revisão bibliográfica, levantamento de informações e dados documentais em artigos de revistas especializadas, sites de internet, congressos e seminários, jornais, e entrevistas não estruturadas com agentes do setor.

A partir dessa primeira etapa, a abordagem exploratória foi aprofundada com um estudo multicasos. Esta pesquisa buscou um maior aprofundamento da temática da responsabilidade social corporativa, especificamente quanto às percepções dos empresários e executivos das empresas analisadas. Foram estabelecidas algumas evidências a partir das hipóteses e questões de pesquisa propostas. A carência de dados que permitam a utilização de modelos quantitativos é uma realidade inexorável característica do momento em que se desenvolveu a investigação.

\section{2- O MÉTODO DE PESQUISA}

\subsection{1 - O Método do Estudo de Casos Múltiplos}

A pesquisa foi desenvolvida pelo método de Estudos de Casos Múltiplos. A utilização de casos múltiplos permite o observação de evidências em diferentes contextos, pela replicação do fenômeno, sem necessariamente se considerar a lógica de amostragem (YIN, 1989).

O tipo proposto de pesquisa (qualitativa) é adequado a situações em que se deseja construir teorias, enquanto os métodos quantitativos se adequam ao processo de teste de teorias. Bonoma (1985) destaca que quando o objetivo é 
construir teorias, as evidências qualitativas permitem compreender mais profundamente o fenômeno, dentro do seu próprio contexto. Yin (op.cit.) destaca que questões do tipo "como" e "por que" apresentam natureza mais explanatória, não podendo ser tratadas simplesmente por dados quantitativos, enquanto questões do tipo "quem", "o que", e "onde" têm melhor tratamento com dados quantitativos.

Yin (op.cit.) destaca que o estudo de caso é um método potencial de pesquisa quando se deseja entender um fenômeno social complexo, pressupõe um maior nivel de detalhamento das relações entre os individuos $e$ as organizações, bem como dos intercâmbios que se processam com o meio ambiente nos quais estão inseridos. O foco temporal é outro elemento decisivo para a escolha do método. Yin (op.cit.) destaca o método de casos como o mais adequado ao estudo de eventos contemporâneos, e neste caso mais poderoso que a análise histórica.

Pettigrew (1985 apud LAZZARINI, 1997) ${ }^{8}$ destaca que novas linhas de pesquisa em ciências sociais têm procurado abordar aspectos gerais do problema em estudo, o que, por si só, exige uma abordagem mais contextual. Lazzarini (op.cit.) acrescenta que o estudo de caso é particularmente útil neste tipo de enfoque, pois o objetivo é contextualizar e aprofundar o estudo do problema, sem buscar determinar a incidência do fenômeno no seu universo.

Lazzarini (1997, p.21) ressalva, entretanto, que:

${ }^{8}$ PETTIGREW, A. M. Contextualist research: a natural way to link theory and practice. In: LAZZARINI, S.G. Estudos de Caso para Fins de Pesquisa: Aplicabilidade e Limitações do Método. In: FARINA et. al. (Coord). Estudos de Caso em Agribusiness. São Paulo: ed. Pioneira, p. 9-23, 1997. 
Tal compreensão, para fins de pesquisa, não deve ser buscada sem que haja retroalimentação de um corpo teórico que necessite de consolidação e/ou aperfeiçoamento. Assim sendo, o estudo de caso é particularmente aplicável quando se deseja obter generalizações analíticas, e não estatísticas, que possam contribuir para um certo referencial teórico. Sem este enfoque, o estudo de caso acaba tornando-se apenas uma história bem contada .

\subsection{2 - O Universo da pesquisa}

Foram realizadas entrevistas com acionistas e executivos de cinco empresas atuantes no sistema agroindustrial brasileiro, sendo quatro de capital nacional e uma de capital estrangeiro:

- Perdigão

- Sadia

- Grupo Orsa (Orsa Embalagem e Papel / Jari Celulose)

- Nestlé

As empresas selecionadas para as entrevistas atuam no setor de processamento e industrialização de alimentos (Perdigão, Nestlé e Sadia). Outras duas empresas (Orsa Celulose, Papel e Embalagens e Jari Celulose) pertencem a um mesmo grupo empresarial (Grupo Orsa), atuante nos segmentos de embalagem, papel e celulose.

A tabela 1 apresenta alguns dados relevantes sobre as empresas-foco da pesquisa qualitativa. 
Tabela 1 - Classificação das empresas selecionadas para pesquisa qualitativa - dados setoriais e gerais.

\begin{tabular}{c|c|c|c|c}
\hline Empresa & Setor & $\begin{array}{c}\text { Vendas em } \\
2000 \\
(U S \$ 000)\end{array}$ & $\begin{array}{c}\text { Controle acionário/ } \\
\text { Capital }\end{array}$ & $\begin{array}{c}\text { Posição no } \\
\text { ranking das } \\
500 \text { maiores } \\
\text { (em vendas) }\end{array}$ \\
\hline Perdigão & Alimentos & $1,037.9$ & $\begin{array}{c}\text { Fundo de } \\
\text { pensão/capital } \\
\text { aberto/Brasileiro }\end{array}$ & 54 \\
\hline Sadia & Alimentos & $1,740.6$ & $\begin{array}{c}\text { Familiar/capital } \\
\text { aberto/brasileiro }\end{array}$ & 32 \\
\hline Orsa & Embalagem e & 173.0 & $\begin{array}{c}\text { Familiar/capital } \\
\text { fechado/brasileiro }\end{array}$ & 419 \\
\hline Jari & Celulose & 179.3 & $\begin{array}{c}\text { Familiar/capital } \\
\text { fechado/brasileiro }\end{array}$ & 406 \\
\hline Nestlé & Alimentos & $2,574.8$ & $\begin{array}{c}\text { Capital } \\
\text { fechado/suíço }\end{array}$ & 20 \\
\hline
\end{tabular}

Fonte: Revista Exame - ed. Especial, 07/2001 - Maiores e Melhores.

\subsection{3 - Coleta, análise e tratamento de dados}

A coleta de dados da pesquisa foi realizada por meio de entrevistas pessoais com executivos seniores das empresas selecionadas, e o instrumento de pesquisa foi estruturado e não disfarçado, com questões abertas. A partir do roteiro de entrevistas, foram feitas análises não estatísticas, para o aprofundamento do objeto em estudo. 
Os estudos de caso exploram as percepções dos empresários e executivos sobre os de benefícios diretos ou indiretos para a empresa das ações de responsabilidade social .

A estrutura dos casos segue a seguinte seqüência:

\section{a) informações básicas:}

Neste item são descritas de forma genérica as principais características da empresa em questão: mercados, tipos de produtos, número de funcionários, unidades produtivas, concorrentes, entre outros.

\section{b) As atividades de responsabilidade social da empresa:}

Neste item são descritas a principais atividades de responsabilidade social desenvolvidas pelas empresas e suas motivações centrais.

\section{c) A Estrutura Organizacional para o desenvolvimento das acões sociais:}

Neste item discute-se a forma escolhida pela empresa para o desenvolvimento de ações de responsabilidade social: por meio de uma estrutura interna definida ou não, via uma organização específica (ex.Fundação) ou apenas por meio de parcerias ou doações.

\section{d) Evidências de retorno à imagem corporativa:}

Neste item são apresentadas as principais evidências de reconhecimento das ações das empresas, como premiações, títulos obtidos e selos. Discute-se também as percepções dos empresários e executivos sobre os impactos das ações da empresa para a reputação e a imagem corporativa, 
- impacto nas vendas, o relacionamento com funcionários, clientes, fornecedores e potenciais investidores.

Os estudos de casos analisados visam a evidenciar as hipóteses sugeridas neste trabalho, com base no referencial teórico da Nova Economia Institucional e especialmente resgatando a visão institucional de North (op.cit.). As mudanças institucionais que estão levando à intensificação do fluxo informacional e a internacionalização dos mercados têm induzido as empresas a desenvolverem ações para manter ou ganhar reputação, e a intensificarem sua preocupação com o comportamento ético e socialmente responsável.

A outra vertente do trabalho refere-se à forma como as empresas se estruturam para desenvolver atividades de responsabilidade social. Procurou-se embasar a definição da forma mais eficiente com base na Economia dos Custos de Transação (ECT) e na Teoria de Agência. Os cinco estudos de caso analisados evidenciam os condicionantes das ações sociais e do alinhamento de interesses entre os gestores das ações sociais (agentes) e os instituidores (principal). 


\section{CAPÍTULO 3 - REVISÃO DA LITERATURA.}

Se as instituições são as regras do jogo, organizações e seus empreendedores são os jogadores (NORTH 1994, p.361). 


\section{1 - O DEBATE DA EMPRESA SOCIALMENTE RESPONSÁVEL}

Bowen (1953, apud Maignan, 2001) ${ }^{9}$, tem sido reconhecido como o primeiro acadêmico a desenvolver um ensaio sobre o tema das responsabilidades corporativas, no qual salienta que as empresas devem seguir linhas de atuação que sejam desejáveis no que se refere aos objetivos e valores da sociedade na qual estão inseridas. Carroll (1979) avançou nesta temática, sugerindo que as atividades de negócios devem preencher quatro responsabilidades principais, em ordem decrescente de prioridade: econômicas, legais, éticas e filantrópicas.

A responsabilidade econômica envolve as obrigações da empresa de serem produtivas e rentáveis. Segundo Carroll (op.cit.): "A primeira e mais importante responsabilidade social da atividade de negócios é econômica por natureza. Antes de mais nada, a instituição de negócios é a unidade econômica básica de nossa sociedade".

A responsabilidade legal corresponde às expectativas da sociedade de que as empresas cumpram suas obrigações de acordo com o arcabouço legal existente. A responsabilidade ética refere-se às empresas que, dentro do contexto em que se inserem, tenham um comportamento apropriado de acordo com as expectativas existentes entre os agentes da sociedade. A responsabilidade filantrópica reflete $\circ$ desejo comum de que as empresas estejam ativamente envolvidas na melhoria do ambiente social. Esta última dimensão da responsabilidade social vai, portanto, além das funções básicas tradicionalmente esperadas da atividade empresarial. Esta dimensão poderia também ser considerada como uma extensão da dimensão ética.

${ }^{9}$ BOWEN, H. R. Social Responsibilities of the Businessman. In: MAIGNAN, Isabelle. Consumer's Perceptions of Corporate Social Responsibilities: A cross-cultural Comparison. Journal of Business Ethics. Netherlands: Kluwer Academic Publishers. v.30,: p. 57-72, 2001. 
Embora a definição de Empresa Socialmente Responsável possa parecer intuitivamente simples, existe uma grande complexidade em torno deste termo. A proposição de Carroll (op.cit.) de subdivisão da responsabilidade social nas dimensões econômica, legal, ética e filantrópica é um importante referencial para a operacionalização destas variáveis; entretanto, as fronteiras entre estas dimensões são extremamente tênues, e em muitas situações são sobrepostas.

Além disso, esses conceitos variam em função do ambiente institucional. $O$ que é considerado um comportamento ético ou socialmente responsável pode variar de forma significativa em função do ambiente institucional no qual as empresas se inserem, englobando a natureza e qualidade de suas relações com um conjunto mais amplo dos seus stakeholders atuais e com as futuras gerações.

Jones, M. (1999) sintetiza os argumentos que suportam ou vão contra as atividades de responsabilidade social das organizações, considerando aspectos ideológicos e pragmáticos:

a) Argumentos favoráveis às atividades de responsabilidade social das empresas:

Os argumentos que suportam as ações de responsabilidade social são baseados em aspectos éticos ou em instrumentos racionais.

Os argumentos éticos são derivados de princípios religiosos, referencial filosófico ou normas sociais prevalecentes (ANDREWS, apud JONES, M., 1999) ${ }^{10}$. Em síntese, estes argumentos sugerem que a firma deve se comportar de uma maneira socialmente responsável porque é moralmente correto agir assim. Possuem um forte componente normativo.

\footnotetext{
${ }^{10}$ ANDREWS, K. Ethics in Practice: Managing the Moral Corporation. In: JONES, Marc T. The Institutional Determinants of Social Responsibility. Journal of Business Ethics. Netherlands: Kluwer Academic Publishers. v. 20, p. 163-179, 1999.
} 
O argumento instrumental em favor da responsabilidade social é baseado em algum tipo de cálculo racional, segundo o qual o comportamento socialmente responsável beneficiará a empresa como um todo, ao menos no longo prazo (JONES, M. 1999). Fombrun (1996, 2000), Pava \& Krausz (1995 apud MILES \& COVIN ${ }^{11}$ salientam que agindo racionalmente a empresa pode minimizar riscos de perda de reputação e explorar oportunidades de criação de diferenciação em relação aos competidores menos "socialmente responsáveis".

\section{b) Argumentos contrários às atividades de responsabilidade social} das empresas

Os argumentos contra as ações de responsabilidade social são baseados na função institucional das organizações ou na perspectiva de direitos de propriedade.

O argumento contrário a essas ações baseado no conceito da função institucional (LEAVITT, 1958 apud JONES, M. 1999) ${ }^{12}$ assume que outras instituiçōes como o governo, sindicatos, igrejas, organizações civis existem para realizar o tipo de função requerida pela responsabilidade social. Outro ponto é que os gestores de empresas de mercado não possuem habilidades e/ou tempo para implementar ações de cunho público.

Esse argumento é fortemente sustentado na premissa do auto-interesse, de acordo com o qual a resultante para a sociedade seria melhor se as empresas se concentrassem na sua função-objetivo de gerar tanto lucro quanto possivel

"PAVA, Moses ; JOSUA Krausz. Corporate Responsibility and Financial Performance: The Paradox of Social Cost. In: MILES, Morgan ; COVIN, Jeffrey. Environmental Marketing: A Source of Reputational, Competitive and Financial Advantage. Netherlands: Kluwer Academic Publishers. Journal of Business Ethics, ed.23, p. 299-311, 2000.

${ }^{12}$ LEAVITT, T. The Dangers of Social Responsibility. In: JONES, Marc T. The Institutional Determinants of Social Responsibility. Journal of Business Ethics. Netherlands: Kluwer Academy Publishers. v. 20, p. 163-179, 1999. 
consoante as regras do jogo, numa economia de mercado livre e aberta. Caberia ao governo estabelecer os aspectos regulatórios, definindo as regras do jogo, para evitar os desvios relativos ao poder de monopólio e externalidades, entre outras disfunções da economia de mercado. Também ao governo caberia a alocação de recursos advindos de impostos e taxas gerados a partir da atividade econômica privada, visando à redistribuição de renda e alocação mais eficiente dos recursos para aspectos sociais.

O outro argumento contrário às atividades de responsabilidade social é baseado no direito de propriedade (FRIEDMAN, 1970), também enraizado na análise econômica neoclássica. Esta perspectiva mantém que os administradores não têm outro direito que não seja o de aumentar o valor do acionista. $O$ incentivo formal dado pelas organizações focaliza o desempenho no âmbito do mercado.

\section{Conforme Friedman (1962):}

Existe uma e apenas uma responsabilidade social da atividade de negócios - utilizar seus recursos e engajar-se em atividades delineadas para incrementar lucros tanto quanto possível dentro das regras do jogo, qual seja, engajar-se em mercado livre e competitivo sem fraudes.

Friedman enfatiza que poucas tendências podem minar tão completamente os fundamentos da nossa livre sociedade como a aceitação, pelos executivos das corporações, de outras responsabilidades sociais que não a de gerar tanto dinheiro quanto possível para seus acionistas. Outra forma de atuação seria uma violação das responsabilidades legais, morais e fiduciárias, e caracterizaria um conflito de agência.

O autor atenua a visão crítica quando o gestor e o proprietário são o mesmo indivíduo; neste caso não haveria conflito de agência, pois o gestor estará utilizando recursos "do próprio bolso". Entretanto, mesmo neste caso, existe o 
argumento de que, de alguma forma, podem estar sendo alocados custos adicionais aos funcionários e clientes:

A situação do proprietário-indivíduo é de certa forma diferente. Se ele age reduzindo retornos de sua empresa para exercitar sua responsabilidade social, ele está gastando seu próprio dinheiro, não de outros. Se ele deseja gastar seus recursos neste propósito é seu direito, e eu não posso ver nenhuma objeção para tanto. No processo, ele, também, pode impor custos aos funcionários ou consumidores. Entretanto, como é de longe menos provável que ele possa exercer poder monopolístico como uma grande corporação, tais efeitos tenderão a ser menores. (FRIEDMAN, 1970).

\section{c) A convergência dos argumentos pró e contra}

Certo \& Peter (1993) apresentam uma síntese das abordagens pró e contra o engajamento das empresas em atividades de responsabilidade social:

O ponto de vista clássico vê as empresas como entidades econômicas, enquanto o ponto de vista contemporâneo concebe as empresas como membros da sociedade. Embora as organizações de negócio exerçam claramente os dois papéis, o reconhecimento disso nem sempre responde à questão de como as companhias devem se envolver em atividades de responsabilidade social. Entretanto, em muitos casos, ambos os pontos de vista levam à mesma conclusão sobre o fato de uma empresa dever ou não se engajar em uma atividade dessa natureza em particular. Por exemplo, quando a atividade for exigida por lei, ambas as abordagens apoiam o envolvimento nela. E, em situações em que há lucro, ambas as abordagens apoiam o envolvimento na atividade.

Zylbersztajn (2000) analisa a relação cooperativa espontânea entre a organização e a sociedade, destacando as formas nas quais se enquadram as 
cooperações com entidades filantrópicas e as promoções sociais de diferentes naturezas:

Estas ações serão justificadas pela ótica maximizadora, sempre que a empresa beneficiar-se de um ambiente positivo de relacionamento social, que pode trazer resultados de imagem que redundem em acréscimo no valor da organização no longo prazo. Em outros casos podem significar um desvio entre as funções objetivo do acionista e do gerente, que acaba sucumbindo às pressões sociais locais, em detrimento dos interesses dos acionistas, o que configuraria um problema de agente - principal. Finalmente podem resultar de uma proposta dos acionistas que derivam utilidade a partir de uma postura socialmente positiva, valorizados pelos stakeholders.

Assim, considerando, num primeiro caso, a ótica maximizadora, a empresa teria ganhos econômicos pelo aumento de seu capital reputacional. No caso dos acionistas derivarem utilidade de ações sociais, mesmo sem ganhos econômicos, não haveria desalinhamento de interesses entre o agente e o principal. Apenas no caso de o tipo de ação social não implicar ganhos econômicos pelo aumento do capital reputacional, e também por não fazer parte da função-utilidade dos acionistas é que ocorreriam problemas de agência.

Quazi \& O'Brien (2000) propõem um modelo de duas dimensões para classificação das visões existentes sobre a responsabilidade social (Figura 2). 
Figura 2 - Modelo bidimensional de responsabilidade social corporativa (RSC)

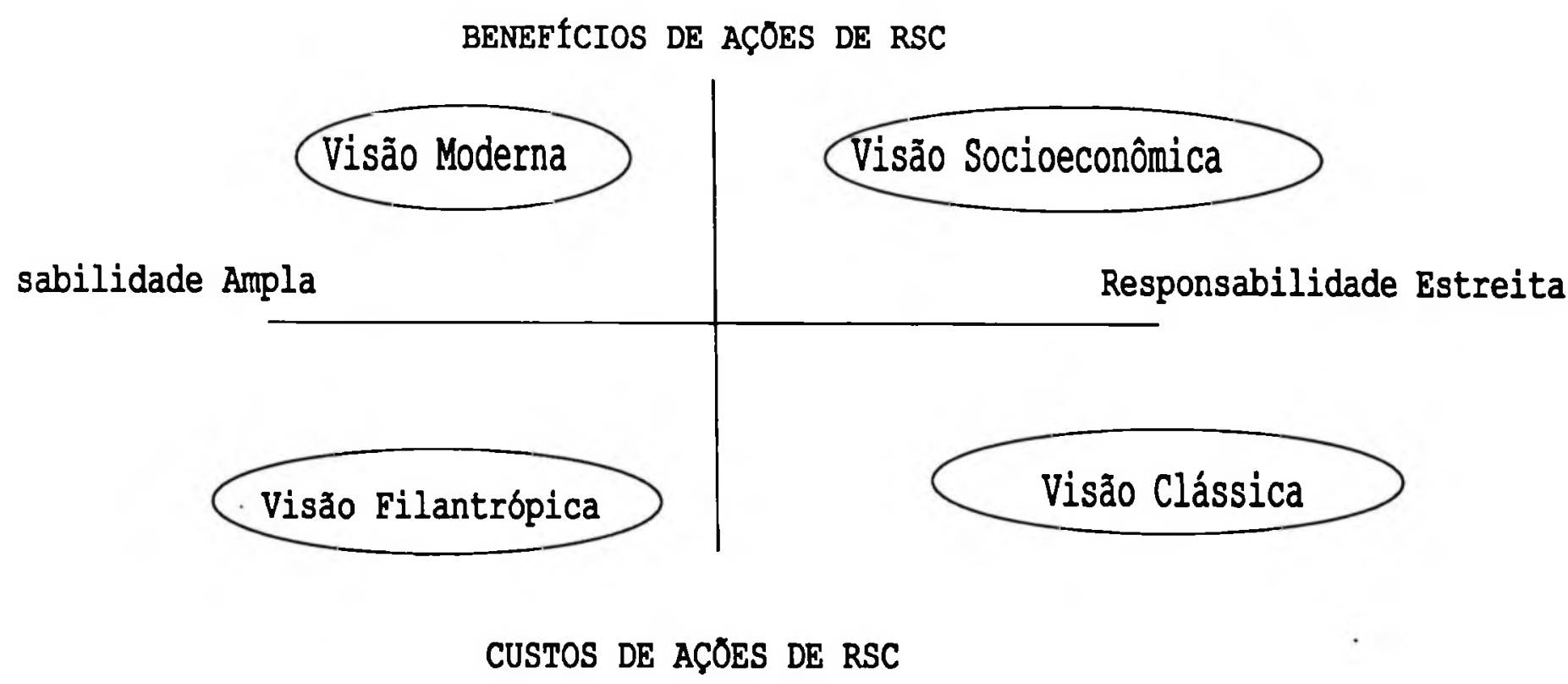

Fonte: Quazi \& O’Brien (2000).

Neste modelo; Quazi \& O'Brien (op.cit.), discernem duas vertentes da responsabilidade social: a responsabilidade ampla, que compreende as atividades de negócios que vão além das responsabilidades clássicas econômicas da empresa, e a responsabilidade estreita, segundo a qual a função-objetivo da empresa é basicamente a maximização do valor para o acionista, e a isto a empresa deve se ater.

A "responsabilidade ampla" se desdobra em dois tipos de visão: a visão que o autor denomina moderna, que seria aquela que acredita que no longo prazo as ações de responsabilidade social trazem benefícios para a empresa. A outra visão, denominada filantrópica, defende as ações de responsabilidade social mesmo que não tragam retornos para a empresa. Em síntese, a responsabilidade 
que o autor denomina ampla está em sintonia com a visão dos defensores das ações de responsabilidade social.

A "responsabilidade estreita" se desdobra também em duas visões: a visão socioeconômica que considera que a função-objetivo da empresa é a maximização do valor para o acionista, mas que as ações de responsabilidade social podem ajudar nesta geração de valor. A visão clássica, segundo o autor, defende que as ações de responsabilidade social não geram valor para a empresa, e não devem ser desenvolvidas.

Deve-se notar que a convergência em favor da responsabilidade social se dá entre as visões chamadas "moderna" e "socioeconômica". De acordo com estas duas visões, as ações de responsabilidade social estariam gerando valor para a empresa.

McWilliams e Siegel (2001) apresentam uma metodologia que propicia aos gestores determinarem o nivel apropriado de responsabilidade social a ser implementado pela corporação, baseando-se na teoria tradicional da firma, partindo da premissa de que os gestores devem buscar a maximização do valor da empresa. Nesta concepção, as ações de responsabilidade social seriam vistas como uma forma de investimento, que a corporação estaria fazendo no sentido de buscar a maximização do valor, assim como qualquer outro tradicional, como propaganda, $P \& D$ e treinamento.

Para maximizar lucros, a firma deveria oferecer precisamente aquele nivel de responsabilidade social para o qual o incremento da receita (advindo de um aumento de demanda) iguale o maior custo (da utilização de recursos para prover ações sociais). Fazendo isto, a firma encontra a demanda dos stakeholders relevantes, tanto daqueles que demandam ações de responsabilidade social (consultores, empregados, comunidade), como dos acionistas da firma (MCWILLIAMS e SIEGEL, op.cit.). 
$\mathrm{Na}$ visão desses autores, existiria um nível de investimento em responsabilidade social corporativa que maximizaria os lucros ao mesmo tempo em que estaria satisfazendo as demandas por atividades de responsabilidade social dos múltiplos stakeholders. O nível ideal de investimentos em responsabilidade social seria determinado por uma análise de custo-benefício.

\subsection{1 - Ética e responsabilidade social}

"Despite considerable effort by some of history's best minds, there is no consensus as to which behaviours are ethical and which are unethical".

Brickley, Smith e Zimmerman, 2000

Para B. de Holanda (apud Zylbersztajn, 2000) ${ }^{13}$, "Ética é definida como o estudo dos juízos de apreciação que se referem à conduta humana suscetivel de qualificação do ponto de vista do bem e do mal, seja relativamente a determinada sociedade, seja de modo absoluto".

Francesco e Gold (1998) consideram que a ética é um padrão moral não governado por lei que focaliza as conseqüências humanas das ações. Hartmann (2000) enfatiza que a ética freqüentemente requer um comportamento que atinja padrões mais altos que os estabelecidos por lei, acima de um comportamento baseado em ações calculadas, para produzir um benefício tangivel.

O campo da ética incorpora teorias que enfatizam diferentes stakeholders. Estas teorias podem gerar potencialmente interpretações conflituosas do que seria

13 BUARQUe DE HOLANDA, F. Novo Dicionário da Língua Portuguesa. Ed. Nova Fronteira, 1975. In: ZYLBERSZTAJN, Decio. A Organização Ética: um ensaio sobre as relaçães entre ambiente económico e o comportamento das organizações. Working Paper. texto base de aula de erudição para obtenção do título de professor titular. São Paulo, . São Paulo, Faculdade de Economia, Administração e Contabilidade/USP, 2000. 
ético ou antiético. Shaw (1999) destaca dois tipos de teorias sobre a ética: a conseqüêncialista e a não conseqüêncialista, ambas normativas.

A visão conseqüêncialista sugere que a avaliação moral de uma ação está ligada aos resultados que a ação produz, irá produzir ou intenciona produzir.

A visão não conseqüêncialista sugere que é a natureza do ato que importa, não o resultado. Tal visão propõe, por exemplo, que a quebra de uma promessa é errada, independentemente das conseqüências que resultam da quebra da promessa.

Na visão conseqüêncialista, algumas categorias diferem, especialmente as relacionadas com o resultado final (conseqüências para quem?). Shaw distingue duas categorias: egoísmo e utilitarismo. A primeira categoria diz respeito à busca do interesse individual como princípio-guia: "A visão egoísta considera que um ato é moralmente correto se e somente se ele promove o interesse de longo prazo do agente". (SHAW, 1999, p.46).

A categoria utilitarista advoga que todos os afetados pela ação ou decisão devem ser levados em conta: "utilitarismo é a doutrina moral segundo a qual deve-se sempre agir para produzir o melhor balanço possível do bem sobre o mal, para todos afetados pela ação" (SHAW, 1999, p.49).

Beekun et al. (2001) resumem que, de acordo com a categoria utilitarista, uma ação é ética se resulta em maior benefício ou bem para um número maior de pessoas. Os direitos e as responsabilidades individuais são ignorados em favor dos direitos e das responsabilidades coletivas: Utilitarianism has long been associated with social improvement and the promotion of actions that are in the interest of the community. Actions are right if they promote the greatest human welfare" .

Sen (1999, p.31) desenvolve uma consistente crítica da polarização entre egoísmo e utilitarismo: 
A tradicional dicotomia entre egoismo e utilitarismo é enganosa em vários aspectos, inclusive no fato de os grupos que atuam como intermediários entre o indivíduo e o todo - como classe, comunidade ou grupos ocupacionais - fornecerem o enfoque para muitas ações que envolvem comportamento com comprometimento (commited behaviour). Os membros de cada grupo podem ter interesses que são em parte convergentes e em parte conflitantes. As ações baseadas na lealdade ao grupo podem implicar, em alguns aspectos, um sacrificio de interesses puramente pessoais, assim como podem também facilitar, em outros aspectos, maior realização do auto-interesse.

É interessante notar, com base na argumentação de Sen, que muitas vezes a lealdade de grupo diz respeito à realização do auto-interesse, mas freqüentemente pode estar em conflito com interesses de outros agentes, fazendo emergir um outro tipo de dilema ético. Tome-se como exemplo uma situação de greve em um setor de atividade econômica essencial, como o setor de saúde pública. Num certo sentido, a lealdade e sua ação coletiva relaciona-se com a busca do auto-interesse deste grupo, podendo causar sérias externalidades a outros indivíduos. Até que ponto a busca do auto-interesse em uma situação como a descrita acima caracteriza um dilema ético? E se um indivíduo do grupo rompe a lealdade com seus pares e não participa da greve? Está sendo antiético? Com relação a quem?

Os conflitos éticos podem ser de dois tipos: problemas éticos e dilemas éticos.

O problema ético ocorre quando o indivíduo não quer fazer aquilo que julga correto. O dilema ético ocorre quando qualquer decisão a ser tomada pelo indivíduo irá violar importantes questões éticas (DIENHART, 2000). O exemplo anterior pode ser caracterizado claramente como um dilema ético, pois qualquer ação do indivíduo estará ferindo interesses de outros, sejam os membros do seu grupo, sejam os indivíduos afetados pelo movimento grevista. 
Tais argumentos e exemplos já demonstram em si a complexidade do tema ético. Adicionalmente, se o próprio conceito de ética é complexo quando aplicado ao comportamento do indivíduo, esta questão se torna ainda mais complexa quando se trata da questão ética das organizações. Brickley et.al.(2000, p.4), resumem da seguinte forma:

Uma corporação é, acima de tudo, simplesmente um conjunto de individuos. Ou mais precisamente, um conjunto de contratos (explícitos e implícitos) que colocam juntos indivíduos com interesses diferentes, freqüentemente conflitantes. Neste sentido, as organizações não se comportam de forma ética ou antiética, mas sim os indivíduos.

Segundo Zylbersztajn (2000):

...há controvérsias no tratamento dado ao tema, tanto pelo relativismo associado ao conceito do que vem a ser considerado ético, como também pelo tratamento dado pelos economistas, cientistas das organizaçōes e outros profissionais que atuam com o tema. $O$ relativismo ético implica que padrões culturais influenciam as escolhas dos indivíduos na sociedade, de tal modo que padrōes aceitos por determinadas culturas podem ser execrados por outras.

Por exemplo, a preocupação com o meio ambiente, em determinados paises, pode ser um fator muito mais restritivo do que em outros, que seriam mais permissivos a este respeito. O mesmo vale para a aceitação de produtos de empresas que se utilizam de mão-de-obra infantil. A conduta das empresas nas suas práticas comerciais, na relação com o governo, instituições financeiras, fornecedores e consumidores ou clientes pode variar significativamente, em função do ambiente institucional no qual a empresa opera. ${ }^{14}$

\footnotetext{
14 Segundo Ribeiro (2002, p.21) : "A ética trata de valores. A ciência não tem como prová-los, até porque faz parte do cerne deles que sejam plurais e frágeis. Sāo plurais, porque valores diferentes e mesmo opostos são igualmente legítimos. São frágeis pela mesma razão: não há como afirmar seu caráter absoluto...afora alguns princlpios gerais, como o do respeito à pessoa do outro".
} 
Em alguns ambientes institucionais, os condicionantes competitivos para a atuação de forma socialmente responsável podem se tornar restritivos. 0 darwinismo econômico cria pressões nas empresas para a produção de bens desejados pelos consumidores ao menor custo possivel e com melhor qualidade. Conforme Brickley et. al.(2000, p.4): “...se as firmas adotam politicas que são ineficientes, a competição fará pressão sobre elas para se adaptarem. Se elas não conseguirem se adaptar, no longo prazo fecharão".

Por outro lado, o processo de integração dos mercados pode estar forçando as empresas a elevarem seus padrões de comportamento ético. As empresas multinacionais, por exemplo, enfrentam o desafio de comunicar os valores e práticas éticas a seus milhares de funcionários que trabalham em diferentes sistemas institucionais (culturais e legais), em diferentes paises. Neste sentido, as diferenças na conduta ética em diferentes ambientes institucionais podem estar se reduzindo, especialmente nas empresas mais expostas à economia global. A economia globalizada, com redes interconectadas, levam as empresas a agirem desta forma, pois os riscos de sofrerem sanções legais e perdas de reputação crescem.

Conforme destaca Zylbersztajn (op.cit.):

...a ética nas organizações tem marcada a sua importância, ao vermos o crescimento e transnacionalização das organizaçōes, a ruptura do conceito tradicional de organização com o crescimento de relações de longo prazo entre firmas e a integração de mercados que induz a que decisões corporativas transcendam as fronteiras políticas e culturais dos paises.

\subsection{2 - O Enfoque Legalista e a Ética}

As leis são parte do ambiente institucional e afetam o comportamento das atividades de negócios de várias formas. Muitas relações contratuais são 
baseadas na prática institucional da "promessa". As leis contratuais, segundo Dienhart (2000), são necessárias sob dois aspectos: primeiro, proporcionam um contexto que faz com que as "promessas complexas sejam possiveis"; segundo, propiciam aos indivíduos incentivo para cumprir seus contratos, mesmo quando não o queiram fazer.

Na definição de Carroll (1979), a responsabilidade social "legal" implica uma conduta da empresa consoante com as normas legais vigentes. Numa visão simplificada, para atender a este requisito os gestores das empresas socialmente responsáveis devem simplesmente seguir os preceitos legais, sem necessidade de exercer nenhuma ação discricionária (managerial discretion).

A definição de Carroll da responsabilidade legal é bastante simplificadora da realidade. A lei é moldada pelo ambiente institucional. $\mathrm{Na}$ visão de North (1994), é parte das regras do jogo. As empresas são os "jogadores", que atuam condicionados pelo ambiente institucional, mas também tentando influenciar o modelo vigente a seu favor, assim como os demais grupos de interesse na sociedade (consumidores, ambientalistas, sindicatos, entre outros).

Friedman (1970) salienta que o objetivo social apropriado para os executivos das corporações é obter tanto lucro quanto possível, desde que de acordo com as regras básicas da sociedade, tanto em termos legais como éticos. ${ }^{15}$

Ostas (2001) examina a noção de "lei" implícita na prescrição de Friedman, argumentando como tese central que a concepção de "lei" é algo "socialmente construído", servindo de forma limitada de guia para as ações dos executivos. Os executivos devem primeiro construir a sua própria visão legal antes de agir de uma maneira que possa ser considerada "socialmente responsável".

\footnotetext{
${ }^{15}$ Grifo adicionado.
} 
O argumento de Ostas é de que os autores que escrevem sobre o tema da responsabilidade social a adotam de maneira acrítica, com base numa perspectiva formalista, assumindo implicitamente que a "lei" incorpora um conjunto singular e bem definido de comandos, no qual as conseqüências legais das ações dos executivos são claras. $O$ executivo não tem poder discricionário real, devendo apenas "seguir a lei" para estar agindo de forma socialmente responsável. $O$ problema é que a lei é muito mais do que um conjunto de regras e exceções. Um enorme conjunto de variáveis interfere nas decisões legais. Conforme Ostas (op.cit., p.265):

O administrador é informado que o resultado de uma pendência legal depende, entre outras coisas, de como a corte intepreta a evolução das tendências legais, como resolve tensões e conflitos de regras legais e lou interpreta linguagem legislativa ambígua. Em tal contexto, a ação judicial discricionária se manifesta, e o julgamento do administrador também se torna inevitável.

Em conseqüência, a visão legal positivo-formalista não pode ser considerada como um efetivo guia prático para balizar as ações de responsabilidade social na sua dimensão legal. Em última análise, o poder discricionário dos gestores se torna necessário e, neste sentido, muitas decisões acabam ficando numa interface entre os aspectos éticos e os legais. Paine (1994) resume a relação entre as dimensões ética e legal:

Os administradores estariam enganados, entretanto, se considerassem apenas os aspectos legais como um meio adequado de direcionar o amplo escopo de questões éticas que emergem no dia a dia de suas atividades. Se é legal, é ético, é um slogan freqüentemente ouvido. Mas condutas que são adequadas do ponto de vista legal podem ser altamente problemáticas do ponto de vista ético. 
Por exemplo, uma empresa pode estar diante do dilema ético de vender em paises emergentes produtos já banidos em seu país de origem, sem incorrer em nenhum problema legal previsto pelas diferentes legislações sobre estas restrições. Este é um "problema ético" comum enfrentado por empresas do setor de agroquímicos ou farmacêuticos, e ilustra a dificuldade em simplificar e separar as dimensões éticas/legais da responsabilidade social.

Gianetti da Fonseca $(1994$, p.148) reafirma a intrínseca relação entre as dimensões ética e legal:

O ponto central é que a qualidade dos jogadores afeta a natureza e robustez das regras do jogo. Jogadores motivados pelo auto-interesse crasso não se contentam em perseguir seus objetivos dentro da ordem do mercado e jogar limpo o todo tempo: eles irão persistentemente tentar -- e muitas vezes conseguirão -- driblar as restrições que o mínimo legal do mercado define. E pior: quando a própria autoridade política - o juiz da partida - fraqueja ou adota o auto-interesse crasso como princípio de ação, o resultado é a total deturpação não só do andamento do jogo, mas do placar final medido em termos da eficiência produtiva e criação da riqueza. A lei sem suporte moral é letra morta. A falta de compromisso com a ética torna precária e incerta a vigência do mínimo legal do mercado. Muitas vezes ela acarreta $\circ$ seu completo desvirtuamento, com sérias conseqüências para o desempenho da economia. Mais do que isso, a tese do egoísmo ético revela-se um ponto de vista inadequado e deficiente mesmo na hipótese (generosa) de que as regras do jogo do sistema de mercado estejam dadas de antemão e não sejam violadas de forma sistemática pelos jogadores ou pelo juiz da partida.

Um outra dimensão do dilema legal/ético pode ser exemplificada por externalidades geradas pelas organizações em suas atividades de negócios, que requerem um marco regulatório por parte do Estado. Esta ação regulatória é necessária em muitos casos, pois a ação voluntária altruistica das empresas, em tais condições inviabilizam-se na prática. É o caso, por exemplo, de restriçōes e 
requisitos impostos às empresas relativos a aspectos ambientais. Dienhart (2000) exemplifica uma situação deste tipo, partindo do tradicional modelo da teoria dos jogos, conhecido como Dilema do Prisioneiro.

Este modelo é utilizado em situações onde o comportamento cooperativo resulta em minimizar as perdas para os agentes, mesmo que estas sejam maiores do que cada agente poderia obter dependendo da ação do outro agente. A questão interessante é que todos agem de forma subótima, para evitar uma perda maior ainda.

Para a aplicação deste modelo em uma situação de regulação de atividade de negócios, Dienhart (2000, p.200) ilustra com o seguinte exemplo: três empresas químicas em uma determinada região, cada uma poluindo igualmente o ambiente, e tendo custos, receitas, margens e participação de mercado basicamente similares. Cada empresa sabe que se todas atuarem em conjunto e reduzirem a poluição em grupo, evitarão regulamentações mais restritivas por parte do Estado. Neste caso, todas terão de elevar seus custos e reduzir suas receitas, mas nenhuma perderá fatia de mercado para as demais. Adicionalmente, nenhuma empresa tem como monitorar se as demais de fato cooperaram. Dado que cada empresa tem o incentivo de internalizar benefícios e externalizar custos, cada uma se sentirá incentivada a simular que reduz a poluição sem fazê-lo.

Suponha-se que a empresa $A$ resolva quebrar o acordo e não instalar os redutores, enquanto as empresas $B$ e $C$ os instalam. $A$ empresa $A$ terá menores custos. As empresas B e $C$ terão maiores custos e terão de aumentar preços, para obter uma certa compensação. Mesmo assim, a empresa A terá conquistado maior fatia de mercado, receita e lucros.

Dado que as empresas podem prever este tipo de comportamento das demais, não terão incentivos para a ação cooperativa, mesmo que fiquem expostas a ações regulatórias mais fortes do Estado. 
Por outro lado, supondo-se que uma das empresas, a A, resolva, por altruismo, voluntária e unilateralmente reduzir a sua emissão de poluentes, mesmo que não requisitado por lei, dois aspectos são restritivos: o primeiro é que mesmo que ela reduza essa emissão, isto poderá ter um efeito pequeno na redução geral da poluição ambiental, dado o aspecto inerentemente abrangente e sistêmico da poluição, considerando que as outras não a reduzam. O segundo aspecto traz um dilema ético: ao tomarem essa decisão, os gestores da empresa A poderiam estar reduzindo os ganhos de seus acionistas, aumentando preços para seus clientes, reduzindo as margens para seus fornecedores ou reduzindo salários de seus funcionários, reduzindo valor para parte de seus próprios stakeholders. A empresa A estaria em um tipico dilema ético pois a comunidade ou outros de seus stakeholders estarão sendo penalizados.

Como conclusão, a lei propicia, neste caso, um ambiente de negócios mais previsivel, reforçando valores econômicos e éticos num determinado arcabouço institucional. Este é um exemplo de como a dimensão legal do ambiente institucional pode contribuir para uma melhor ou pior performance econômica e ética dos agentes na sociedade, na concepção delineada por North (1994).

Os tópicos a seguir buscarão destacar as inter-relações entre os conceitos de reputação, ética e responsabilidade social corporativa, que afetam o valor de mercado das organizações no longo prazo, considerando a hipótese de que a conduta socialmente responsável compõe o capital social reputacional das empresas. Mostrarão também o potencial incentivo para as empresas agirem de maneira socialmente responsável, como no caso da poluição ambiental, o que poderia levar a empresa A do exemplo apresentado a agir de forma "altruistica"16, visando a evitar perdas reputacionais, mesmo sob o risco de as demais não agirem da mesma forma.

\footnotetext{
${ }^{16}$ O termo está em aspas, pois se discutirá se a ação da empresa A foi realmente altruistica ou calculada, pragmática.
} 


\section{2 - O CONCEITO DE REPUTAÇÃO}

"...usually the product of years of demonstrated superior competence, reputation is a fragile resource; it takes time to build, cannot be bought, and can be easily damaged"

Petrick et. al.,1999

Petrick et. al. (1999) consideram que a reputação pode ser vista como o produto de um processo competitivo no qual a firma sinaliza suas características distintas para o público (interno e externo à empresa), no sentido de maximizar o seu status moral e socioeconômico. O capital reputacional é aquela porção do valor de mercado da empresa que pode ser atribuída à percepção da firma como uma corporação de boa conduta no mercado.

Com a intensificação do processo de globalização, em muitas situações o fator determinante para a sobrevivência das empresas pode depender do desenvolvimento e sustentação de uma reputação favorável (GRAY \& BALMER, 1998; ANDRIOF \& MCINTOSH, 2001). Tal percepção começa a se manifestar tanto na comunidade empresarial como no meio acadêmico. Conforme destaca Teece (1998), a competência do conhecimento e outros recursos intangiveis têm emergido como fatores-chave da competitividade nas nações desenvolvidas.

Os ativos intangiveis tornam-se crescentemente a base de diferenciação entre muitos setores. Conseqüentemente, tem sido dada maior ênfase aos aspectos ligados à reputação, lealdade do consumidor e conhecimento tecnológico, entre outros. Ou seja, atualmente, dada a maior facilidade tecnológica e mercadológica de replicação de práticas e condutas, o fator de diferenciação para obtenção de vantagens competitivas passa a ser, em grande medida, a percepção do público sobre a reputação da empresa.

Em pesquisa realizada pela revista Chief Executive (WINKLEMAN, $M$. 1999) foi feita uma pergunta a um grupo de executivos (CEO's) de grandes empresas americanas: "Quão importante é a reputação de uma empresa para que ela atinja seus objetivos empresariais estratégicos? 
- "Muito importante" foi a resposta compartilhada por $96 \%$ dos presidentes de empresas que responderam à pesquisa patrocinada pela revista. Mais sintomática ainda é a questão de quão importante é na atividade de um presidente de empresa lidar com a reputação da sua organização. Dos respondentes, $62 \%$ afirmaram ser mais importante do que há cinco anos atrás, e $36 \%$ deram ao menos a mesma importância.

O que chama a atenção não é tanto a importância dada à reputação das empresas em si, o que é evidente, mas o fato de que cada vez mais uma maior parcela do esforço estratégico despendido pelos principais executivos está sendo direcionada para o gerenciamento da identidade corporativa e monitoramento da reputação de suas empresas, visando a mantê-la, conquistá-la ou reconquistá-la.

Outra questão da pesquisa foi relativa à percepção de uma reputação corporativa superior. A Tabela 2 sintetiza a percepção dos empresários consultados.

Tabela 2 - Percepção dos empresários sobre os benefícios de uma reputação corporativa superior

\begin{tabular}{l|c}
\hline Afirmações propostas & $\begin{array}{c}\text { Respostas afirmativas } \\
\text { dos empresários } \\
(\%)\end{array}$ \\
\hline Ajuda na venda de produtos e serviços & 77 \\
\hline Facilidade para atrair executivos melhores & 61 \\
\hline Melhora credibilidade em tempos de crise & 41 \\
\hline Menor rotatividade de funcionários & 28 \\
\hline Permite maior discriminação de preços & 23 \\
\hline Maior evolução no preço das ações da empresa & 12 \\
\hline Alvo preferencial para alianças estratégicas/fusões & 12 \\
\hline
\end{tabular}

Fonte: Chief Executive, abril, 1999. 
A preocupação dos empresários decorre da crescente exposição das empresas à opinião pública, pelos veículos de comunicação, que transmitem informações aos locais mais remotos em tempo real, ajudando a disseminar uma boa reputação ou a destruí-la em um curtíssimo periodo de tempo.

Zylbersztajn (2000 b) salienta que: "o empresário que desconsiderar o papel da reputação, num mercado exigente, poderá cometer erros irreparáveis". O autor sustenta que um dos mecanismos mais importantes de controle do oportunismo é o desenvolvimento da reputação, medida como o valor presente de um fluxo futuro de recursos advindos do valor da marca e da imagem pública.

Duarte \& Dias (apud ASHLEY et. al. 2002, p.83) ${ }^{17}$ destacam que a organização do tipo empresarial talvez seja a mais criticada entre as organizações da sociedade, elencando uma série de razões para tal afirmação:

- Nenhum outro tipo de organização está tão relacionado com o sistema econômico e com os problemas decorrentes de seu mau funcionamento;

- A empresa é vista como fonte de riquezas e criadora de tecnologia, elementos indispensáveis à solução dos problemas sociais;

- Muitos dos males que afligem a sociedade contemporânea têm vinculo facilmente perceptivel com as empresas: poluição, deterioração do meio ambiente, aumentos gananciosos de preços, más condições de trabalho e outros que the são atribuídos no todo ou em parte;

- É cada vez mais reconhecida sua força de pressão sobre o setor político, com empresas aparecendo, por exemplo, como beneficiárias de favorecimento ilícito à custa do interesse coletivo;

\footnotetext{
${ }^{17}$ DUARTE, Damasceno; DIAS, José M. Responsabilidade Social: a empresa hoje. In: ASHLEY, Patrícia (Coord). Ética e Responsabilidade Social nos Negócios. São Paulo: ed. Saraiva, 2002.
} 
- São notórios os abusos de determinadas empresas, que para aumentarem seus lucros não levam em consideração os interesses dos operários e da comunidade, praticam ou aceitam contrabando, fraude no faturamento, manipulação de balanços e sonegação de impostos. Tais comportamentos antiéticos não afetam apenas a empresa que os pratica: refletem-se em suas congêneres $e$, de certo modo, contribuem para aumentar a desconfiança em relação ao sistema de livre-empresa, favorecendo ideologias contrárias a ele.

Tais razōes denotam, embora com certo grau de exagero, o que parcela da sociedade pensa a respeito das organizações empresariais, e reforçam a preocupação com a construção e manutenção do capital reputacional corporativo.

Em essência, o capital reputacional de uma empresa é formado por várias dimensões que moldam a imagem de uma determinada corporação. Algumas mais evidentes são a própria qualidade dos produtos que a empresa oferece, os seus serviços agregados, as práticas comerciais com clientes, fornecedores, instituições de crédito, práticas internas de recursos humanos, capacidade de inovação tecnológica, entre outras. Estes são os fatores que tradicionalmente conferem boa reputação e trazem vantagens competitivas sustentáveis às empresas no longo prazo.

Diversos autores têm sugerido que o "capital social reputacional" da firma pode ter efeito nas vendas, disseminando a premissa de que o capital reputacional da firma afeta o seu valor de mercado, em razão da publicidade adversa. (JONES \& RUBIN, 1999). Os consumidores, funcionários e fornecedores tendem a punir firmas engajadas em práticas socialmente irresponsáveis. O efeito positivo da boa reputação social também é salientada. Chauvin e Hirschey (1994) apontam que : 
“...se os investidores acreditarem que consumidores irão preferir comprar bens e serviços de bons empregadores, isto pode refletir a estimativa do efeito que a reputação da empresa no mercado de trabalho pode ter nas vendas".

Schwartz (apud JONES e RUBIN) ${ }^{18}$ assinala que "ações que aprimoram a imagem pública de uma corporação podem de forma vantajosa mudar a curva de demanda para os produtos desta corporação".

Corning (1999) comenta que a gestão do capital reputacional é vital numa época em que a mídia detém tanta influência sobre consumidores, investidores e outros grupos de interesse, e que uma má campanha de mídia pode ter o poder de destruir o capital reputacional de uma organização. Como resultado, os departamentos de relações públicas das organizações têm se tornado crescentemente importantes especialmente em situações nas quais a empresa está sendo alvo de uma prolongada campanha negativa.

Na visão de Brickley et. al. (2000, p.2):

... a reputação da empresa para o comportamento ético, incluindo sua integridade percebida em lidar com clientes, fornecedores e outras partes, é parte do valor de seu nome (brand name capital); desta forma, isto é refletido em sua avaliação (assim como o capital humano individual é baseado em parte em sua reputação para o comportamento ético). Neste sentido, mercados privados propiciam potencialmente importantes incentivos para o comportamento ético, ao imporem custos em organizações e indivíduos que rompem padrões éticos estabelecidos.

Empresas que desenvolvem um comportamento socialmente questionável em seu meio, seja no sentido ético ou legal, intencionalmente ou não, podem atrair a atenção da mídia, que, por sua vez, pode causar danos irreversiveis à

${ }^{18}$ SCHWARTZ, R. A . Corporate Philanthropic Contributions. In: JONES, Kari ; RUBIN, Paul H. Effects of Harmful Environmental Events on Reputation Firms. working paper, Social Science 
empresa,comprometendo a sua própria sobrevivência, como em alguns eventos ligados à espoliação ambiental, exposição a riscos da comunidade circunvizinha, práticas lesivas aos funcionários, para citar alguns exemplos ${ }^{19}$. Por outro lado, as práticas sociais positivas podem obter o efeito contrário, chamando a atenção da opinião pública, dos clientes, consumidores e governo de maneira positiva.

Gibson (2000) exemplifica com o caso da empresa Jonhson \& Jonhnson, que em 1982 retirou 31 milhões de embalagens com cápsulas do remédio Tylenol do mercado, quando se descobriu que alguém havia sabotado a empresa injetando veneno (cianida) em algumas poucas caixas. A reação da empresa foi aberta, pública e custou mais de 50 milhões de dólares. Mas a empresa manteve o nome de seu produto, e reconquistou seu market share num curto período de tempo. Em 2002, a empresa figurava na sexta posição no ranking das empresas mais admiradas do mundo ("World's Most Admired Companies") - Revista Fortune (2002).

Os ativos intangíveis fazem parte da estratégia competitiva das empresas em um ambiente de mudanças globais. À medida em que a velocidade das aquisições de ativos tangiveis se acelera e o processo de produção se "padroniza" globalmente, as empresas que desejam sustentar uma vantagem competitiva distinta (diferenciação) devem proteger, explorar e aprimorar seus ativos intangiveis. Enquanto os recursos tangíveis são mais facilmente "imitáveis" pelos competidores, os recursos intangiveis de liderança e ativo reputacional são mais difíceis de serem substituídos ou imitados. Neste sentido, a gestão da identidade corporativa passa pelo gerenciamento corporativo de fatores tangíveis e intangíveis, visando a criar uma rede interligada de percepções sobre a imagem e reputação da empresa na mente do público, incluindo clientes, fornecedores, funcionários e a sociedade no seu sentido mais amplo.

Research Network Eletronic Library, abr., 1999. Disponivel em:

$<$ http://papers.ssrn.com.taf?abstract id 158849>. Acesso em: 03 set. 1999.

${ }^{19}$ O que levaria a empresa A, do capítulo anterior, a agir da forma como agiu, supostamente altruistica. 
Uma reputação favorável, por exemplo, pode comunicar aos consumidores/clientes a qualidade do mix de produtos da empresa, permitindo-lhe exercer preços premium por seus produtos e serviços. Neste mesmo sentido, a boa reputação pode fazer com que os funcionários da empresa tenham sua autoestima elevada, o que se traduz em maior produtividade, e ainda facilitar o acesso da empresa a condições melhores de crédito (GARBETT, 1988).

Fombrun (op.cit.) define a reputação corporativa como a "reação afetiva ou emocional liquida" (boa ou má, fraca ou forte) de clientes investidores, fornecedores, empregados e o público em geral diante do nome da empresa. A identidade corporativa é definida como o conjunto de princípios e valores dos gestores e funcionários da empresa.

No dia-a-dia da organização, a identidade corporativa aparece na forma das práticas administrativas empregadas nas relações internas e externas da empresa. Na nossa sociedade, baseada na linguagem, atribui-se nomes a tudo o que pode ser percebido ou reconhecido, para distinguir algo de outras coisas no mundo (TADELIS, 1999). O mesmo ocorre com as firmas. A partir do momento em que uma empresa se estabelece, passa a ser reconhecida pelo seu nome, que é unicamente associado a suas características e desempenho passado. $O$ nome, ou de fato, a reputação conferida por este nome é um bem intangível desta empresa. ${ }^{20}$ A empresa é reconhecida pelo seu nome e pelas suas apresentações, formando imagens mentais que levam à formação da reputação corporativa na percepção das pessoas, conforme ilustrado na figura 3:

\footnotetext{
${ }^{20}$ Os ativos intangiveis das empresas nāo estāo, em geral, visiveis no seu balanço, e seu valor é calculado somente por ocasiäo da venda da empresa, subtraindo-se o valor tangivel líquido do preço de venda. Este goodwill captura o valor dos ativos intangíveis, onde se inclui o valor da reputação da firma.
} 
Figura 3 -Interrelação entre identidade e reputação corporativa

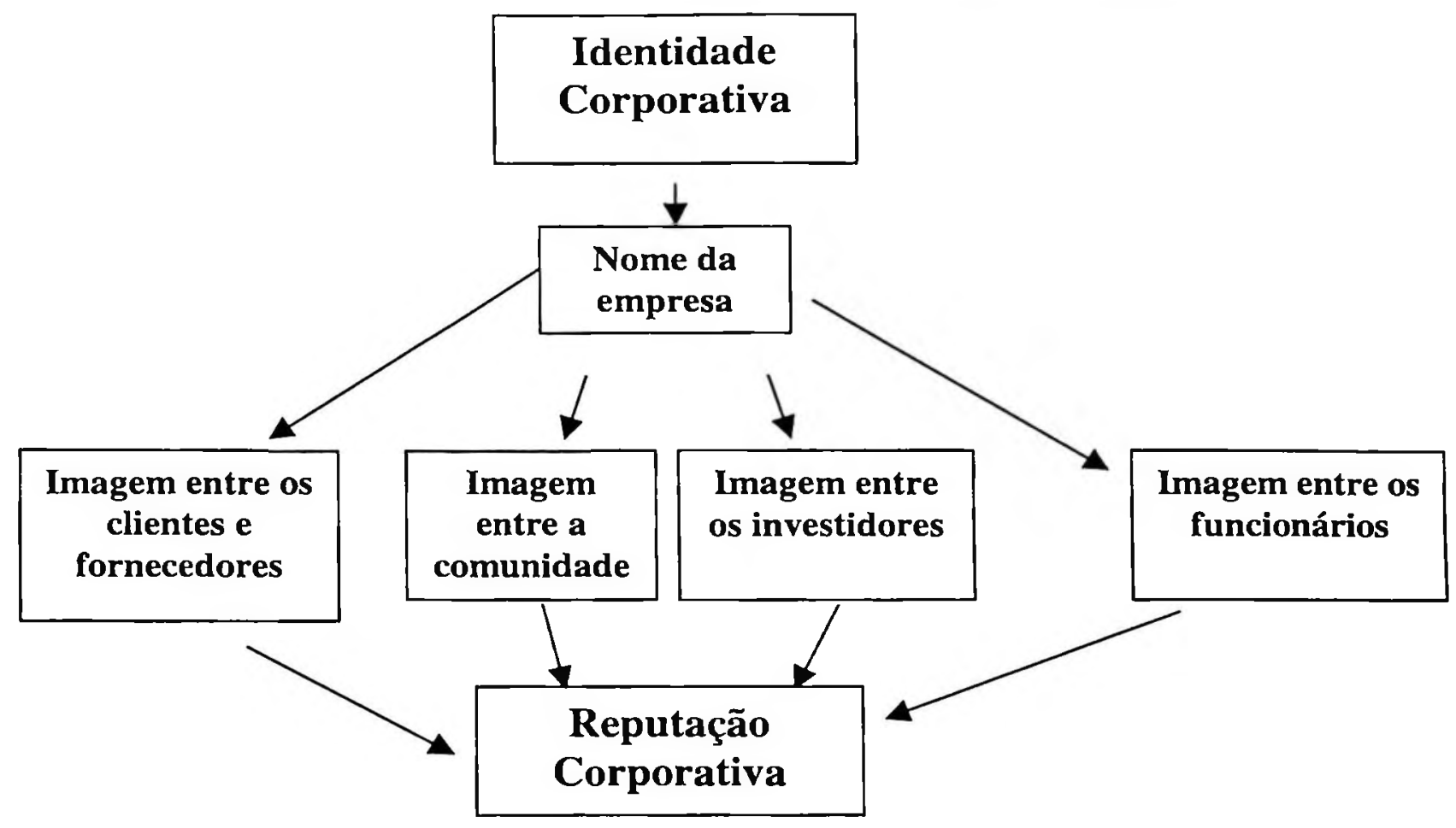

Fonte: Adaptado de Fombrun, 1996.

Os fatores que levam à construção da reputação, de acordo com Fombrun (op.cit.), podem ser agrupados em 4 constituintes: credibilidade, qualidade, responsabilidade e confiança. $O$ autor associa qualidade/confiabilidade aos consumidores/clientes, isto é, à percepção sobre os produtos e serviços oferecidos pela empresa.

A credibilidade está associada aos investidores e fornecedores, no cumprimento de contratos. A confiança está relacionada com o público interno constituinte da empresa, ou seja, com a sua percepção da solidez e integridade da empresa. A responsabilidade, finalmente, associa-se ao papel da empresa na comunidade em sentido mais amplo. A figura 4 ilustra as inter-relações entre os constituintes-chave. 
Figura 4 - Interrelações entre os constituintes chave da reputação

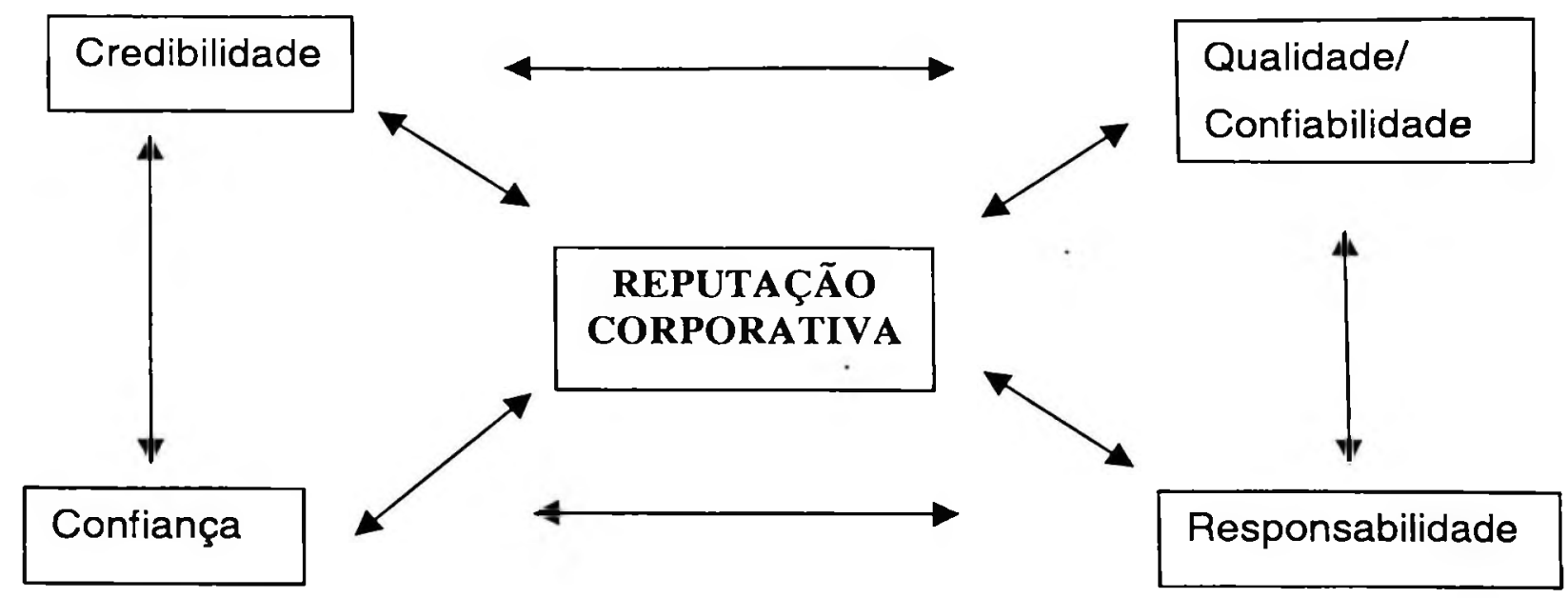

Fonte: Adaptado de Fombrun, 1996.

Embora Fombrun ofereça uma descrição operacional para analisar as interrelaçōes entre os diversos fatores constituintes da reputação, o autor não avança numa análise teórica mais aprofundada que explique o comportamento dos agentes nas suas práticas comerciais. Este referencial é importante para explicar em que situações a reputação é mais ou menos importante do ponto de vista estritamente econômico, análise da qual derivam possíveis comportamentos não éticos dos agentes. Assim, aspectos ligados à credibilidade, confiança e responsabilidade serão analisados com base em modelos da teoria dos jogos, economia dos custos de transação (ECT), teoria da agência e teoria dos stakeholders.

\subsection{1 - A Visão Econômica sobre a Reputação}

Our names are plainly printed on the bottled essence of our past behaviour Afterthoughts by Logan P.Smith, apud Tadelis, 1999.

Neste tópico será feita uma breve revisão dos pressupostos da Economia dos Custos de Transação (inserida dentro da vertente teórica da Nova Economia Institucional), como arcabouço para a discussão do efeito reputacional. É 
relevante para o presente trabalho o enfoque dado pela Economia dos Custos de Transação, pelo fato de esta relacionar as premissas do comportamento dos agentes (especialmente o oportunismo) com a eficiência das estruturas de governança que emergem, dado o sistema institucional vigente.

Os comentários de Zylbersztajn (2000) relacionam a questão da ética com o aspecto institucional e a conduta das empresas:

...mesmo se a solução da questão do relativismo ético pudesse ser alcançada partindo de um padrão cultural comum, cabe perguntar como se pode induzir as organizaçōes a adotarem determinados padrões éticos. Esta é a pergunta de central importância para os administradores e cientistas das organizaçōes em geral. Se comportamento não ético adiciona custos às transações, uma vez que a cooperação voluntária nem sempre é alcançada, quais são as prescrições que se pode fazer para mitigar o problema, seja na esfera privada ou pública? Como as sociedades, e dentro delas as organizações, podem incorporar princípios éticos, em última análise redutores de custos?

Um dos pressupostos comportamentais da Economia dos Custos de Transação, o oportunismo, assume características importantes para o presente trabalho. Instituições que minimizam comportamentos oportunistas agem, em muitas situações no sentido de minimizar comportamentos antiéticos e reduzir custos de transação entre os agentes econômicos.

\subsubsection{1 - Os Pressupostos comportamentais da Economia dos Custos de Transação (ECT)}

North (1994 afirma ter sido Ronald Coase $(1960)^{21}$ o primeiro cientista econômico a estabelecer as conexões entre instituições, custos de transação e

\footnotetext{
${ }^{21}$ COASE, Ronald.The Problem of Social Cost. In: NORTH, D.C. Custos de Transação, Instituições e Desempenho Econômico. Rio de Janeiro: Instituto Liberal, 1994.
} 
teoria neoclássica. Os resultados preconizados pela teoria neoclássica só são, na verdade, obtidos quando não existem custos para se transacionar. North aponta, no entanto, que ...quando é custoso transacionar, instituições importam ${ }^{22}$.

O pressuposto básico da Economia dos Custos de Transação é de que o funcionamento dos mercados tem custos, não considerados pela economia neoclássica, que ocorre em um ambiente sem custos associados ao funcionamento da economia. Arrow (apud Williamson 1985, p.8) ${ }^{23}$ define custos de transação num sentido amplo, como sendo "os custos do funcionamento do sistema econômico".

Williamson (1993), contrariamente aos pressupostos neoclássicos, aponta para a ficção do custo de transação igual a zero. Na sua definição, os custos de transação são:

Os custos ex-ante de preparar, negociar e salvaguardar um acordo bem como os custos ex-post dos ajustamentos e adaptações que resultam, quando a execução de um contrato é afetada por falhas, erros, omissões e alterações inesperadas. Em suma, são os custos de conduzir o sistema econômico.

Para North (1994), os custos de transação são definidos como aqueles relativos à especificação do que está sendo comercializado e à garantia de que os conseqüentes acordos sejam cumpridos. Nos mercados econômicos, o que se especifica (mede) são os atributos valoráveis dos bens e serviços transacionados ou a performance dos agentes. $O$ autor sustenta que os mercados econômicos são tipicamente imperfeitos e caracterizados por altos custos de transação.

\footnotetext{
${ }^{22}$ Texto do discurso de prêmio Nobel, publicado no periódico American Economic Review com o título Economic Performance Through Time (1994).

${ }^{23}$ ARROW Kenneth J. The organization of economic activity: Issues pertinent to the choice of market versus non market allocation. apud WILLIAMSON, Oliver E. The Economic Institutions of Capitalism. New York. Free Press, 1985.
} 
Assim, num contexto em que o comportamento dos indivíduos é caracterizado pela busca de maximização de riqueza (auto-interesse) e por informações assimétricas acerca dos atributos de um determinado bem que está sendo transacionado, os custos de transação emergem como determinantes críticos da performance econômica. Como conseqüência, as instituições, para serem efetivas, devem atuar especialmente no sentido de ressaltar as soluções cooperativas. Em relacão aos custos de transações, as instituições devem ter o papel de reduzir os custos de transação e de produção para que os ganhos potenciais envolvidos nas transações se realizem (NORTH, 1990).

Cabe fazer uma distinção entre as diferentes abordagens analíticas de North e Williamson, na caracterização de instituições e dos custos de transação. O primeiro trata as instituições de uma forma macroanalítica, como "as regras do jogo" que serão o arcabouço do ambiente institucional (environment institutions). Já Williamson trata as instituições num nível microanalítico, considerando os tipos de "instituições de governança" (governance institutions - mercados, formas híbridas e hierárquicas). A transação passa a ser a unidade de análise, e a eficácia dos diferentes modos de governança é analisada considerando a economia nos custos de transação.

Williamson não desconsidera a importância do ambiente institucional "macro", afirmando existirem grandes interdependências entre o ambiente institucional e as instituições de governança. Esse autor, porém, centra a sua análise nas instituições de governança, tomando o ambiente institucional como dado $^{24}$, buscando ajustar as formas de governança ao ambiente institucional, visando à redução dos custos de transação.

${ }^{24}$ WILLIAMSON (1996, p. 5): "I take the institutional environment as given and the institutions of governance are where the analytic action resides". 
A Economia dos Custos de Transação se baseia em dois pressupostos comportamentais básicos: racionalidade limitada e oportunismo. O pressuposto da racionalidade limitada fundamenta-se no fato de que, mesmo que $\circ$ agente econômico busque um comportamento otimizador, só o consegue de maneira limitada, em razão das limitações cognitivas existentes. Conforme Simon (apud Zylbersztajn, 1995) ${ }^{25}$ :

...os atores econômicos desejam ser racionais, mas apenas conseguem sê-lo de maneira limitada...racionalidade limitada resulta da condição de competência cognitiva limitada de receber, estocar, recuperar e processar a informação. Todos os contratos complexos são inevitavelmente incompletos devido à racionalidade limitada.

Desta forma, a racionalidade limitada traz conseqüências para os aspectos ex-post dos contratos, pois como nestes não são factíveis de serem previstas todas as possibilidades, podem ocorrer dificuldades, e com isto os custos de transação são afetados. Um contrato perfeito, conforme apontam Milgrom e Roberts (1992, p.127), especificaria precisamente o que cada parte faria em toda possível circunstância, bem como a distribuição dos custos e benefícios observados em cada contingência (incluindo aquelas em que os termos do contrato tenham sido violados), de forma que cada parte individualmente consideraria como solução ótima ater-se aos termos do contrato. Dada a racionalidade limitada, no entanto, esse contrato perfeito não se verifica no mundo real.

${ }^{25}$ SIMON, Herbert A. Administrative Behaviour. In: ZYLBERSZTAJN, Decio. Estruturas de Governança e Coordenação do Agribusiness : Uma aplicação da Nova Economia das Instituições. Tese de Livre Docência apresentada ao Departamento de Economia, Administração e Contabilidade/USP. São Paulo, 1995. 
Milgrom e Roberts (op.cit.) ressaltam ainda que mesmo que uma contingência possa, em tese, ser prevista e planejada, e que um arranjo contratual possa ser implementado, um dos lados pode ter informação privada antes de o contrato ser assinado, o que interfere na possibilidade de se alcançar um acordo maximizador de ganhos para as partes envolvidas.

Dado que a informação não é simetricamente distribuida aos agentes econômicos, que a busca de informações pressupõe custos e, além disto, que os agentes têm também maiores ou menores oportunidades de acessar estas informações, surgem as possibilidades de açōes oportunísticas decorrentes da assimetria informacional que ocorre nas transações.

Note-se que o custo de informação pode ou não constituir um custo de transação, pois é possível ocorrer o custo da obtenção de determinada informação mesmo sem a efetivação da transação. No entanto, ocorrendo a transação, com CT > 0, estará implícito um certo custo de informação.

Para Williamson (1985), oportunismo é a busca do auto-interesse com avidez. A ECT trata o oportunismo como uma possibilidade, isto é, mesmo que parte dos indivíduos, ou mesmo a maioria, não tenha comportamento oportunista, a possibilidade de alguns poucos agirem oportunisticamente uma vez ou outra já é condição suficiente para que as transações fiquem expostas a estas ações, e passem a necessitar, portanto, salvaguardas e monitoramento, gerando assim custos de transação.

Conforme apresentado por Zylbersztajn (1995): 
Oportunismo é o outro pressuposto comportamental, sendo um conceito que resulta da ação dos individuos na busca do autointeresse. Entretanto o auto-interesse pode ser buscado de maneira não-oportunista. Oportunismo parte de um princípio de jogo nãocooperativo, no qual a informação que um agente possa ter sobre a realidade não acessível a outro agente pode permitir que o primeiro desfrute de algum benefício do tipo monopolístico.

A assimetria de informaçōes pode levar a comportamentos oportunistas ex post (risco moral) ou ex ante (seleção adversa) na transação.

A seleção adversa ocorre quando uma das partes age oportunisticamente ex-ante em relação à transação, por deter informação exclusiva. Ou, visto de outra forma, a assimetria de informaçōes seleciona adversamente os produtos que chegam ao mercado. Akerlof (1970) afirma que em algumas situações de assimetrias informacionais entre compradores e vendedores, benefícios mútuos do comércio podem ser obscurecidos pela perspectiva da "trapaça"26.

O autor descreve como a assimetria informacional pode levar à falência do mercado. Neste modelo, a menos que os vendedores estejam aptos a sinalizar de maneira crivel a qualidade de seus produtos, os compradores não estarão dispostos a pagar mais do que a média do mercado. Assim, os vendedores de produtos de mais alta qualidade não estão dispostos a oferecer seus produtos, deixando no mercado apenas os produtos de menor qualidade.

Para ilustrar sua aplicação, Akerlof oferece o exemplo do mercado de carros usados, em que o vendedor detém muito mais informações sobre o histórico do veículo do que o comprador ${ }^{27}$. O vendedor possui informação

\footnotetext{
${ }^{26}$ A palavra trapaça está sendo empregada neste contexto como tradução do termo cheating.

27 O autor dá como exemplo clássico o mercado de carros usados. Este modelo clássico é conhecido na literatura como market for lemons.
} 
privada sobre o bem. Esta fonte de ineficiência, definida como seleção adversa, representa que a oferta dos carros oferecidos no mercado é determinada de uma maneira que é adversa ao interesse do comprador (MILGROM e ROBERTS 1992, p.129). O potencial comprador, neste exemplo, poderá questionar sobre qual o motivo que levaria o vendedor a colocar à venda o automóvel, se este fosse confiável.

Neste exemplo, a existência de carros usados de baixa qualidade faz com que o preço dos carros de alta qualidade seja menor do que poderia ser caso não houvesse informação assimétrica e $\circ$ preço de carros de baixa qualidade fosse maior do que deveria ser. A tendência é de que passem a prevalecer sucessivamente no mercado os carros de baixa qualidade, forçando os preços para baixo. No limite, o preço de mercado estaria tão baixo que não motivaria os vendedores de carros de alta qualidade a ofertarem seus produtos no mercado. No entanto, o mercado alcançará o equilíbrio com um determinado preço que estará incluindo ao menos certa quantidade de carros de alta qualidade.

Entretanto, a fração dos automóveis de alta qualidade será menor do que na situação em que os consumidores fossem capazes de identificar sua qualidade antes de efetuar a aquisição. Esta é a razão pela qual poderíamos esperar vender nosso automóvel novinho, que sabemos estar em perfeitas condições, por um valor muito inferior ao originalmente pago por ele. Pelo fato de existir informação assimétrica, as mercadorias de baixa qualidade eliminam as de alta qualidade no mercado. Pindyck \& Rubinfeld (1994, p.805).

Outro exemplo é o seguro-saúde (WILLIAMSON 1985; MILGROM \& ROBERTS 1992). O grupo de pessoas que compram este tipo de seguro não é uma amostra randômica da população, mas um grupo de pessoas com 
informação privada sobre sua própria situação pessoal. Sendo assim, o segurado pode esconder informações relativas ao seu estado antes da formalização do contrato de saúde, para obter as vantagens do plano de seguro.

O risco moral (moral hazard) ocorre quando uma ou mais partes de um relacionamento têm comportamento oportunista pós-contratual (ex-post) devido à assimetria na informação entre as partes. A minimização deste risco implica um aumento do custo de informação, que por sua vez, aumenta o custo de transação.

Para diferenciar os conceitos de risco moral e seleção adversa, Milgrom e Roberts (1992) apontam o exemplo da venda de carros novos com garantia estendida. No caso da seleção adversa, as pessoas que tenderiam a comprar um carro com garantia maior do que a normal, dada pelo fabricante, seriam justamente aquelas que fariam uso do veículo em situações mais desfavoráveis e, conseqüentemente, em situações de maiores riscos (é uma situação ex ante, pois o comprador detém informação privada do tipo de utilização que dará ao veículo). No entanto, podem ocorrer situações em que o indivíduo, ao comprar o veículo com garantia estendida, passará a zelar menos pela sua manutenção, para não incorrer em custos, sabedor de que o seu bem estará garantido. Neste caso, trata-se de um comportamento oportunista ex post (risco moral).

Os conceitos de seleção adversa e risco moral são importantes para o presente estudo, pois nas relações entre empresas e seus stakeholders a possibilidade de comportamento oportunista ex post ou ex ante é uma constante. O tópico seguinte irá abordar em maior profundidade a interrelação entre os conceitos de oportunismo, reputação e ambiente institucional. Em especial, serão discutidas as condições institucionais para que o comportamento oportunista possa ser minimizado, prevalecendo o comportamento ético. 


\subsubsection{2 - Comportamento oportunista e reputação}

Alguns fatores podem minimizar a possibilidade de açōes oportunísticas dos agentes. Por exemplo, em mercados que possuam um círculo restrito de agentes, o ambiente institucional em que se insere a transação pode atuar no sentido de inibir atitudes oportunísticas, sob pena de perda de reputação, dado o caráter recursivo das transações.

Tanto as instituições formais (leis e regras formais de conduta, formas de punição jurídica) como as instituições informais (regras informais de conduta, cultura, coerção dos grupos sociais às ações dos indivíduos) determinam a maior ou menor possibilidade de os agentes atuarem oportunisticamente e, neste sentido, ao minimizarem esta forma de atuação, minimizam os custos de transação.

Ou seja, as instituiçōes eficazes são aquelas que, de alguma forma, minimizam a possibilidade de ações oportunísticas entre agentes, minimizando custos de transação. Visto de outra forma, pode-se afirmar que em tais ambientes o comportamento socialmente responsável, nas dimensões éticas/ legais, possibilita que as empresas ganhem (ou não percam) reputação.

Uma das facetas da reputação está ligada ao comportamento dos agentes nas suas transações comerciais, e envolve por exemplo, as negociações entre uma determinada empresa e seus fornecedores ou clientes, entre outros stakeholders ligados diretamente à atividade de negócios. Kreps (1990) apud Williamson 1996$)^{28}$ baseia-se na teoria dos jogos para modelar o comportamento dos agentes envolvidos em uma negociação, tendo em vista a potencial perda de

\footnotetext{
${ }^{28}$ KREPS, David M. Corporate Culture and Economic Theory. In: WILLIAMNSON, Oliver. The Mechanisms of Governance. New York: Oxford University Press, 1996.
} 
ganhos futuros de uma má conduta versus os potenciais ganhos presentes desta mesma conduta, em 3 situações distintas:

1) Contratos recorrentes entre um comprador e um vendedor (não cambiáveis);

2) Contratos recorrentes entre uma série de compradores e um só vendedor;

3) Contratos recorrentes entre uma série de compradores e uma sucessão de vendedores.

O efeito reputacional neste modelo atenua 0 incentivo para o comportamento oportunista no comércio interfirmas, uma vez que os ganhos imediatos são suplantados pela perda de ganhos futuros, restringindo as empresas de se comportarem irresponsavelmente. Neste modelo, existe uma seqüência de duas movimentações em cada jogo.

Supondo-se dois tipos de agentes, A e B:

Numa primeira situação, A deve decidir arriscar-se a confiar em B ou não. Se a parte $A$ aceita confiar, então a parte $B$ irá decidir se abusará ou não da confiança de $A$. caso os ganhos imediatos de $B$ forem maximizados se $B$ abusar da confiança de A, e o jogo for apenas uma jogada, então B poderá abusar de A.

Entretanto, no modelo de jogadas repetitivas existe elevada probabilidade de cada ação ser seguida por outra, mudando a análise, fazendo com que o payoff seja tal que o ganho conjunto é maximizado pela solução confiar/honrar. Por exemplo, $A$ diz para $B$ que continuará confiando em $B$, na esperança de ter esta confiança honrada, mas que se em algum momento $B$ desonrar esta confiança, $A$ nunca mais confiará em B. Se B acreditar nesta afirmação e o jogo for repetitivo, 
haverá um reforço na solução honrar/confiar, pois a perda de ganhos futuros de B suplantará os eventuais ganhos imediatos com o abuso da confiança por parte deste.

O argumento pode ser estendido para o caso de uma seqüência de A's decidirem confiar ou não em um único $B$. Supondo-se que todos os $A$ 's conheçam os acontecimentos das jogadas passadas, e que todos os A's agirão de acordo com a regra de nunca mais confiarem em $B$ se $B$ quebrar a confiança, então também a situação honrar/confiar prevalecerá.

No caso de uma sucessão de B's, cada sucessor "compra" a reputação do antecessor. Se todos os B's tiverem honrado a confiança, então cada sucessor terá o incentivo de honrar a confiança, dado o capital reputacional que foi construído. Agir de outra forma destruiria o capital reputacional.

O modelo de Kreps, entretanto, contém uma série de premissas que 0 afastam do mundo real, na visão de Williamson (1996). A mais importante é a premissa da inexistência de assimetrias informacionais (A sabe qual ação $B$ tomou). Outro aspecto é quanto a capacidade cognitiva dos agentes, pois as pessoas podem ser a) imperfeitamente informadas; b) as informações podem ser imperfeitamente entendidas; c) a aquisição da informação pode ser impossivel ou cara (WILLIAMS apud Williamson, 1996, p.153) ${ }^{29}$.

Williamson (1996, p. 153-155) amplia a visão crítica do modelo do efeito reputacional, assinalando que mesmo em situações simples de jogadas repetitivas diversas circunstâncias devem ser ampliadas:

${ }^{29}$ WILLIAMS, Bernard. Formal Structure and Social Reality. In: WILLIAMSON, Oliver E. The Mechanisms of Governance. New York: Oxtord University Press, 1996. 
a) Comunicação: $A$ pode saber que foi enganado por $B$, mas em certas situações $A$ não tem condições acuradas e sem custos de transmitir esta informação. São os limites da linguagem.

b) "Esperteza": Se $A(n)$ se imaginar mais esperto que $A(n-1), A(n)$ pode tomar a experiência como uma negligência de $A(n-1)$ e impor mecanismos contratuais para $\mathrm{B}$ onde possam existir salvaguardas.

c) Perdão: Os sucessores de B podem pedir perdão pela ação de seu antecessor. O mecanismo do efeito reputacional perde força com o perdão.

d) Complexidade: Como a reputação pode ser encarada quando muitos indivíduos tomam decisões em cada uma das empresas em questão, e quando bens e serviços mudam a cada período?

e) "Empresas familiares e profissionais": Muitas firmas não são dirigidas pelo próprio proprietário, como no modelo de Kreps (owner operator). Qual a base para transferir o mecanismo reputacional do contexto de owner operator para grandes empresas de controle difuso?

f) Preocupações estratégicas: Se os A's são rivais, $A(n)$ pode revelar sua experiência com $B$ de maneira incompleta ou distorcida, para colocar os rivais em desvantagem.

Milgron, North e Weingast (apud Williamson 1996) ${ }^{30}$ vão além da formulação de Kreps, criando um modelo com muitos jogadores. Neste caso, a instituição de uma terceira parte ("tribunal de justiça") se justifica, pois o custo de manter todos os agentes informados tenderia a ser elevado. Os autores

${ }^{30}$ MILGROM, Paul; NORTH, Douglass, WEINGAST, Barry. The Role of Institution in the Revival of Trade. In: WILLIAMSON, Oliver, E. The Mechanisms of Governance. New York: Oxtord University Press, 1996. 
exemplificam a criação da instituição medieval da "Lei dos Mercadores" como forma de dirimir disputas e exercer punições. ${ }^{31}$

Nesta linha, Williamson contesta 0 argumento de Kreps de que tanto grandes como pequenas corporações agem por meio do mecanismo do efeito reputacional. Na visão de Kreps, o efeito reputacional faria com que o mercado pudesse ser a forma mais apropriada de governança. Na visão de Williamson, as limitações reais do mecanismo de efeito reputacional limitam, por sua vez, a visão de "governança espontânea", induzindo a formas hierárquicas de governança em certas situações.

Tadelis (1999, p.548-550) menciona o próprio fato de Kreps admitir a limitação do modelo pela existência de múltiplos equilíbrios. Existem muitas situações de equilíbrio em que a firma não é comprada, seu nome não tem valor, e assim nenhum ativo intangível deve ser preservado. Pode ocorrer também que as forças que levariam ao equilíbrio no qual os nomes são valorados sejam indeterminadas. Além disto, o horizonte deve ser infinito no modelo de Kreps (jogo com grande número de interações).

Outra observação de Tadelis é de que não existe contabilidade de como a reputação da firma, representada pelo seu nome, pode crescer ou decrescer de valor, como observado na realidade. A teoria de Kreps também não oferece resposta a práticas comuns como a "troca de nomes" ou os anúncios de novo controle acionário da empresa. No modelo de Kreps também assume-se que pessoas de boa conduta tendem a adquirir um bom "nome", com boa reputação. $O$ resultado, interpretado com base no conceito de seleção adversa (AKERLOF,

$31 . .$. 'the role of the judges in the system, far from being substitutes for the reputation mechanism, is to make reputation system more effective as a means of promoting honest trade" ..."the system of private judges is designed to promote private resolution of disputes and otherwise to transmit just enough information to the right people in the right circumstances to enable the reputation mechanism to function effectively for enforcement" ( MILGROM et. al. apud WILLIAMSON, 1996, p.152). 
1990), é que pessoas de boa conduta valorizam bons nomes mais do que pessoas de má conduta. Tadelis caracteriza este fato como reputation maintenance effect.

Entretanto, o autor sugere uma abordagem diferente: é mais fácil para pessoas de boa conduta construir o seu próprio nome, e por isso, valorizar menos os nomes existentes do que pessoas de má conduta, que não possuem tanta facilidade para construir boa reputação. $O$ autor caracteriza este fato como reputation start -up effect.

A despeito do modelo de Kreps possuir limitações que o afastam do mundo real - com todas as premissas em que se baseia e a excessiva simplificação da realidade - o mecanismo do efeito reputacional age no sentido proposto pelo autor em muitas situações, como ponderam seus próprios críticos (WILLIAMSON, 1996; TADELIS; 1999; MILGROM et. al.apud WILLIAMSON, 1996). Outro aspecto que pode ser introduzido na discussão é a possivel diminuição das assimetrias informacionais, pelo fato de as empresas estarem atualmente expostas ao escrutínio público em razão da ação abrangente dos meios de comunicação e de todos os seus recursos informacionais.

Assim, dada a abrangência das conseqüências de uma prática de quebra de confiança, pode-se observar que atualmente o mecanismo do efeito reputacional se aproxima mais do modelo de Kreps.

Jones e Rubin (1999) declaram que as definições de reputação na literatura e o conceito de efeito reputacional referem-se basicamente à reputação da firma no mercado de produtos, lidando com empregados ou fornecedores, e à reputação da administração no mercado de capitais ${ }^{32}$. Chauvin e James (1994) notam que

\footnotetext{
${ }^{32}$ SHAPIRO, Carl. Consumer Information, Product Quality and Seller Reputation. In: JONES, Kari ; RUBIN, Paul H. Effects of Harmful Environmental Events on Reputation Firms. working paper, Social Science Research Network Eletronic Library, abr., 1999. Disponivel em: < http://papers.ssrn.com.taf?abstract id158849>. Acesso em: 03 set.1999.
} 
em todos os trabalhos teóricos sobre a reputação, ela tem valor econômico porque melhora a eficiência dos mercados.

Os economistas têm procurado descrever e modelar os métodos envolvidos para mitigar o problema da assimetria informacional e do comportamento oportunista. Se uma firma se desvia de um comprometimento com a qualidade, os consumidores punem a firma com sua menor disposição de pagar pelo produto. $O$ valor presente líquido dos lucros futuros declinam $e$, conseqüentemente, o valor de mercado da empresa.

Em outro contexto, se a firma engana de alguma forma o seu fornecedor, por exemplo, terá provavelmente que incorrer em maiores custos para a obtenção de suprimento no futuro. Empresas que enganam seus funcionários podem ter que oferecer maiores salários ou prêmios para atrair futuros empregadoṣ num mercado de trabalho competitivo. Assim, a reputação pode ser considerada um custo de entrada de uma firma no mercado, em que subseqüentes lucros representam o valor presente do retorno do investimento em reputação e conduta ética.

Também com relação aos investidores, o envolvimento de uma empresa em um incidente negativo (por exemplo em aspectos ambientais) pode levá-los a reavaliar as suas crenças na capacidade da empresa em lidar com as perdas decorrentes. Além disto, os investidores podem avaliar a possibilidade de implementação de ações regulatórias mais fortes que poderiam afetar os lucros da empresa no futuro. Miles e Covin (2000, p.302) apresentam evidências da existência de uma correlação positiva entre a reputação, a performance ambiental e a performance financeira:

...firmas que tentam trapacear, não cumprindo com os regulamentos sāo frequentemente desmascaradas, seja pelos 
reguladores ou pela opiniāo pública, e são tipicamente forçadas a pagar multas e/ou sofrerem erosão de suas posições competitivas devido ao dano reputacional.

Jones e Rubin (1999) sintetizam as possiveis situações decorrentes do efeito reputacional, de acordo com o arcabouço teórico tradicional da abordagem da reputação:

1) Um incidente negativo pode resultar numa queda da reputação da firma para seus clientes, empregados ou fornecedores. Dependendo da natureza do acordo implícito, a perda da reputação pode ser resultante de:

- Um desvio do comportamento esperado;

- A revisão por parte dos consumidores, empregados ou fornecedores das estimativas de probabilidade de a firma ter trapaceado.

2) A firma também pode sofrer perda de valor de mercado se os eventos levam a um decréscimo da crença na capacidade de seus administradores por parte dos investidores. Este fato pode ser resultante de:

- Um aumento do risco percebido de futuros incidentes, e/ou

- Um aumento do risco percebido de crescentes regulações restritivas.

\subsubsection{3 - Efeito Reputacional e Confiança ${ }^{33}$}

Jones e Murrell (2001) sustentam que "confiança" é a reputação que a firma goza de ter um comportamento confiável. Neste sentido, ações de responsabilidade social podem ser indicadoras da confiabilidade da empresa. Conceitualizando confiança como a reputação da firma, Jones (1995) essencialmente estabelece que a indicação da responsabilidade social corporativa

\footnotetext{
${ }^{33}$ A palavra "confiança" está sendo empregada, neste contexto, como tradução do termo trust.
} 
aprimora a performance da firma: "A habilidade da firma em sinalizar sua reputação para um comportamento não oportunista (por meio de ações junto aos stakeholders) pode leva a uma melhoria de performance na atividade de negócios".

A explicação é de que se a responsabilidade social corporativa é um sinal do que é importante para a firma, então é razoável concluir que este sinal pode ser usado pelos vários agentes (funcionários, clientes, fornecedores, investidores e credores) para formar as impressões sobre os valores, crenças, direcionamento e conduta geral da firma.

Jones (1995) desenvolve um modelo que integra a teoria econômica e a ética, concluindo que firmas que conduzem negócios com os seus diversos stakeholders na base de "confiança" (trust) têm incentivos para demonstrar comprometimento com o comportamento ético. $O$ comportamento ético propiciará à firma uma vantagem competitiva, desde que que desenvolva relações duradouras e produtivas com estes stakeholders.

A consideração do conceito confiança como um fator benigno na relação entre agentes econômicos tem sido alvo de críticas por diversos autores. Williamson(1996); Zylbersztajn e Zuurbier (1999) afirmam haver uma incorreta compreensão do que se pode chamar de "confiança" nas relações entre agentes econômicos.

Zylbersztajn e Zuurbier (op.cit.) declaram que o uso do conceito confiança não é determinado simplesmente por uma questão semântica, mas por sua relevância, pois pode evitar decisões estratégicas incorretas por parte das organizações. Williamson (1996) destaca como premissas a existência de racionalidade limitada (impossibilidade de os agentes em previrem todas as possíveis ocorrências em uma relação qualquer ao longo do tempo) e a possibilidade de existência de oportunismo, que levam a dificuldades contratuais 
no mundo real, demandando salvaguardas para permitir um longo termo na relação. O autor define três tipos de "confiança":

A confiança calculativa, relacionada a contratos que são baseados em salvaguardas de diferentes formas, facilmente confundida com a "confiança pura". Como exemplo de contratos desta natureza citam-se aqueles baseados na reputação, que pode impor perdas aos agentes no caso de ações oportunistas, em razão de a redução de ganhos futuros que superar os eventuais ganhos presentes da ação oportunista. Neste sentido, os agentes tenderiam a agir de maneira nãooportunista, não por razões benevolentes (cooperação benigna), mas em virtude de uma avaliação calculada das perdas e ganhos decorrentes do tipo de ação a ser empreendida. É basicamente respaldada pelo modelo de Kreps ("efeito reputacional').

A confiança institucional é outra categoria proposta por Williamson (op.cit.), de acordo com a qual o agente terá confiança no cumprimento do contrato mesmo na presença de oportunismo e racionalidade limitada. Os agentes não incorrerão em comportamento oportunista pois considerarão os custos das punições impostas pelo ambiente institucional tanto formal (aspectos legais) como informal (coerção social| ${ }^{34}$ ).

O terceiro conceito é o da confiança pessoal ou confiança pura, que é aquela condição na qual o agente irá expressar a confiança no cumprimento contratual mesmo na presença de racionalidade limitada e oportunismo, o que, na visão dos autores citados, é uma situação utópica nas relaçōes de negócio. ${ }^{35}$

\footnotetext{
34 Ocorre especialmente em close knit groups, comunidades com fortes caracteristicas culturais que condicionam o tipo de comportamento dos individuos, e fortes sanções no caso de açōes consideradas inadequadas pelas regras do grupo.

35 "the world of commerce is reorganizaded in favor of cynics, as against the innocents, when social scientists emply user friendly language that is descriptively accurate - since only innocents are taken in". (WILLIAMSON, apud ZYLBERSZTAJN e ZUURBIER, 1999, p.2).
} 
Em síntese, especialmente no caso da "confiança calculativa", o efeito reputacional é um dos condicionantes básicos da relação entre os agentes. Milgrom e Roberts (1992) destacam ainda que os efeitos reputacionais serão magnificados pela disseminação da informação entre diferentes agentes, mesmo entre aqueles não participantes da transação em questão.

\subsubsection{4 - A Filantropia Corporativa e os Ganhos de Reputação}

"Historically, economists have tended to ignore private philanthropic behaviour and to regard it as economically irrational'. Schwartz (1968, p.479)

O modelo de Kreps e a discussão crítica acerca do mecanismo do efeito reputacional estão centrados na dimensão das relações de troca entre agentes no mercado. Ou seja, a dimensão do efeito reputacional baseia-se no comportamento dos agentes em relação, essencialmente, às suas práticas comerciais.

O exercício das ações sociais de filantropia vai além do compromisso estritamente econômico/ético/legal das organizações. Quando uma corporação se engaja na filantropia, está confrontando-se com a necessidade de alocar recursos para atividades que não estão diretamente relacionadas com os objetivos de negócios imediatos. Este tipo de ação de responsabilidade social pode ser encarado sob três aspectos:

a) Estas ações podem advir dos valores dos seus acionistas, que, independentemente dos possiveis retornos que as ações possam trazer para as atividades principais, entendem que a empresa deve engajar-se em práticas sociais;

b) As ações podem ser determinadas por de uma visão pragmática, segundo a qual de alguma forma estas ações podem trazer retornos para a empresa, sendo, neste caso, uma estratégia de busca de valor (value seeking) por parte da organização. 
c)

As ações podem derivar de gestores que vêem nesta prática uma forma de obter ganhos pessoais, poder, autoridade na comunidade local, independentemente de haver ou não alinhamento com os interesses dos acionistas.

A alternativa (a) parte da visão de que não é unicamente o auto-interesse que rege os seres humanos. É uma visão benigna da atuação da empresa na sociedade. A alternativa (b) parte do pressuposto de que o "capital social reputacional' das empresas tende a crescer com ações sociais, demonstração de preocupação ecológica e com os impactos ambientais, ações de filantropia e outras formas de interação com a comunidade na qual a organização está inserida. Conforme argumento de Friedman (1970):

To ilustrate, it may well be in the long-run interest of a corporation that is a major employer in a small community to devote resources to providing amenities to that community or to improving its government. That may make it easier to attract desirable employees, it may reduce the wage bill or lessen losses from pilferage and sabotage or have other worthwile effects. Or it may be that, given the laws about the deductibility of corporate charitable contributions, the stockholders can contribute more to charities they favor by having the corporation make the gift than by doing it themselves, since they can in that way contribute an amount that would otherwise have been paid as corporate taxes.

A alternativa (c) constitui-se num problema de agência, pois existe desalinhamento de interesses entre o gestor e o principal.

Fombrun (2000) sintetiza que a atividade socialmente responsável ajuda a empresa a reforçar sua ligação com a comunidade local e com os empregados. Por outro lado, a construção do capital reputacional também melhora a habilidade 
de negociar contratos mais atrativos para a empresa com fornecedores e governo, além de em certas circunstâncias propiciar preços premium para os produtos da empresa e menores custos de capital. $O$ autor se refere especificamente às atividades de responsabilidade social filantrópicas como criadora ou mantenedora do capital reputacional sob dois aspectos: a) Criando vantagem competitiva, aprimorando a capacidade da empresa em atrair e manter recursos; b) Minimizando riscos de perdas reputacionaiș. $O$ modelo expresso na figura 5, baseado em Fombrun (2000), sintetiza a lógica do aumento de valor da empresa a partir de ações socialmente responsáveis.

\section{Figura 5 - O Modelo de criação de valor a partir de ações de Responsabilidade Social}

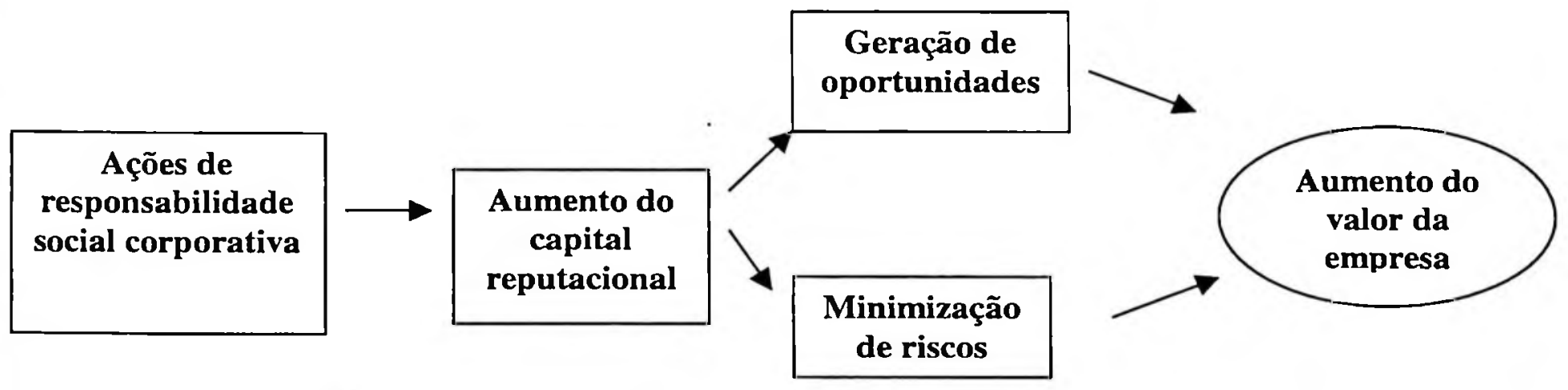

Fonte: Adaptado de Fombrun, 2000 .

A lógica apresentada no modelo é de que as empresas com atividades de responsabilidade social podem obter ganhos de capital reputacional, alavancando oportunidades de negócios, reduzindo riscos potenciais de sua conduta no mercado, preservando ou gerando aumento do valor da empresa.

Entretanto, Fombrun salienta que não se pode estabelecer uma correlação direta entre o desempenho social corporativo (Corporate Social Performance CSP) e o desempenho financeiro corporativo (Corporate Financial Performance CFP), argumentando que as atividades que geram 0 desempenho social 
corporativo não afetam diretamente a performance financeira, mas afetam o estoque de capital reputacional e, conseqüentemente, o valor financeiro dos ativos intangiveis da organização.

Chauvin e Hirschey (1994) sustentam que a ação filantrópica tem um efeito positivo no valor de mercado das firmas. Os investidores são mais propensos a confiar seus recursos a empresas que desfrutam de uma reputação superior, em função dos menores riscos percebidos e das oportunidades potenciais de marketing criadas. As empresas estão respondendo à insistência dos consumidores em lidar somente com empresas que ostentam uma boa imagem, e a filantropia corporativa é um dos meios de criar tal imagem .

"...giving to charity increases demand or decreases demand elasticity for a firm's product". (NAVARRO apud JONES e RUBIN, 1999) ${ }^{36}$.

A ação da mídia e e os riscos de ações judiciais têm levado as organizações a adotarem códigos de conduta, a fim de evitar eventuais perdas de valor reputacional, causadas por escândalos ou ações judiciais. Williams e Barret (2000) estudaram a relação entre empresas que praticavam atos filantrópicos e a restauração de imagem, abalada por eventuais atos ilegais praticados. De acordo com os resultados do estudo, as ações filantrópicas serviram para restaurar parcialmente a abalada imagem das empresas que praticaram atos ilegais.

As ações filantrópicas estão inseridas na visão da teoria dos stakeholders, de que as empresas possuem responsabilidades sociais para com um amplo conjunto de agentes, entre os quais as comunidades que podem se beneficar de

${ }^{36}$ NAVARRO, Peter. Why do Corporations Give to Charity? JONES, Kari ; RUBIN, Paul H. Effects of Harmful Environmental Events on Reputation Firms. working paper, Social Science Research Network Eletronic Library, abr., 1999. Disponível em: < http://papers.ssrn.com.taf?abstract id158849>. Acesso em: 03 set.1999. 
ações de filantropia corporativa. O tópico a seguir apresentará os principais argumentos utilizados pelos defensores e críticos da teoria dos stakeholders.

\section{3- O DEBATE DA TEORIA DOS STAKEHOLDERS}

\subsection{1 - A Teoria dos Stakeholders e as ações de responsabilidade social corporativa}

O primeiro autor a discutir explicitamente a teoria dos stakeholders, segundo Marens e Wicks (2000) foi Eduard Freeman (1984), em artigo clássico intitulado "The Politics of Stakeholder Theory: Some Future Directions"37. A gestão com base na teoria dos stakeholders envolve a alocação de recursos organizacionais e a consideração dos impactos desta alocação em vários grupos de interesse dentro e fora da organização. $O$ autor propõe a divisão dos stakeholders em 2 grupos (primários e secundários), de acordo com os direitos estabelecidos nos recursos organizacionais.

Os stakeholders primários (acionistas e credores) são aqueles que possuem bem estabelecidos os direitos legais sobre os recursos organizacionais. Os stakeholders secundácios (comunidade, funcionários, consumidores, entre outros) são aqueles cujo direito sobre os recursos organizacionais é menos estabelecido em lei e/ou é baseado em critérios de lealdade ou em obrigações éticas. A doutrina da teoria dos stakeholders baseia-se na idéia de que o resultado final da atividade de uma dada organização empresarial deve levar em consideração os retornos que otimizam os resultados de todos os stakeholders envolvidos, e não apenas os resultados dos acionistas. As ações de responsabilidade social com base na teoria dos stakeholders se justificariam, conforme salientado por Wood (1991, p. 695 apud JONES, M., 1999) ${ }^{38}$ :

\footnotetext{
${ }^{37}$ FREEMAN, Edward R. The Politics of Stakeholder Theory: Some Future Directions. Business Ethics Quarterly, v.4 p. 409-422, 1994.

${ }_{38}$ WOOD, D. Corporate Social Performance Revisited. In: JONES, Marc T. The Institutional Determinants of Social Responsibility. Journal of Business Ethics. Netherlands: Kluwer Academic Publishers. v. 20, p. 163-179, 1999.
} 
A idéia básica da responsabilidade social corporativa é que a atividade de negócios e a sociedade são entidades interligadas e não distintas. Portanto, a sociedade tem certas expectativas em relação ao comportamento e resultados das atividades de negócios.

A figura 6 apresenta o modelo de stakeholder das organizações, conforme Freeman (2000).

Figura 6 - O Modelo da teoria dos Stakeholders

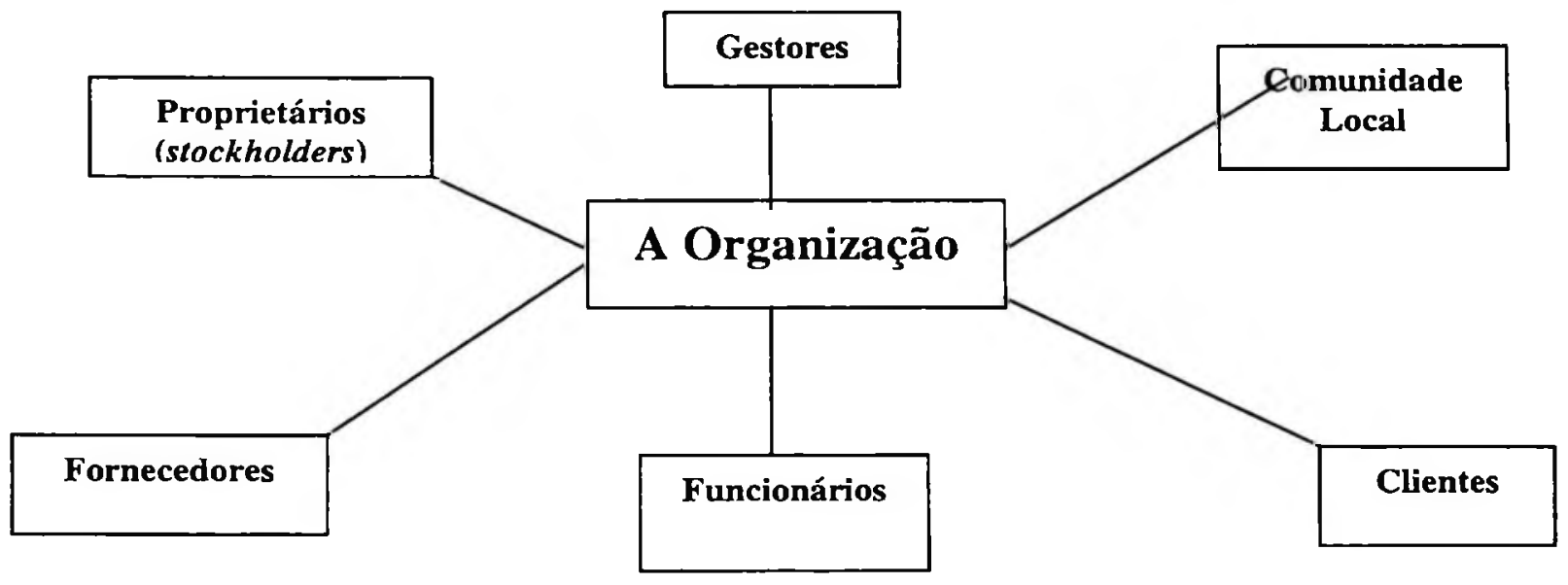

Fonte: Freeman, 2000.

Segundo este modelo, os proprietários têm uma porção (stake) financeira da organização, na forma de ações ou cotas, e esperam algum tipo de retorno por esta porção. O tipo de proprietário, neste caso, pode variar amplamente, desde o de uma empresa familiar, onde pode ser o próprio gestor e funcionário, até o acionista de uma grande corporação com milhares de acionistas, todos eles tendo uma determinada porção do capital da organização. 
Os funcionários têm os seus empregos e em grande medida sua vida pessoal dependente da organização. Em troca de seu trabalho esperam da organização salários, segurança, benefícios, entre outros.

Os fornecedores, considerados como stakeholders, são vitais para o sucesso da organização, pois o suprimento de matérias-primas irá determinar a qualidade e o preço final dos produtos. Por outro lado, a organização é cliente de seu fornecedor, e também um stakeholder deste.

Os consumidores trocam recursos com a organização, recebendo seus produtos e/ou serviços e fornecendo o recurso monetário vital para a sobrevivência da organização.

A comunidade local garante à organização o direito de construir suas facilidades, plantas industriais, escritórios, recebendo em troca os benefícios de taxas e contribuições da organização. Além disto, a organização deve cuidar para atenuar ou não gerar as externalidades negativas causadas à comunidade local, como por exemplo em aspectos ambientais, como a poluição do ar e da água.

Freeman vai além de destacar a importância de os gestores (agentes) atuarem no sentido de maximizar o valor para todos os seus stakeholders (principais), e propõe um modelo normativo em que os gestores teriam obrigações fiduciárias, não apenas para com os stockholders, mas também para com os demais stakeholders.

Esta posição de Freeman é contestada por Marens e Wicks (2000), que vêem exagero nesta posição:

As firmas têm autonomia legal para agir proativamente e avançar buscando os interesses de um conjunto de stakeholders simultaneamente. A teoria dos stakeholders não deve ser encarada como uma antítese ou resposta à "teoria dos shareholders" de Friedman, mas como uma teoria 
mais atrativa, inclusiva e realista de como as organizações empresariais podem e deveriam operar.

Freeman não inclui os competidores e o governo em seu modelo, entretanto destaca que muitas vezes os interesses de competidores em uma determinada indústria não são conflitantes, e enfatiza o papel das associações e organizações de classe na busca de interesses comuns.

Fombrun (2000) amplia o conjunto de stakehoders relacionados por Freeman, para a análise das possiveis conseqüências relativas às oportunidades e minimização de riscos que as ações de responsabilidade social podem gerar de acordo com o stakeholder envolvido.

A tabela 3 apresenta um quadro-resumo das oportunidades de ganhos ou minimização de riscos de acordo com o "stakeholder" envolvido, a partir de ações de responsabilidade social. 
Tabela 3 - Efeitos das ações de responsabilidade social de acordo com o stakeholder envolvido

\begin{tabular}{|c|c|c|}
\hline Stakeholder envolvido & $\begin{array}{l}\text { OPORTUNIDADES } \\
\text { (Ganhos de } \\
\text { reputaçāo) }\end{array}$ & $\begin{array}{l}\text { MINIMIZAÇĀO DE } \\
\text { RISCOS }\end{array}$ \\
\hline Comunidade & Criação de legitimidade & $\begin{array}{l}\text { Minimizar risco de má } \\
\text { aceitação/conflitos }\end{array}$ \\
\hline Mídia & Cobertura favorável & $\begin{array}{ccc}\text { Minimizar risco } & \text { de } \\
\text { cobertura desfavorável }\end{array}$ \\
\hline Ativistas & - & $\begin{array}{lll}\text { Minimizar risco } & \text { de } \\
\text { boicote } & & \\
\end{array}$ \\
\hline Investidores & Geraçāo de valor & $\begin{array}{l}\text { Minimizar risco de fuga } \\
\text { de investidores }\end{array}$ \\
\hline Funcionários & $\begin{array}{cc}\text { Aumento } & \text { do } \\
\text { Comprometimento } & \end{array}$ & $\begin{array}{l}\text { Minimizar risco } \mathrm{de} \\
\text { comportamento }\end{array}$ \\
\hline Consumidores & Fidelização & $\begin{array}{l}\text { Minimizar risco de má } \\
\text { aceitação/ } \\
\text { Desentendimentos }\end{array}$ \\
\hline Agentes reguladores & Ação legal favorável & $\begin{array}{l}\text { Minimizar risco de ação } \\
\text { legal }\end{array}$ \\
\hline Parceiros comerciais & Colaboraçāo & $\begin{array}{lll}\text { Minimizar } & \text { risco } & \text { de } \\
\text { defecçāo } & & \end{array}$ \\
\hline
\end{tabular}

Fonte: Adaptado de Fombrun (2000).

Segundo Borger, (2001):

A atuação das empresas orientada para a responsabilidade social não implica que a gestão empresarial abandone os seus objetivos econômicos e deixe de atender os interesses de seus proprietários e acionistas, pelo contrário, uma empresa é socialmente responsável se desempenha seu papel econômico na sociedade produzindo bens e serviços, gerando empregos, retorno para os seus acionistas dentro das normas legais e éticas da sociedade. Mas cumprir o seu papel econômico 
nāo é suficiente, a gestão das empresas é responsável pelos efeitos de sua operação e atividades na sociedade.

\subsection{2 - A visão crítica à Teoria dos Stakeholders}

Jensen (2000) se contrapõe à "teoria dos stakeholders" que em essência proclama que a empresa deve assumir múltiplos objetivos e não apenas a funçãoobjetivo de maximização da riqueza do acionista. A argumentação central da teoria dos stakeholders é de que os administradores devem também tomar decisões levando em conta os interesses de todos os grupos envolvidos (stakeholders primários e secundários).

Jensen aponta sérios erros conceituais nesta ótica. $O$ autor reitera, na mesma linha dos argumentos apresentados por Friedman, a lógica de a empresa seguir apenas uma função-objetivo, qual seja, a busca da maximização do valor de mercado da empresa (value seeking). Segundo Sternberg (1999), a teoria dos stakeholders vem sendo apresentada como um modelo "corretivo" dos erros percebidos na governança corporativa e da ética nos negócios, e vem sendo disseminada de forma tão ampla que acaba se tornando a "nova ortodoxia".

Entretanto, a autora também levanta severas críticas a esta teoria. A primeira delas está na "obviedade" de alguns pressupostos da teoria, como o fato de que as pessoas têm mais interesse de se envolver em um dado processo quando participam, de alguma forma, seja nos resultados ou no processo de tomada de decisão. A outra pressuposição "simplista", segundo a autora é a da própria "complexidade" do mundo dos negócios tomada como um novo paradigma pelo teoria dos stakeholders. Neste sentido, segundo a autora, a teoria dos stakeholders não estaria, de fato, trazendo nada de novo a ser agregado à teoria tradicional: "esta é uma verdade básica, que as atividades de negócios bem sucedidas há muito tempo entenderam e respeitam" (STERNBERG,1999). 
Jensen (op.cit.) sustenta que os múltiplos objetivos da "teoria dos stakeholders" são, na verdade, estratégias, e a criação de valor o principal objetivo a ser seguido como referência. Na mesma linha apontada por Jensen, Sternberg (op.cit.) chama a atenção para um desvio implícito na teoria dos stakeholders, que acaba "mascarando" a possibilidade de avaliação da performance da gestão: os gestores podem se "amparar" nos múltiplos objetivos difusos da organização para justificar decisões tomadas que não necessariamente estejam na direção da busca de maximização de valor dos acionistas (stockholders), causando um sério desvio na relação "agente-principal".

Vale destacar que tanto a argumentação de Jensen como de Sternberg não são a priori contrárias à prática de ações de responsabilidade social por parte das empresas. Tais práticas, numa visão pragmática, podem servir estrategicamente no processo de busca de valor (value seeking) por parte das organizações. Uma vez que a firma não pode ignorar o interesse dos stakeholders para atingir os objetivos de maximização, alguns trade-offs podem ser aceitos, realocando recursos no curto prazo para suprir os interesses dos stakeholders.

Na visão de Jensen, estes são aspectos de estratégia e tática empresarial, que não perdem de vista a função-objetivo única de criação de valor para a empresa.

O tópico a seguir irá explorar o conceito de governança corporativa e suas relações com a teoria dos stakeholders, abordando em especial a eficiência de diferentes formas organizacionais para lidar com açōes de responsabilidade social. 


\section{4 - ESTRUTURA ORGANIZACIONAL PARA LIDAR COM ATIVIDADES DE RESPONSABILIDADE SOCIAL}

\subsection{1 - Governança corporativa e a Teoria dos Stakeholders}

O conceito de Governança Corporativa vem sendo progressivamente difundido no ambiente empresarial. Baseia-se nos princípios de transparência, eqüidade, prestação de contas (accountability) e ética. O Instituto Brasileiro de Governança Corporativa (2001) define da seguinte forma o conceito: "São as práticas e os relacionamentos entre os acionistas/cotistas, conselho de administração, diretoria, auditoria independente e conselho fiscal, com a finalidade de otimizar o desempenho da empresa e facilitar o acesso ao capital".

$\rightarrow$ Na visão de Koehn (2001), governança corporativa é a arte de governar empresas de forma que se busque os interesses de longo prazo da empresa e de seus stakeholders. Tendo em vista que as firmas não podem existir sem o suporte destes stakeholders, as empresas bem governadas consistentemente atuam no sentido de atender às demandas de seus empregados, clientes, acionistas e comunidade em geral.

É curioso notar que embora os conceitos que embasam a teoria dos stakeholders sejam em grande medida convergentes para o conceito de governança corporativa, no sentido de ampliar a voz e a transparência da informação entre os diversos grupos de interesse nas atividades da organização, tal associação não é simples, e muitas vezes podem ocorrer situações contraditórias.

Pode-se supor a situação de uma grande corporação, com milhares de proprietários acionistas. Tais acionistas (stockholders) podem ter expectativas e interesses distintos conforme a sua porção (stake) na organização. Por exemplo, os gestores da empresa podem propor uma determinada ação na comunidade, ou 
uma política de alocação sistemática de recursos para causas sociais, que não teriam consenso entre os proprietários. Muitos poderiam ser contra, seja por não terem informação simétrica de possiveis retornos positivos destas açōes, ou por não compartilharem a mesma visão filosófica sobre a função social das organizações na sociedade. Nestas situações, muitos proprietários podem encarar estas atividades como desvio de recursos e potencial diminuição de seus retornos esperados.

Koehn (op.cit.) nota que os acionistas, na prática, constituem a categoria mais vulnerável entre os stakeholders, num mercado livre e aberto. Os clientes que se sentem atingidos pela empresa podem deixar de adquirir seus produtos ou serviços. Muitas das categorias de funcionários são protegidas por sindicatos. Mas o acionista que investe na empresa depende exclusivamente dos gestores para proteger e incrementar o valor de suas ações. Neste sentido, as práticas de governança corporativa constituem uma forma de proteção aos acionistas, especialmente aos minoritários, ante os gestores que conduzem a organização.

Algumas práticas de governança corporativa são citadas por Koehn (op. cit.), p.7:

- Facilitar o processo de voto a todos os acionistas;

- Direta e regularmente estabelecer a comunicação entre a direção da empresa e os acionistas;

- Propiciar adequada informação sobre assembléias para que os acionistas possam participar;

- Possuir uma auditoria independente e forte;

- Apresentar informações financeiras de forma transparente, facilitando comparaçōes entre o desempenho das empresas do setor. 
A forma como as atividades de responsabilidade social são estruturadas na empresa tem implicações para a governança corporativa, daí a necessidade de transparência e monitoramento no processo de implementação das ações.

Com base na argumentação apresentada por alguns autores enfatizando os potenciais problemas de agência embutidos na teoria dos stakeholders (JENSEN, 2000; STERNBERG, 1999; FRIEDMAN, 1970; ZYLBERSZTAJN, 2000), a discussão sobre a estrutura organizacional para a condução de ações de responsabilidade social ganha importância.

Assumindo que, em certas situaçōes, as açōes de responsabilidade social podem estar alinhadas com a função-objetivo da empresa de maximização de valor (visão socioeconômica ou moderna, segundo a classificação de Quazi e O'Brien (2000), uma outra discussão importante se refere à comparação de estruturas organizacionais alternativas para a condução de ações sociais, interna ou externamente aos limites da firma.

Ou seja, a opção interna é aquela de acordo com a qual a empresa opera as ações de responsabilidade social dentro da sua própria estrutura organizacional, mantendo estas atividades no seu organograma. A opção externa é aquela consoante a qual a empresa desenvolve parcerias com outras instituições, aportando recursos mas não operando diretamente as ações de responsabilidade social, ou mesmo criando uma organização própria para operar as ações sociais, como uma fundação sem fins lucrativos.

A Figura 7 destaca três tipos de estrutura para a empresa lidar com ações de responsabilidade social. 
Figura 7 - Três estruturas alternativas para desenvolver ações de responsabilidade social.

Opção A - A empresa internaliza as atividades, operacionalizando diretamente os

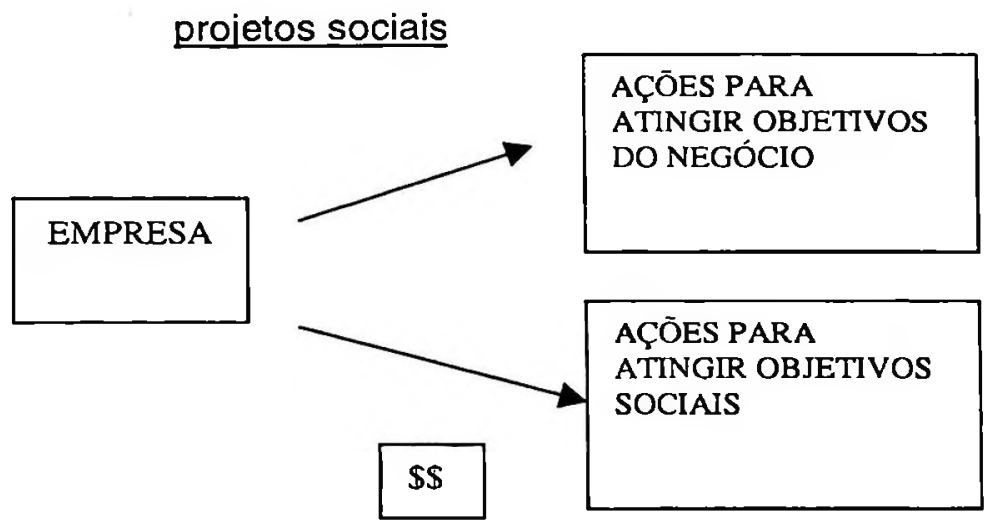

$\underline{O p c ̧ a ̃ o} B-\underline{A}$ empresa desenvolve ações sociais por meio de outra organização

$\underline{\text { sob seu controle }}$

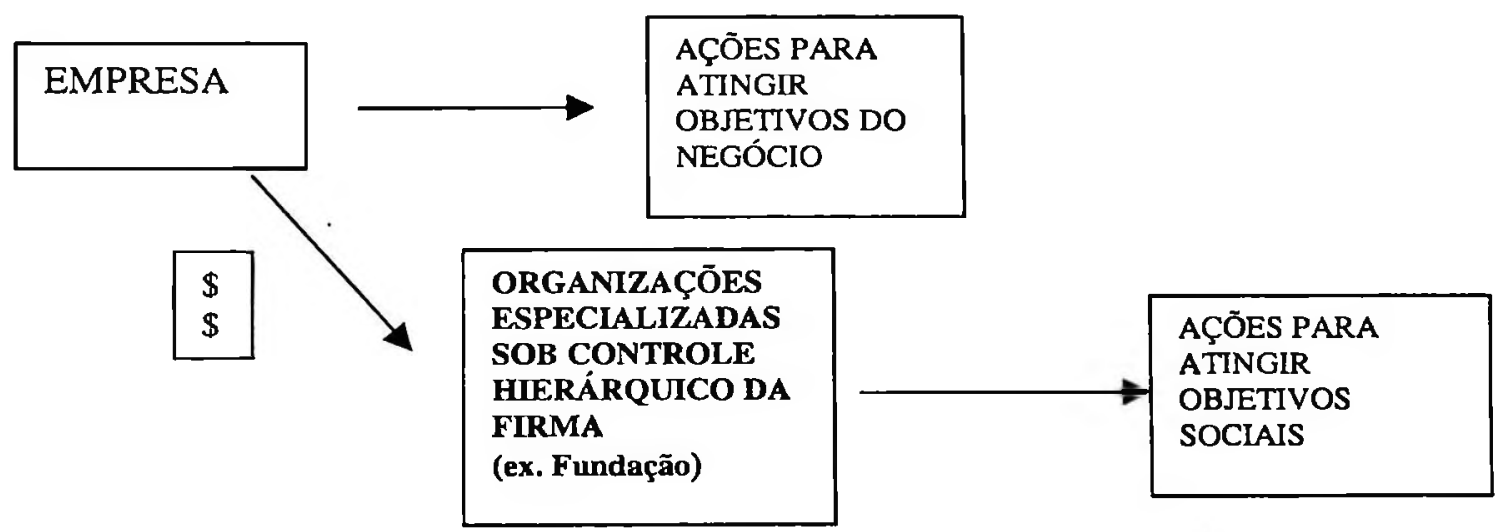

Opção $C$ - A empresa desenvolve ações sociais por meio de parcerias com outras organizações, sem operacionalizar diretamente as atividades

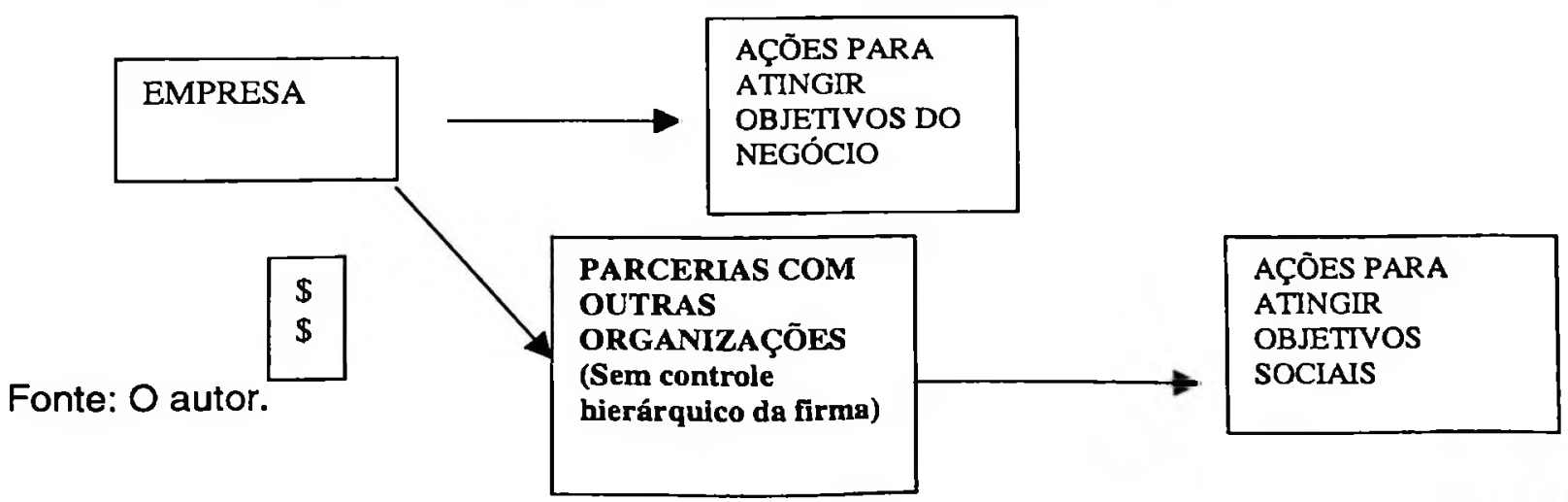


Para analisar esta questão, dois referênciais teóricos serão utilizados: a Economia dos Custos de Transação (ECT) e a teoria da Agência.

\section{a) O Enfoque da ECT - Grau de verticalização da atividade}

De acordo com Williamson (1985), as principais dimensões a serem observadas na descrição das transações são a especificidade dos ativos, incerteza e a freqüência. Os ativos são classificados pelo autor em três classes: não-específicos, mistos ou altamente específicos; quanto à freqüência, as transações são classificadas em recorrentes, ocasionais ou únicas.

Quanto maior a freqüência das transações, maiores as vantagens em manter estruturas especializadas, com menores custos fixos médios. Por exemplo, a aquisição de um equipamento a ser utilizado em uma linha de produção não ocorre com freqüência e a transação é única. No entanto, a aquisição de um determinado insumo industrial que será utilizado continuamente é uma transação do tipo recorrente.

A incerteza é sobre a qual, dos três atributos das transações considerados por Williamson, tem-se um menor desenvolvimento conceitual. Basicamente, pode-se considerar que existam dois tipos de incerteza: a incerteza proveniente do comportamento estratégico dos agentes, isto é, a incerteza decorrente da impossibilidade de saber quais ações os agentes irão colocar em prática; e a incerteza de contingência (estado da natureza), ou seja, a incerteza inerente à própria atividade relativa à impossibilidade de prever todas as possibilidades ou contingências que ocorrerão num tempo futuro e afetarão a atividade.

A especificidade dos ativos se refere a quanto um determinado ativo é específico à atividade, e quão custosa é a sua realocação. Williamson (1985) 
define basicamente seis tipos de especificidade dos ativos: locacional (ex: grau de proximidade física), temporal (ex: perecibilidade), humana (ex: funcionários altamente qualificados), física (ex: componentes específicos de um produto), ativos dedicados (investimentos do tipo sunk costs ${ }^{39}$ ) e de marca (brand name).

À medida em que a especificidade aumenta, aumentam também as implicações decorrentes de comportamentos oportunistas dos agentes, pois surgem quase-rendas associadas. $O$ conceito de quase-rendas é tratado como o excesso de valor de um ativo sobre o seu uso de oportunidade ou valor residual. Assim, conforme a especificidade se eleva, quase-rendas são criadas, aumentando as possibilidades para ações oportunísticas (Williamson, 1985).

A partir da análise destes atributos envolvidos nas transações, o autor identifica as formas de "governança" mais eficientes em reduzir os custos de transações. Segundo Williamson (1985), a existência de uma variedade de arranjos contratuais, sob a ótica da ECT, advém das diferenças de atributos das transações reguladas por estes contratos.

As três opções alternativas ilustradas na figura 8 podem ser analisadas sob a ótica da ECT, especialmente quanto à especificidade da marca e à especificidade locacional.

Opção A - Internalização da atividade social, por meio da operacionalização direta de projetos sociais pela própria estrutura organizacional da empresa.

É o caso em que existiria alta especificidade das ações da empresa, em função do tipo e do local das ações sociais a serem desenvolvidas, por exemplo: ações sociais/ambientais que têm efeito direto e interligado com a atividade central

\footnotetext{
${ }^{39}$ Ativos irrecuperáveis.
} 
da empresa, como uma determinada ação corretiva ou preventiva de potenciais efeitos ambientais da empresa na sua área de atuação.

Também é o caso de uma ação social intrinsecamente relacionada com a atividade e a performance empresarial, especialmente as ações internas dirigidas aos próprios funcionários. Ou o caso de quando se deseja explorar de forma intensa a especificidade da marca, associando diretamente determinada prática de responsabilidade social ao negócio da empresa.

Opção B - Criação de uma estrutura própria especializada em atividades sociais.

É o caso de uma organização especializada (ex: Fundação), criada especificamente para lidar com as ações de responsabilidade social dirigidas à comunidade, sob controle da empresa mantenedora.

Este caso justifica-se sob a ótica da ECT quando não existe necessariamente uma ligação intrínseca direta entre a ação de responsabilidade social e a atividade central da empresa. Entretanto, a empresa controladora deseja manter sob seu controle os objetivos básicos e as estratégias desta organização, e, de alguma forma, explorar a "especificidade da marca", associando a imagem da empresa às atividades sociais desenvolvidas pela organização sob seu controle hierárquico.

Opção C - Ações sociais por meio de parcerias com outras organizações.

Nesta opção, a empresa não opera diretamente as ações sociais, e também não mantém sob seu controle uma organização externa para lidar com ações sociais. As iniciativas da empresa neste caso são "spot" , ou seja, dão-se por meio de doações, contratos de parceria ou outras formas indiretas de atuação social.O grau de envolvimento e o comprometimento com os resultados e conseqüências das ações sociais são menores que nos modelos anteriores. 
b) - O Enfoque da Teoria da Agência - Alinhamento dos interesses do principal (acionista) e do agente (gestor)

De acordo com o enfoque da Teoria de Agência, deve-se considerar que a estrutura seja capaz de atingir dois requisitos:

1 - A minimização dos custos de agência (conflitos na relação agente principal);

2 - A efetividade das ações sociais.

A hipótese baseada na discussão teórica apresentada no capítulo anterior é de que a estrutura fora da firma (Opção B) cumpriria melhor os requisitos citados, a partir de uma certa escala das ações sociais. Primeiramente, porque haveria uma clara separação das funções-objetivo das duas organizações. A empresa poderia financiar a organização externa (sob seu controle hierárquico) com uma quantidade especificada de recursos, e os agentes seriam responsáveis pelas ações, monitorados pelos donatários (em última instância, os acionistas da empresa). Os agentes da empresa, por sua vez, estariam concentrados somente nas estratégias e ações voltadas para os objetivos do negócio.

A outra razão é baseada no argumento funcional, pois os tipos de ação e o perfil dos agentes que lidam com organizações com e sem fins lucrativos são diferentes em muitos aspectos. Como conseqüência, o grau de especialização requerido para o gerenciamento destas organizações é distinto. As ações tanto dos agentes da empresa com fins lucrativos como doas agentes da empresa social se tornam mais transparentes e verificáveis. Em tese, estes argumentos sustentam a separação de funções (objetivos do negócio e objetivos sociais) entre diferentes entidades. Mas a separação das atividades requer um claro e eficaz sistema de monitoramento e controle. 
O tópico a seguir destaca a emergência do chamado "terceiro setor" na atividade econômica. As fundações empresariais (exemplo de opção B no modelo citado) se enquadram neste universo.

\subsection{2 - O Terceiro Setor e sua Relação com o Ambiente Empresarial}

Algumas evidências recentes demonstram a crescente importância dada pelo empresariado nacional à evolução do chamado "Terceiro Setor". Segundo relatório do BNDES (2000), este setor é definido como:

O conjunto das atividades privadas com fins públicos e sem fins lucrativos, composto por instituições civis de qualquer origem - religiosa, comunitária, de trabalhadores, institutos e fundações empresariais, organizaçōes não governamentais e outras - deferenciando-se da lógica estrita de governo (público com fins públicos) e de mercado (privado com fins privados).

Segundo Cardoso (2000), foi o americano John D. Rockefeller quem cunhou a expressão Terceiro Setor, publicando em 1975 o primeiro estudo detalhado sobre a importância das iniciativas empresariais com sentido público na sociedade americana. ${ }^{40}$

\footnotetext{
${ }^{40} \mathrm{O}$ estudo intitulou-se "The Third Sector $X " 1,1975$, tendo sido o principal inspirador da Comission on Private Philanthropy and Public Needs, USA. Segundo Rockefeller apud Cardoso (2000): "Refiro-me a um setor menos visivel do que o normalmente dominante no mundo dos negócios a do governo. Enquanto estes dois reinos foram e continuam a ser microscopicamente examinados e analisados, e suas fronteiras em geral já foram identificadas por especialistas e leigos de plantāo, o terceiro setor - constituldo por organizaçōes e associaçōes nāo governamentais e sem fins lucrativos - continua a ser como uma terra incógnita, quase inexplorada no que diz respeito a sua dinâmica intema, suas motivaçōes e suas relaçōes sociais, econômicas e políticas com o resto do mundo. (...) Na verdade, é no seio desta esfera institucional que quase toda a contribuiçāo filantrópica - doaçōes e voluntariado - se transforma em ação de ajuda, ou seja, bens e serviços para os beneficiários finais".
} 
No Brasil, destacam-se três organizações de terceiro setor com papel catalizador importante na disseminação da cidadania empresarial: $O$ Grupo de Institutos, Fundações e Empresas (GIFE), o Instituto Ethos e a Fundação Instituto de Desenvolvimento Social e Empresarial (FIDES) e o Instituto Brasileiro de Análises Sociais e Econômicas (IBASE). O GIFE procura orientar empresas e fundações na realização de projetos sociais e o Instituto Ethos apóia as empresas na implementação de medidas socialmente responsáveis. Ambas são inspiradas na organização americana Business for Social Responsibility (BSR).

O Instituto Ethos, o FIDES e o IBASE orientam as empresas na elaboração do Balanço Social, publicação empresarial com informaçōes e indicadores de investimento e ações realizadas pelas empresas no cumprimento de sua função social junto aos funcionários, governo e às comunidades com as quais interagem.

A despeito da emergência das fundações empresariais, Cardoso (2000) afirma que, no Brasil, a maioria das empresas com programas sociais não possuem estrutura especializada para o gerenciamento dos investimentos sociais. Esta estrutura contribuiria para uma maior qualidade e eficiência na aplicação de recursos. No contexto brasileiro, segundo pesquisa realizada pelo CEATS em $2001^{41}$, foi feita uma caracterização da atuação social de um conjunto de empresas e o mapeamento das formas de atuação delas. Das empresas consultadas, de uma amostra de $\mathbf{3 7 9}$ questionários enviados para empresas com atuação social, $78 \%$ desenvolviam ações sociais sem fundações próprias de apoio e $22 \%$ desenvolviam ações por meio de fundações.

Cardoso (op.cit., p.119), ressalta que:

Ainda são as áreas de relações institucionais, publicidade $e$ marketing ou comunicação que tomam as decisōes sobre que projetos

\footnotetext{
${ }^{41}$ Relatório preliminar de pesquisa do Centro de Estudo em Administração do terceiro Setor (CEATS): Alianças Estratégicas Intersetoriais para Atuaçāo Social', apresentado à Faculdade de Economia, Administração e Contabilidade da USP. São Paulo, 13 dez. 2001.
} 
apoiar. São poucas as empresas que acompanham de perto e avaliam o que acontece com as açōes sociais por elas apoiadas ou realizadas. Esta relativa deficiência de pessoal qualificado para coordenar as açōes sociais também dificulta a produção de um conhecimento de qualidade sobre os resultados dos projetos, bem como o intercâmbio de experiências e a geração de sinergias entre iniciativas similares.

O tópico a seguir destaca as evidências empíricas do impacto para as organizações das ações de responsabilidade social, a partir de estudos e fatos recentes. 


\section{5 - A IMPORTÂNCIA DAS AÇÕES SOCIAIS - EVIDÊNCIAS EMPÍRICAS NO CONTEXTO EMPRESARIAL}

Ao mesmo tempo em que se aprofunda o debate na comunidade acadêmica sobre as diferentes teorias que embasam a questão da responsabilidade social e da ética, cresce também na comunidade de negócios o questionamento sobre a real conexão entre as práticas de responsabilidade social e a performance econômica e financeira das empresas. Este tipo de correlação vem sendo analisado em vários estudos acadêmicos recentes, embora com resultados muitas vezes contraditórios e inconclusivos (JONES e MURRELL, 2001).

No ambiente empresarial, a percepção de que $\circ$ exercício da responsabilidade social pode trazer retornos à empresa é crescente, embora com pouca comprovação empírica. O Banco Nacional de Desenvolvimento Econômico e Social divulgou um relatório relacionando empresas e responsabilidade social, assinalando a possível existência de ganhos de reputação positiva (BNDES, 2001):

$\mathrm{Na}$ visão de governança corporativa exclusivamente direcionada para a performance financeira, o exercício da responsabilidade social pode ser entendido, à primeira vista, como um custo adicional para as empresas, seus sócios e acionistas, pois são recursos que de outra maneira estariam sendo reinvestidos ou distribuídos na forma de lucros e dividendos. Todavia, a adoção de uma postura pró-responsabilidade social parece indicar que há ganhos tangiveis para as empresas, sob a forma de fatores que agregam valor, reduzem custos e trazem aumento de competitividade, tais como a melhoria da imagem institucional, criação de um ambiente interno e externo favorável, estímulos adicionais para melhoria e inovações nos processos de produção, incremento na demanda por produtos, 
serviços e marcas, ganho de participação de mercados e diminuição de instabilidade institucional e política locais, entre outros. ${ }^{42}$

Jones e Murrell (2001) sustentam que a relação entre ações de responsabilidade social e performance financeira é em essência inconclusiva, pois ,dependendo do contexto, evidentemente existirão correlações positivas e negativas entre $o$ investimento em ações de responsabilidade social e a performance financeira.

Adicionalmente, o desafio da demonstração desta relação é explicável, pois alguns tipos de ações de responsabilidade social, como o envolvimento comunitário (filantropia), as ações ambientais, entre outras, não têm ligações diretas facilmente mensuráveis com a operação dos negócios. $\mathrm{Na}$ visão dos autores, mais do que buscar respostas conclusivas a esta temática, deve-se considerar, de fato, a instrumentalização dos administradores para a tomada de decisão sobre o tipo e o grau de investimentos em atividades de responsabilidade social que possam trazer maiores retornos à empresa.

A seguir, será apresentada de forma sistematizada uma revisão dos principais estudos que destacam as potenciais conseqüências das ações de responsabilidade social corporativa. Embora não se possa tirar conclusões robustas dos estudos do ponto de vista da causalidade, os resultados constituem, de forma agregada, evidências importantes dos efeitos das ações de responsabilidade social nas empresas.

\footnotetext{
${ }^{42}$ Empresas, Responsabilidade Corporativa e Investimento Social - Uma abordagem Introdutoria: Relatónio Setorial 1 AS/GESET, p. 6 - BNDES, março de 2000.
} 


\subsection{1 - Melhoria da Performance Econômica e Acesso ao capital dos Investidores}

Em 1999, estudo apresentado na Business and Society Review (BSR, 2000) constatou evidências a partir de amostra das 300 maiores corporações americanas: as companhias que assumiram o comprometimento público de seguir um código de conduta ética superaram 2 ou 3 vezes em performance as empresas do setor no que se refere ao valor de mercado adicionado.

Segundo Oliveira Neto, (2000), uma pesquisa realizada em 1999 pela Universidade de Defoe/EUA, analisando o faturamento das 1000 maiores empresas norte-americanas, mostra que num período de 10 anos as empresas que investiram na formação de consciência ética tiveram um aumento de 4,5 vezes no seu faturamento, em comparação às empresas que não implementaram este tipo de ação ${ }^{43}$.

Um estudo realizado pela Southwestern Louisiana - The Effect of Published Reports on Ethical Conduct on Stock Prices - (BSR, 2000) mostrou que a publicidade adversa de comportamentos não éticos de empresas teve impacto negativo no preço das ações em um período mínimo de 6 meses.

Outra evidência, destacada por Safatle (2000), fundamenta-se na comparação entre os índices Dow Jones Global, da Bolsa de Nova York, e Dow Jones Sustainability Group Index, formado por ações de empresas classificadas como socialmente responsáveis. Tomando-se como base o período de 1994 a

\footnotetext{
43 Estes estudos devem ser considerados com muita cautela, pela dificuldade metodológica na qualificação das ações de responsabilidade social empreendidas, e também porque é diffcil estabelecer uma relaçāo de causa e efeito. Pode-se partir da premissa de que as empresas em condições de empreender atividades sociais são justamente aquelas que apresentam indicadores de performance e crescimento mais robustos. Neste sentido, ficaria diffcil distinguir a variável dependente da independente num estudo de relação causal.
} 
2000, a partir de uma base $100 \mathrm{em}$ 1994, o indice Dow Jones Global atinge o patamar de 248 contra cerca de 300 do índice Dow Jones Sustainability.

O indice Dow Jones Sustainability foi criado pela Dow Jones \& Companye pelo Sustainability Asset Management Group (SAM), da Suiça; representa atualmente 9 setores e 73 segmentos industriais de 33 países. Os critérios para o enquadramento das empresas levam em conta aspectos ecológicos, sociais e econômicos, com equilíbrio entre estes.

A preocupação dos investidores com o aspecto da responsabilidade social e da conduta ética das empresas é outra evidência apontada em alguns estudos. De acordo com dados publicados nos relatórios do Social Investment Forum ${ }^{44}$, o total de ativos investidos em carteiras administradas que utilizaram pelo menos uma forma de investimento social passou de US\$ 59 milhões em 1984 para US\$ 2,16 trilhões em 1999, representando cerca de $13 \%$ do total de ativos. Os recursos destinados a programas de investimentos comunitários nos EUA cresceram de US\$ 4 bilhões em 1997 para US\$5,4 bilhões em 1999 (BNDES, 2000).

No Brasil, algumas evidências de que o critério de responsabilidade social passa a ser importante para os investidores começam a surgir. A Associação Brasileira dos Analistas de Mercado de Capitais (ABAMEC) ${ }^{45}$ realizou uma pesquisa em agosto de 2001, visando a diagnosticar a percepção dos agentes do mercado sobre as informações de natureza social utilizadas para a análise das empresas. $^{46}$ A tabela 4 relaciona algumas perguntas dos questionários e respostas dos entrevistados.

\footnotetext{
${ }^{44}$ Associação norte- americana que tem como objetivo a promoção do conceito e da prática do investimento social responsável.

${ }^{45}$ A ABAMEC é uma organização fundada em 1970, que congrega pessoas físicas que exerçam função de analista do mercado de capitais; contava em 2001 com cerca de 3000 profissionais associados.

${ }^{46} \mathrm{Em}$ apresentação realizada durante o Seminário Internacional sobre Investimentos Socialmente Responsáveis, realizado nos dias 29 e 30 de dezembro de 2001 em São Paulo.
} 
Tabela 4 - Relevância de itens de responsabilidade social na análise da companhia - visão dos analistas de mercado

\begin{tabular}{l|c|c}
\hline Pergunta & $\begin{array}{c}\text { Resposta } \\
\text { SIM }\end{array}$ & $\begin{array}{c}\text { Resposta } \\
\text { NĀO }\end{array}$ \\
\hline A ação social interna é relevante na análise da companhia? & $85 \%$ & $15 \%$ \\
\hline A açāo social externa é relevante na análise da companhia? & $66 \%$ & $34 \%$ \\
\hline E importante fazer projeções das informaçōes numéricas do Balanço & $79 \%$ & $21 \%$ \\
Social (BS) ? & & $21 \%$ \\
\hline O conhecimento de um fato ou informação sobre a atuação social de & $79 \%$ & \\
$\begin{array}{l}\text { uma empresa pode propiciar alterações nos preços de seus papéis } \\
\text { (ações, debentures, etc.)? }\end{array}$ & & \\
\hline
\end{tabular}

Fonte: Pesquisa ABAMEC - Comissāo Técnica de Balanço Social, 2001.

De acordo com relatório do Ethical Performance $(2000)^{47}$, o Unibanco está desenvolvendo um mapeamento do perfil das ações sociais e ambientais de empresas com ações cotadas em bolsa, para servir de parâmetro aos investidores; $\dot{E}$ a primeira instituição bancária a estruturar um setor para acompanhar o desempenho social e ambiental das empresas que atuam no país.

O Unibanco elaborou um questionário que vem sendo encaminhado para as empresas com ações negociadas na Bolsa de Valores do Estado de São Paulo (Bovespa), para obter informações sobre as ações e conduta das empresas na área ambiental e social. A meta é a cobertura total do mercado brasileiro de ações. Este relatório vem sendo encaminhado aos responsáveis nas empresas pela área que coordena a relação com investidores e com o meio ambiente. ${ }^{48}$

O relatório cobre basicamente cinco áreas: consumo de matéria-prima, nível de emissões e efluentes, gestão ambiental, política de divulgação de informações ambientais e sociais e aspectos sociais (incluindo as relações com funcionários e com a comunidade). Após o recebimento dos questionários

\footnotetext{
${ }^{47}$ Publicação mundial independente que apresenta noticias e artigos ligados às atividades de responsabilidade social das empresas.
} 
encaminhados, os analistas checam algumas informações com órgãos oficiais de controle ambiental. Os analistas do banco não atribuem notas às empresas, apenas estruturam o relatório. Este procedimento é necessário porque a avaliação por parte dos potenciais investidores varia muito em função dos diferentes ambientes institucionais e dos respectivos valores associados ao conceito de responsabilidade social. Esta variação também é decorrente do fato de haver diferentes setores nos quais as empresas analisadas se inserem.

No ano de 2001 as seguintes empresas foram alvo da pesquisa: CST, Perdigão, Sadia, Pão de Açúcar, Ultrapar, Duratex, Ambev, Aracruz, Copel, VCP e Sabesp.

Segundo o responsável pela pesquisa do Unibanco, Christopher Wells, as empresas ligadas à indústria pesada ${ }^{49}$ têm sido as mais bem preparadas para responder os questionários, especialmente aquelas que lidam com situações de risco ambiental. Entretanto, as empresas em geral não entendem o vínculo entre atuação social/ambiental e agregação de valor ao negócio, e não sabem contabilizar o balanço de custos e receitas destas ações.

A iniciativa do Unibanco foi motivada pela demanda dos gestores de fundos de investimento internacionais, especialmente fundos de pensão europeus, americanos e canadenses, interessados em conhecer os aspectos ambientais e sociais de empresas participantes no mercado acionário brasileiro.

No Brasil, a primeira iniciativa de criação de um fundo de investimento com um carteira composta de ações de empresas classificadas como socialmente responsáveis foi feita pelo Banco ABN AMRO/Real, por meio do lançamento do Fundo Ethical, em novembro de 2001.

\footnotetext{
${ }^{48}$ Em apresentação do responsável pela pesquisa do Unibanco, Christopher Wells, durante o Seminário Internacional sobre Investimentos Socialmente Responsáveis, realizado nos dias 29 e 30 de dezembro de 2001 em São Paulo e entrevista pessoal.

${ }^{49}$ Indústria que, pela sua característica, está mais sujeita a causar externalidades negativas à comunidade, como a exposição a riscos ambientais.
} 
O fundo se utiliza de dois critérios básicos para a composição da carteira: o primeiro é o critério de exclusão em que se enquadram as empresas com participação em atividades consideradas de impacto social negativo (fumo, armas, álcool, energia nuclear, pornografia e jogos de azar). A partir deste corte, o fundo busca empresas cujo desempenho equilibre expectativas financeiras, melhores práticas ambientais e sociais nos respectivos setores, e boas práticas de governança corporativa (MEIO CIRCULANTE, 2001, p.2). O Fundo Ethical tem como membros de seu conselho consultivo (com poder de veto à inclusão de empresas na sua carteira) integrantes do Instituto Ethos, do Instituto Brasileiro de Governança Corporativa e da Organização Não-Governamental "Amigos da Terra".

No periodo de novembro de 2001 a janeiro de 2002, o Fundo Ethical teve valorização de $20,6 \%$, enquanto o crescimento do IBOVESPA foi de $18,8 \%$ no mesmo período. ${ }^{50} \mathrm{~A}$ figura 8 ilustra as dimensōes do modelo seguido pelo Fundo Ethical:

Figura 8 - As dimensões do Fundo Ethical

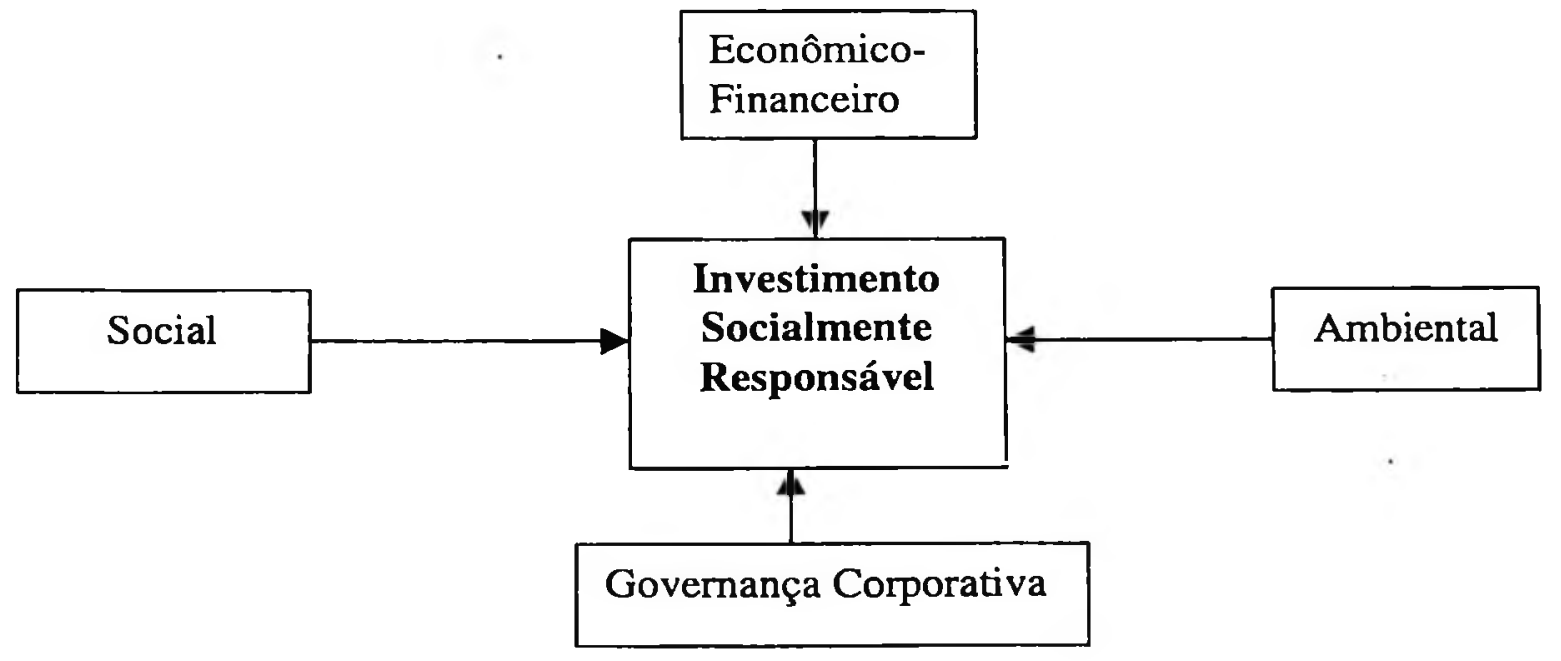

Fonte: Anotaçōes durante o Seminário Internacional sobre Investimentos Socialmente Responsáveis. São Paulo, 29 dez. 2001.

\footnotetext{
${ }^{50}$ De acordo com informação de Luiz Ribeiro, responsável pela carteira do Fundo Ethical (Revista Vocé S.A ., fevereiro de 2002).
} 
Outro tipo de benefício da ação social se dá na forma de maior facilidade de acesso a crédito, especialmente de instituições governamentais de fomento ao desenvolvimento econômico e social. De acordo com a diretora da Área Social do BNDES, Beatriz Azeredo da Silva (Leo S. - Jornal Valor Econômico, 2001), “ Algumas empresas, pelo porte que têm, fazem um investimento muito acanhado na área sócio-ambiental... Na análise dos projetos, estamos, caso a caso, estimulando esforços nessa direção". A diretora salienta ainda que os projetos que trazem vinculados programas de ação social e ambiental têm maior facilidade de tramitação no banco. Adicionalmente, os projetos de responsabilidade social têm financiamento do banco em condições favorecidas.

\subsection{2.- Melhoria de Imagem e da Reputação}

Em 1999 foi desenvolvida uma pesquisa mundial (The Millennium Pool on Corporate Social Responsibility) pela empresa Environics International (Canadá), em cooperação com as organizações The Conference Board (Estados Unidos) e The Prince of Wales Busines Leaders Forum (Reino Unido), envolvendo 25.000 entrevistas em 23 países sobre a responsabilidade social corporativa (Instituto Ethos, 2000).

No Brasil, a pesquisa foi replicada pelo Instituto Ethos (2000) em parceria com o jornal Valor Econômico, por meio da empresa Indicator Opinião Pública/SP, com 1002 entrevistas em 10 cidades das principais áreas metropolitanas do Brasil (São Paulo, Rio de Janeiro, Belém, Porto Alegre, Curitiba, Recife, Fortaleza, Salvador, Brasília e Goiânia). O objetivo destas pesquisas foi a obtenção de um maior conhecimento das percepções dos consumidores em diversos paises sobre os aspectos ligados às ações de responsabilidade social das empresas e seus desdobramentos nas relações de consumo. Conforme relatório do Instituto Ethos $(2000, p .9)$ que consolidou as pesquisas internacionais, os principais resultados destacados são: 
- $49 \%$ dos entrevistados no mundo consideram que o fator de maior influência na avaliação de uma empresa é a sua responsabilidade social, maior inclusive do que a imagem, reputação da marca e desempenho financeiro.

- Dois terços dos cidadãos entrevistados querem empresas que contribuam com amplas metas sociais e não fiquem restritas aos seus caracteristicos papéis de lucratividade, pagamento de impostos, abertura de empregos e obediência às leis.

- $50 \%$ dos entrevistados dizem estar prestando atenção ao comportamento social das empresas.

- $25 \%$ dos consumidores dizem ter prestigiado ou punido empresas com base na sua performance social.

Foi feita uma consolidação das pesquisas de âmbito nacional e internacional, para a comparação de alguns resultados. Uma das questões propostas foi relacionada com os aspectos mais importantes pelos quais é possível julgar se uma empresa é boa ou ruim. A tabela 5 destaca nas respostas os aspectos ligados à responsabilidade social e imagem/prestígio da marca.

Tabela 5 - Aspectos mais importantes para o julgamento de uma empresa

\begin{tabular}{c|c|c|c}
\hline País & $\begin{array}{c}\text { Responsabilidade Social } \\
\%\end{array}$ & $\begin{array}{c}\text { Fatores econômicos } \\
\%\end{array}$ & $\begin{array}{c}\text { Imagem/marca } \\
\%\end{array}$ \\
\hline Brasil & 56 & 13 & 34 \\
\hline Espanha & 64 & 27 & 37 \\
\hline Nigéria & 56 & 38 & 37 \\
\hline EUA & 49 & 18 & 53 \\
\hline Argentina & 47 & 21 & 46 \\
\hline México & 40 & 26 & 29 \\
\hline Alemanha & 39 & 43 & 19 \\
\hline India & 32 & 19 & 54 \\
\hline
\end{tabular}

Fonte: Instituto Ethos/Jornal Valor Econômico (Brasil), 2000; Environics, 1999 (demais países). 


\subsection{3- Demanda e Relações com o Consumidor}

Alguns estudos têm examinado o quanto os consumidores estão propensos a fazer esforços para apoiar negócios socialmente responsáveis e punir organizações irresponsáveis. Uma potencial vantagem advinda da atuação de responsabilidade social das empresas é ligada à maior propensão dos consumidores/clientes de dar preferência a empresas que tenham este tipo de comportamento, no seu processo de decisão de compra.

Outro estudo realizado por Smith (1996, apud MAIGNAN, 2001) ${ }^{51}$ aponta que $88 \%$ dos consumidores americanos pesquisados estão mais propensos a comprar de empresas socialmente responsáveis.

Maignan (2001) cita ainda pesquisa da organização Council of Foundations, destacando que $16 \%$ dos consumidores buscam, nas compras, identificar empresas que atuam socialmente (filantropia), e que $40 \%$ dos entrevistados julgaram a atividade de cidadania corporativa um forte diferencial da empresa.

Outras evidências, comparando-se diferentes países, são apresentadas com base nas pesquisas citadas do Instituto Ethos (op.cit.), conforme a tabela 6:

sI SMITH N. Craig. Corporate Citizenship and Their Critics. In: MAIGNAN, Isabelle. Consumer's Perceptions of Corporate Social Responsibilities: A cross-cultural Comparison. Joumal of Business Ethics. Netherlands: Kluwer Academic Publishers. v.30,: p. 57-72, 2001. 
Tabela 6 - Comportamento dos consumidores nos vários países em relação à premiação ou punição da empresa socialmente responsável ou irresponsável

\begin{tabular}{c|c|c}
\hline País & $\begin{array}{r}\text { Compram mais ou } \\
\text { falam bem da empresa (\%) }\end{array}$ & $\begin{array}{c}\text { Deixam de comprar } \\
\text { ou falam mal da empresa (\%) }\end{array}$ \\
\hline Brasil & 24 & 19 \\
\hline Espanha & 22 & 27 \\
\hline Estados Unidos & 46 & 28 \\
\hline Argentina & 22 & 18 \\
\hline México & 17 & 43 \\
\hline Alemanha & 37 & 34 \\
\hline Grã-Bretanha & 31 & 34 \\
\hline Itália & 25 & 10 \\
\hline India & 16 & 199 \\
\hline
\end{tabular}

Fonte - Instituto Ethos/Jornal Valor Econômico (Brasil), 2000; Environics, 1999 (demais paises).

O relatório conclui a análise comparativa dos resultados no Brasil e demais países da seguinte forma (Instituto Ethos, op.cit.pg 39) :

Os resuitados detectados em âmbito mundial foram analisados ao longo das questões e, em muitos aspectos, alguns países demonstram maior amadurecimento do consumidor em relação ao observado na pesquisa brasileira. Porém, considerando-se que no nosso país até mesmo o conceito de responsabilidade social é recente, podemos concluir que está em curso a conscientização do consumidor brasileiro para um posicionamento mais firme quanto ao seu papel de selecionar e prestigiar empresas socialmente responsáveis.

Alguns estudos, citados pelo BSR (2000) revelam que o envolvimento das empresas em atividades filantrópicas nas suas comunidades tem impacto no processo de decisão de compra dos clientes. O relatório de estudo Marketing Trends Report (1997 apud BSR 2000) destaca que 76\% dos consumidores pesquisados nos EUA em 1997 disseram que estariam propensos a trocar de marca ou produto para adquirir os de empresas que apoiam causas humanitárias, 
enquanto em estudo similar de 1993, esse percentual era de 66\%.Outro estudo, conduzido pela empresa Walker Information (BSR 2000) em 1997 mostra que 40\% dos consumidores americanos entrevistados na pesquisa disseram que o conceito de "empresa cidadã" é o fator de desempate no processo de decisão de compra, quando o consumidor está diante de produtos similares nos demais aspectos.

\subsection{4 - Percepções do Empresariado Brasileiro sobre o Voluntariado Corporativo}

O Centro de Estudos em Administração do Terceiro Setor da Universidade de São Paulo (CEATS) desenvolveu uma pesquisa em que foram arroladas algumas percepções numa amostra de 1.200 empresas, selecionadas dentre um universo de 90.000 empresas cadastradas no Centro de Integração Empresa Escola (CIEE) (FISCHER e FALCONER, 1999). Como parte da pesquisa, foram elaboradas questões referentes ao potencial benefício do voluntariado corporativo para as empresas. A tabela 7 sumariza estas questões.

\section{Tabela 7 - Percepções do empresariado sobre as ações de Voluntariado Corporativo}

\begin{tabular}{l|c|c|c}
\hline \multicolumn{1}{c|}{ Item } & Concorda & $\begin{array}{l}\text { Concorda em } \\
\text { temos }\end{array}$ & Discorda \\
\hline Melhora a imagem institucional da empresa & 79 & 8 & 0 \\
\hline Melhora o envolvimento do funcionário com a empresa & 40 & 41 & 5 \\
\hline Melhora as condições de vida na comunidade & 78 & 9 & 1 \\
\hline Melhora a relação da empresa com a comunidade & 74 & 14 & 0 \\
\hline Aumenta a motivação e produtividade dos funcionários & 34 & 43 & 9 \\
\hline Contribui para os objetivos estratégicos da empresa & 33 & 41 & 12 \\
\hline Aumenta a lucratividade da empresa & 15 & 45 & 26 \\
\hline Custa mais à empresa do que ela recebe em troca & 8 & 35 & 42 \\
\hline
\end{tabular}

Fonte: Fischer e Falconer (1999)

Fischer e Falconer (op.cit.) analisam os resultados da seguinte forma: 
Note-se que embora só $15 \%$ acreditem que o voluntariado aumenta a lucratividade da empresa, a percepção de benefícios empresariais prevalece: $79 \%$ afirmam que o voluntariado empresarial melhora a imagem institucional da empresa. Esse dado supera até a percepção de benefícios do voluntariado à comunidade (78\%). Confirmando isto, a maioria dos respondentes discorda da afirmaçāo de que um programa de voluntariado custa mais à empresa do que ela recebe em troca ( $42 \%$ contra $8 \%$ ). $\mathrm{Na}$ visão das empresas, o voluntariado é um poderoso recurso para melhorar a relação da empresa com a comunidade ( $74 \%$ concordam).

Outras evidências apontadas pelos autores nas respostas sugerem que o voluntariado empresarial é um instrumento benefíco de gestão de recursos humanos, melhora o envolvimento do funcionário com a empresa e aumenta a motivação e a produtividade. A sintese da pesquisa do CEATS sobre voluntariado apresenta as seguintes evidências (Fischer e Falconer, 1999, p.79):

- Mesmo quando as empresas desvinculam suas estratégias negociais das estratégias de atuação social elas observam resultados positivos para seus negócios, advindos do exercício das atividades de caráter social;

- Quando a atuação social da empresa compreende o envolvimento dos funcionários em trabalhos voluntários, os ganhos de imagem institucional e de melhoria do clima organizacional são evidentes;

- Se o voluntariado empresarial possibilitar o emprego de conhecimentos especializados, competências profissionais e experiência de trabalho das pessoas, tenderá a provocar maior satisfação nos funcionários engajados;

- Quando há sinergia de missão e estratégias do negócio com as escolhas de atuação social da empresa é possível otimizar o emprego dos recursos e tornar o convite ao voluntariado mais atraente e factivel. 


\subsection{5 - Aspectos institucionais - O Balanço e a Certificação Social}

Tramita no Congresso Nacional Brasileiro em 2002 um projeto de lei número 3116 que estabelece a obrigatoriedade de publicação do Balanço Social por empresas privadas com mais de 100 funcionários e por todas as empresas públicas ou concessionárias e permissionárias de serviços públicos (BNDES, 2000). Independentemente da obrigatoriedade, diversas empresas no Brasil já elaboram o Balanço Social para distribuição ao conjunto de seus stakeholders.

No panorama internacional, várias iniciativas de relatórios sociais já estão implementadas (Instituto Ethos, 2001). A tabela 8 apresenta o cenário em alguns países, segundo o enfoque dado pelo Balanço Social.

\section{Tabela 8 - Balanço Social - Panorama Internacional}

\begin{tabular}{|c|c|}
\hline Pais & Balanço Social - Enfoque \\
\hline Estados Unidos & $\begin{array}{l}\text { Énfase aos consumidores/clientes e à sociedade em } \\
\text { geral;qualidade dos produtos, controle da poluição, } \\
\text { contribuição da empresa às obras culturais, transportes } \\
\text { coletivos; benefícios à coletividade; abordagem de } \\
\text { caráter ambiental }\end{array}$ \\
\hline Holanda & $\begin{array}{l}\text { Enfase nas informações sobre as condições de } \\
\text { trabalho. }\end{array}$ \\
\hline Suécia & Énfase nas informaçōes aos empregados. \\
\hline Alemanha & $\begin{array}{l}\text { Enfase nas condições de trabalho e aos aspectos } \\
\text { ambientais }\end{array}$ \\
\hline Inglaterra & $\begin{array}{l}\text { Ënfase no conceito de stakeholders, relatórios } \\
\text { abrangentes. }\end{array}$ \\
\hline França & $\begin{array}{l}\text { Enfase nas informações aos empregados, nível de } \\
\text { emprego, remuneração, condições de trabalho e } \\
\text { formação profissional. }\end{array}$ \\
\hline
\end{tabular}

Fonte: DE LUCA, Márcia Martins Mendes, 1998 apud Instituto Ethos - Guia de Elaboração de Relatório e Balanço Anual de Responsabilidade Social Empresarial, 2001. 
Do ponto de vista legal, outro aspecto de relevância são os incentivos fiscais para as empresas envolvidas em atividades sociais. No Brasil, as empresas (pessoas jurídicas) podem usufruir de incentivos fiscais até o limite de $2 \%$ do imposto de renda devido, a partir de cálculo feito com base no lucro real, no caso de efetuarem doações a entidades sem fins lucrativos e reconhecidas como de utilidade pública, definidas conforme legislação federal de 1995 (Lei 9249/95) (BNDES, 2000). No caso de doações a projetos culturais, a dedução vai até o limite de $4 \%$ do imposto devido, e para doações direcionadas ao Fundo da Criança e do Adolescente o limite é de $1 \%$.

Quanto à certificação social, estão sendo criadas normas internacionais por organizações não-governamentais e organismos multilaterais, visando ao desenvolvimento e consolidação de padrões e indicadores auditáveis de certos aspectos éticos e de responsabilidade social (BNDES, 2000).

Da mesma forma que as normas ISO 9000 e ISO 14000 certificam respectivamente a qualidade do processo e o respeito ao meio ambiente das empresas, as normas BS 8800 e SA $\mathbf{8 0 0 0}$ foram criadas para certificar aspectos de caráter social das empresas.

A norma BS 8800 certifica empresas que atingem padrões de garantia à saúde e segurança do trabalhador. A norma SA 8000 , baseada nos princípios da Organização Internacional do Trabalho (OIT), certifica aspectos ligados à conduta das empresas no que se refere aos direitos humanos e trabalhistas no ambiente empresarial.

A norma SA é coordenada pela Social Accountability International, uma organização não-governamental com sede nos Estados Unidos. O selo tem validade de um ano, e deve ser emitido por orgãos certificadores cadastrados na Social Accountability International. 
Os principais itens constantes da norma são (Revista Exame, 2001):

Trabalho Infantil: proibição de contratação de crianças menores de 15 anos. Os funcionários nesta faixa de idade não poderão ser demitidos e a empresa deverá prover a sua educação.

Liberdade de associação: protege o direito dos trabalhadores de se associar a grupos e sindicatos.

Discriminação: proibição de discriminação baseada em nacionalidade, religião, raça, cor, sexo, orientação sexual e deficiência física.

Horário de trabalho: no máximo 44 horas. As horas extras devem ser voluntárias e temporárias.

Práticas disciplinares: proibição de punições físicas, coerção e abuso verbal aos trabalhadores.

Comunicação: a política de responsabilidade deve ser documentada e divulgada aos trabalhadores.

A utilização da certificação possui relação intrínseca com a busca de reputação por parte das empresas. Zylbersztajn (2000) cita que:

...aparentemente o incentivo mais eficaz para a adoção de normas éticas, sempre que exista um risco potencial de efeito sobre o valor da empresa. Para precaver-se de tais riscos, muitas organizações adotam certificação independente para aferir a sua credibilidade em termos da conduta ética voltada para aspectos sociais, ambientais e tecnológicos. 
No próximo capítulo serão apresentados os estudos de caso deste trabalho. Após a descrição dos casos, os resultados serão sistematizados em três tópicos:

- A análise dos casos, procurando-se estabelecer relações com o referencial teórico apresentado ao longo do trabalho (Nova Economia das Instituições e Teoria da Agência);

- A análise das evidências que sustentem as hipóteses de pesquisa apresentadas;

- A classificação das empresas em três modelos citados no estudo: Fombrun (2000), Quazi e O'Brien (2000) e o modelo sugerido pelo autor. 


\section{CAPÍTULO 4 - ANÁLISE DOS ESTUDOS DE CASO}




\section{1 - CASO 1 - GRUPO ORSA}

Neste estudo de caso serão consideradas duas empresas que compõem atualmente o Grupo Orsa:

- Orsa Celulose, Papel e Embalagens

- Jari Celulose

\subsection{1. - Informações Básicas}

\subsubsection{1 - Orsa Celulose, Papel e Embalagens}

A Orsa iniciou suas atividades em setembro de 1981, formada por quatro sócios com experiências anteriores no ramo de papelão ondulado, que montaram uma cartonagem no bairro de Vila Zelina, em São Paulo. A empresa teve um expressivo crescimento nas duas últimas décadas, e atualmente é o terceiro produtor nacional de caixas e chapas de papelão ondulado. Entre 1994 e 1999, a produção do grupo teve um crescimento médio anual de $14 \%$ ao ano, superior à média do setor. A tabela 9 ilustra o crescimento da Orsa.

Tabela 9 - Expedição de Caixas e Chapas de Papelão Ondulado no Brasil (1000 ton)

\begin{tabular}{l|l|l|l|l|l|l}
\hline & 1995 & 1996 & 1997 & 1998 & 1999 & 2000 \\
\hline ORSA & 83 & 97 & 107 & 117 & 147 & 173 \\
\hline TOTAL Brasil & 1350 & 1475 & 1590 & 1615 & 1676 & 1756 \\
\hline Market-share ORSA (\%) & 6,1 & 6,6 & 6,7 & 7,2 & 8,8 & 9,9 \\
\hline
\end{tabular}

Fonte: Site empresa ( www.grupoorsa.com.br) / dados da ABPO.

No ano de 1986 o grupo construiu a sua primeira unidade industrial para a produção de chapas e caixas de papelão ondulado, em Suzano/SP. A partir de 
então o Grupo passou por um período de expansão acentuada, devido às aquisições, verticalizando totalmente suas operações.

Em 1990 o Grupo Orsa adquiriu a unidade de papel Kraftliner da família Sguario, em Nova Campina/SP. Nesta unidade produz-se a celulose de fibra longa não branqueada, a partir de cavacos de madeira (pinus), e ato contínuo o papel kraftliner. Em 1992 o grupo incorporou a empresa J.Bresler S/A, produtora de papel reciclado em Paulínia/SP. Em 1999 o Grupo construiu outras unidades de produção de caixas e chapas de papelão ondulado em Rio Verde/GO e Manaus/AM.

Em 2001 a ORSA contava com quatro unidades produtivas de papel e papelão ondulado, sendo duas no estado de São Paulo (Suzano e Paulínia), uma no estado de Goiás (Rio Verde) e uma no estado do Amazonas (Manaus). Possui duas unidades de produção de papel (uma em Itapeva e uma em Paulínia).

O fluxo de produção se inicia com o corte de pinus da área florestal localizada em Itapeva/SP. Na seqüência, é produzido o papel kraft, na planta industrial de Nova Campina/SP. O papel kraft abastece as unidades produtoras de caixas e chapas de papelão, em Suzano, Paulínia, Rio Verde e Manaus. O excedente de papel é vendido nos mercados interno ou externo. Na unidade de Paulínia existe também uma linha de produção de papel reciclado, a partir de aparas de papel que são recompradas no mercado ${ }^{52}$, e que se transformam em papel testliner ou miolo, utilizados como insumos para produção das caixas e chapas de papelão. A capacidade de produção de papéis da empresa é de $276 \mathrm{mil}$ toneladas/ano, e cerca de $20 \%$ da produção de papel kraftliner é exportada.

O faturamento da Orsa em 2000 foi de US\$173 milhões (Revista Exame, "Maiores e Melhores", 07/2001). A empresa possui cerca de 1.500 funcionários diretos e 1.000 indiretos em sua área florestal e nas unidades industriais. No setor

\footnotetext{
${ }^{52}$ As aparas constituem o volume de papelão recolhido no mercado para ser reciclado.
} 
de papelão ondulado a Orsa era em 2001 a terceira maior empresa no mercado nacional, com cerca de $10 \%$ de fatia do mercado, atrás da Klabin (capital nacional) que detém cerca de $31 \%$ do mercado, e da Rigesa (capital americano), com cerca de $18 \%$ do mercado.

O mercado de papelão ondulado é formado por diversos setores produtivos que usam as caixas e chapas de papelão como embalagem. Os principais setores são as indústrias de alimentos (32\%), de produtos químicos $(9 \%)$, a fruticultura $(4 \%)$, a indústria metalúrgica $(4 \%)$, de eletroeletrônicos $(3 \%)$, de bebidas $(3 \%)$ e têxteis (3\%). Entre os principais clientes estão empresas como: Nestlé, Multibrás, Gessy lever, Ambev, Bombril, Arisco, Perdigão, VCP, Parmalat, LG, Procter Gamble, Cia Suzano e Ripasa.

\subsubsection{2 - Jari Celulose}

No ano 2000 o Grupo Orsa assumiu o controle da empresa Jari Celulose, localizada na região norte do país, entre os Estados do Pará e do Amapá. A Jari é uma empresa conhecida no Brasil por sua história peculiar ${ }^{53}$. Esta história recente tem um marco em 1967, quando o empresário americano Daniel Ludwig lançou a idéia de um ambicioso projeto de reflorestamento no meio da Amazônia, com o propósito central de produção de celulose. A empresa possui uma área de 1.734.606 hectares, na maior parte coberta pela floresta amazônica.

O projeto ao longo dos anos enfrentou diversos problemas, chegando próximo de situação falimentar, até a empresa ser incorporada ao Grupo ORSA em 2000, que assumiu o controle da empresa renegociando uma dívida de cerca de US $\$ 400$ milhões com os principais bancos credores liderados pelo BNDES. $O$

\footnotetext{
${ }^{53} \mathrm{O}$ "Projeto Jari" tem uma trajetória singular no ambiente empresarial do Brasil. Além da polêmica em tomo da sua viabilidade económica e dos aspectos políticos, o Projeto Jari tem peculiaridades históricas, como a saga em 1978 do transporte da planta industrial e da usina termoelétrica, pesando 30 mil toneladas cada, desde o Japāo, onde foram construídas, até a margem do Rio Jari, onde foram assentadas. A viagem durou três meses através dos oceanos Pacífico, Indico e Atlântico.
} 
Grupo ORSA assumiu o controle com o desafio de equilibrar a dívida e implementar um novo plano estratégico para reerguer a empresa.

A Jari gera 950 empregos diretos e 2.500 indiretos (prestadores de serviços). Produz cerca de 330.000 ton/ano de celulose de fibra curta branqueada, com faturamento em 2000 de US\$179,3 milhões. A maior parte da produção (cerca de $85 \%$ do volume) é direcionada para fábricas de papel no mercado externo (Europa, EUA e Ásia). Os restantes $15 \%$ são vendidos para fábricas de papel no Brasil.

A tabela 10 apresenta 0 ranking das empresas produtoras de celulose de mercado ${ }^{54}$ no Brasil, de acordo com a capacidade instalada em 2001.

Tabela 10 - Principais empresas produtoras de celulose de mercado no Brasil (2001 - capacidade instalada)

\begin{tabular}{l|c|c}
\hline Empresa & $\begin{array}{c}\text { Volume } \\
(1000 \text { ton })\end{array}$ & $\%$ \\
\hline Aracruz & 1.330 & 36 \\
\hline Cenibra & 860 & 23 \\
\hline Bahia Sul & 400 & 11 \\
\hline Jari & 330 & 9 \\
\hline VCP & 325 & 9 \\
\hline Riocell & 285 & 8 \\
\hline Outros & 195 & 4 \\
\hline Total & 3725 & 100 \\
\hline
\end{tabular}

Fonte: Jari Celulose.

\footnotetext{
${ }^{54} \mathrm{O}$ termo "celulose de mercado" é designado para a parte da celulose comercializada no mercado, nāo incluindo a produção para utilização própria, no caso de empresas integradas produtoras de celulose e papel.
} 


\subsection{2 - As atividades de responsabilidade social do Grupo Orsa}

No ano de 1993, parte dos acionistas do Grupo Orsa deixou a sociedade. Um dos motivos da cisão foi a decisão do acionista principal (Sérgio Garcia Amoroso) de desenvolver um projeto de cunho social. Esta decisão prevaleceu, Sérgio Amoroso e seus irmãos assumiram a parte dos sócios antigos e lançaram as bases do projeto social. Em 1994 foi criada a Fundação Orsa, com dotação inicial e comprometimento de $1 \%$ do faturamento bruto das unidades componentes do grupo.

Ambas as empresas (Orsa e Jari) possuem ações próprias de responsabilidacie social, internalizadas nas suas estruturas organizacionais, especialmente ligadas a questões do meio ambiente, infra-estrutura e políticas de recursos humanos que visam à utilização de deficientes, entre outras ações. Entretanto, é por meio da ação da Fundação Orsa que o Grupo se destaca em suas ações sociais. A Fundação Orsa é o braço social do Grupo Orsa, operacionalizando projetos próprios.

No exercício da Fundação, as ações sempre estiveram voltadas para a comunidade externa, evitando-se que elas ocorressem em benefício dos próprios funcionários. As ações de responsabilidade social da Orsa desde sua origem estiveram dissociadas da estratégia de negócios da empresa. A Fundação não segue a orientação estratégica da empresa, no sentido da escolha de sua missão, objetivos, público-alvo e atuação geográfica. Os projetos implementados pela Fundação são definidos por sua própria estrutura organizacional e apresentados para aprovação aos instituidores e conselho. Uma outra característica é que a Fundação Orsa tem condições de desenvolver projetos de longo prazo com maior previsibilidade, uma vez que seu orçamento é baseado no faturamento das empresas mantenedoras, não no lucro. Assim, mesmo que em determinado ano as empresas venham a ter prejuizo, o valor alocado para a Fundação está garantido, com base no faturamento. 
A Fundação Orsa recebe anualmente $1 \%$ do faturamento bruto das duas principais empresas do Grupo Orsa (Orsa Celulose, Papel e Embalagens e Jari Celulose). $O$ recurso oriundo da empresa Orsa tem a sua destinação não ligada a regiões geográficas específicas. No caso dos recursos oriundos da Jari Celulose, devem ser integralmente aplicados pela Fundação na região do Jari.

O crescimento da dotação orçamentária da Fundação desde 1994 foi expressivo, acompanhando o crescimento exponencial do Grupo Orsa. Em 1994, - montante de recursos da Fundação foi de aproximadamente R\$225 mil. Já em 2000, o montante chegou a mais de $R \$ 6$ milhões, e o orçamento previsto para 2001 foi de $R \$ 9,7$ milhões (tabela 9).

A missão da Fundação ORSA desde o seu início esteve ligada às gerações futuras, no sentido de proteger crianças e adolescentes em situações de risco pessoal e social, resgatar a cidadania e promover a sua inclusão na sociedade civil. A Fundação é organizada em núcleos específicos (Saúde, Educação, Promoção Social e Voluntariado).

A Fundação ORSA possui vários projetos sociais distribuídos nas suas áreas funcionais, desenvolvidos de forma multidisciplinar e constituindo a essência dos projetos denominados "Formação", que funcionam como espaços interativos para o desenvolvimento dos projetos. Estes projetos se distribuem em vários locais do país:

$$
\begin{aligned}
& \text { Formação I - Campinas } \\
& \text { Formação II - Suzano/SP } \\
& \text { Formação III - Monte Dourado/PA } \\
& \text { Formação IV - Guiratinga/MT } \\
& \text { Formação V - Laranjal do Jari/AP } \\
& \text { Formação VI - Vitória do Jari/AP } \\
& \text { Formação VII - Carapicuiba/SP }
\end{aligned}
$$


Nota-se que, em princípio, a Fundação Orsa não tem qualquer relação intrínseca com as atividades de negócios do Grupo, especialmente com a empresa Orsa. A Fundação desenvolve açōes entre o seu público alvo, sem vinculo direto com as comunidades onde a empresa possui plantas industriais.

Além disto, tem sido enfatizado pelo controlador da empresa e instituidor da Fundação, Sérgio Garcia Amoroso, que as ações da Fundação não têm por objetivo atingir os funcionários e demais stakeholders diretamente ligados à empresa, mas visam a atender à população externa, constituída pelas crianças e adolescentes em situação de risco social e pessoal. Já no caso da Jari Celulose, dada a atuação centralizada da Fundação na comunidade onde a empresa opera, inevitavelmente a relação fundação-empresa passa a ser mais estreita, levando à necessidade de maior integração do planejamento estratégico de ambas. A Figura 09 apresenta esquematicamente a relação entre a Orsa, a Jari e a Fundação.

Figura 09 - Relação entre a Orsa, a Jari e a Fundação Orsa

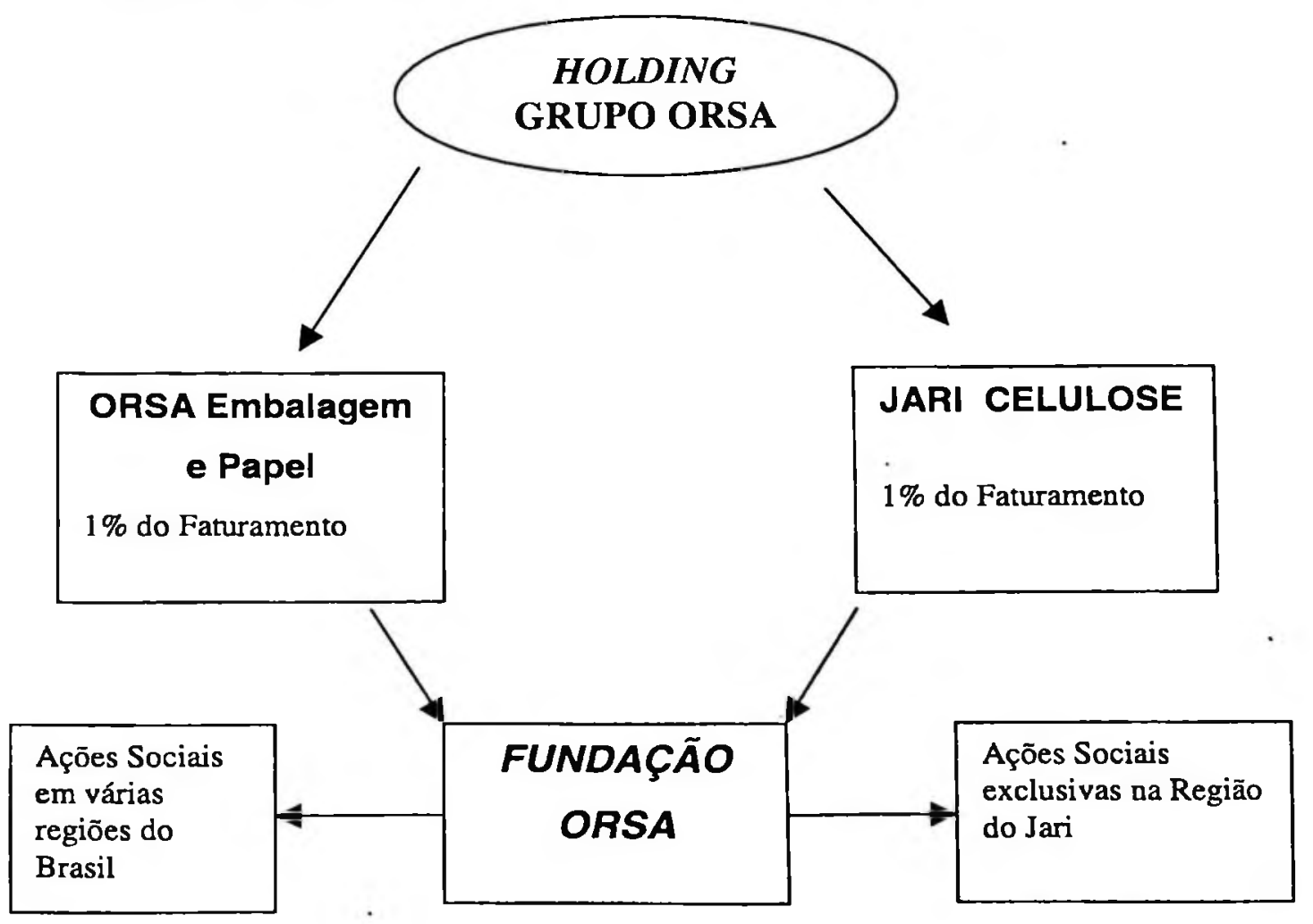


A tabela 11 apresenta o valor do investimento social e o demonstrativo de atendimentos da Fundação Orsa, no periodo entre 1994 e 2001.

Tabela 11 - Investimentos e número de assistências da Fundação Orsa, 1994-2001

\begin{tabular}{|c|c|c|c|c|c|c|c|c|}
\hline & 1994 & 1995 & 1996 & 1997 & 1998 & 1999 & $2000^{\star}$ & $2001^{* \star}$ \\
\hline $\begin{array}{l}\text { Valor investido } \\
\text { (R\$) }\end{array}$ & 224.803 & 1.468 .048 & 3.340 .479 & 2.718 .954 & 3.433 .100 & 3.496 .227 & 6.033 .510 & 9.750 .000 \\
\hline $\begin{array}{l}\text { Crianças e adolescentes } \\
\text { assistidos }\end{array}$ & 3073 & 64530 & 55773 & 181263 & 210265 & 290165 & 377215 & 450000 \\
\hline
\end{tabular}

Fonte: Fundaçāo Orsa - Relatório Anual, 2001.

*A partir de 2000 está contabilizado 1\% do faturamento da Jari celulose.

** estimativa

A aquisição da Jari Celulose pelo Grupo Orsa praticamente dobrou o orçamento da Fundação para investimento em programas sociais. Entretanto, problemas específicos provenientes do antigo relacionamento da empresa com a comunidade constituem grandes desafios para a implementação da filosofia da Fundação na região do Jari. Tais desafios são derivados da cultura paternalista e das ingerências políticas que regeram as relações anteriores com a comunidade e que levaram a ações de cunho assistencialista que a empresa usualmente desempenhou na região.

No passado, a Jari, como empresa pioneira a se estabelecer na região, foi responsável pelo suprimento de toda a infraestrutura básica nas principais cidades que constituem o chamado "Projeto Jari" (Laranjal do Jari, Vitória do Jari e Almeirim (distrito de Monte Dourado), onde se situa a planta industrial e a vila residencial dos funcionários da empresa). Praticamente hegemônica na região, toda a população em torno do projeto Jari (cerca de 50.000 pessoas) dependia e 
ainda depende direta ou indiretamente do desempenho da empresa para sobreviver. ${ }^{55}$ Mas a Jari enfrentou enormes problemas financeiros na década de 90 , e quase encerrou suas atividades. A incorporação da empresa pelo Grupo Orsa representa a oportunidade de reconstrução e retomada da atividade de negócios, com novos investimentos, e novas perspectivas sociais e econômicas para toda a região. Conseqüentemente, as expectativas criadas na região em relação à performance, tanto da Jari como da Fundação Orsa são muito grandes.

Um aspecto importante a ser explorado pela Jari é o potencial impacto positivo das ações da Fundação na imagem e reputação da empresa. A Jari é um global player no mercado mundial de celulose, e busca resgatar a imagem desgastada pelas últimas administrações, por meio de uma reputação de empresa socialmente responsável, alinhando suas práticas comerciais com as novas práticas sociais e ambientais na região do Jari. ${ }^{56}$

\subsection{3. - A Estrutura Organizacional para lidar com as atividades de responsabilidade social - $O$ exemplo da Jari.}

Uma questão relevante é a comparação das diferenças entre o desenvolvimento das ações sociais da Jari anteriormente e o da Fundação Orsa atualmente. No caso da Jari, como principal empresa operando na região, o envolvimento de alguns dos antigos gestores da empresa com a comunidade era caracterizado por relações paternalistas e assistenciais, distorcidas em muitos aspectos. Os gestores da empresa assumiam poderes políticos e sociais nas relações com a comunidade, causando sérios problemas de agência.

Em outras palavras, faziam supostamente "ações sociais" com recursos da empresa, e via de regra as ações desempenhadas eram pouco efetivas para a resolução dos reais problemas sociais da região. Não havia planejamento ou controle destas ações, que eram realizadas de forma dispersa e sem critérios

\footnotetext{
${ }^{55}$ Entrevista com Cristóvão Lins, relaçōes públicas da Jari Celulose.
} 
claros. Muitas ações eram injustificadas tanto do ponto de vista social como do econômico, gerando apenas elevados custos para a empresa.

Além destas ações sem critérios, a empresa desenvolvia (e ainda parcialmente desenvolve) atividades típicas do setor público, como a administração do aeroporto local, tratamento de água, suprimento de energia, entre outras. Estas atividades fizeram sentido pelo fato de a empresa ser pioneira em região remota e com escassa infra-estrutura básica. Esta situação foi reportada em várias entrevistas na região do Jari. Os habitantes locais viam a Jari como uma organização poderosa, "onipotente", com poderes típicos da esfera pública, substituindo em muitos aspectos as tarefas da prefeitura, secretarias municipais e estaduais.

Gradativamente, a empresa começou a se desvincular destas atividades. As ações de cunho social da Jari estão sendo canalisadas para a Fundação Orsa. "O papel da Jari é produzir celulose", enfatiza o presidente da empresa, José Cláudio Sardinha, "as ações sociais são funções da Fundação Orsa, com os recursos repassados provenientes de $1 \%$ do faturamento da Jari". ${ }^{57}$

A separação de funções entre a empresa Jari e a Fundação Orsa, segundo os depoimentos parece ter sido benéfica para ambas, reduzindo ineficiências decorrentes de custos de "agência" oriundos do desalinhamento de interesses entre os principais (acionistas) e agentes (gestores).

A Fundação tem uma função-objetivo bastante clara. Com base em estudo realizado, foram mapeados os principais problemas da região, como consumo de drogas, prostituição, violência, doenças, problemas sanitários e ambientais. As ações sociais implementadas pela estrutura organizacional da Fundação são mais efetivas e focalizadas, possibilitando resultados mais visiveis em termos de melhorias sociais para crianças e adolescentes em situação de risco na região.

\footnotetext{
${ }^{56}$ Depoimento de Ana Maria Vianna, diretora comercial da Jari Celulose.
} 
Este exemplo constitui uma evidência empírica que reforça a opção $B$ apresentada no referencial teórico (estrutura organizacional especializada para lidar com ações sociais, sob controle hierárquico da firma, por meio de seus instituidores).

\subsection{4 - A Integração das ações entre a Fundação e as Empresas (Orsa e} Jari)

No final do ano 2000, após a consolidação do controle da Jari, o Grupo Orsa iniciou um processo decisivo de profissionalização da gestão. $O$ acionista majoritário (Sergio Amoroso) substituiu os membros familiares em cargos de direção na empresa Orsa, e iniciou um processo de profunda reestruturação organizacional. Este processo em curso se dá no âmbito da Orsa, da Jari e da Fundação Orsa. A holding Grupo Orsa, passou a estruturar-se operacionalmente para ter uma atuação na definição estratégica e no monitoramento das empresas.

Como direcionamento futuro, existe a perspectiva de o Grupo Orsa vir a buscar alavancar o seu crescimento por meio de fusões ou alianças estratégicas, ou mesmo pela abertura de capital da empresa Orsa, dada a limitação do potencial do Grupo em auto-financiar o seu crescimento, em razão dos investimentos realizados. Neste sentido, o Grupo está desenvolvendo um processo de gestão estratégica com foco na transparência e na eficiência organizacional, visando a atingir um melhor nível de governança corporativa.

Como destacado, não houve originalmente um planejamento integrado das atividades da Fundação Orsa com a empresa original (Orsa), e mais recentemente com a Jari. A Fundação, embora dependente financeiramente do Grupo Orsa, sempre atuou com independência programática para desenvolver seus próprios projetos sociais.

\footnotetext{
${ }^{57}$ Entrevista pessoal.
} 
A partir de 2001, iniciou-se a implementação de um processo de gestão estratégica na Fundação, paralelamente a um processo similar nas empresas do Grupo Orsa, com a priorização e implementação de vários projetos estratégicos. Entre os projetos priorizados existe um especificamente delineado para definir estratégias de ação, visando a que integrem e explorem sinergias entre a Fundação Orsa e as empresas. Com este projeto, o grupo Orsa pretende atrelar de forma mais intensa o papel social da Fundação à sua imagem corporativa. Um outro objetivo é a utilização do voluntariado corporativo, que motiva o envolvimento sistemático de funcionários das empresas do Grupo nos projetos sociais da Fundação.

\subsection{5 - Evidências de retorno à imagem corporativa}

Alguns fatos ilustram o reconhecimento às ações da Fundação Orsa e o Grupo Orsa como as premiações recebidas de instituições diversas:

- A Fundação Orsa recebeu o prêmio Top Social 2000 da ADVB (Associação dos Dirigentes de Vendas do Brasil), como destaque na área de atuação social;

- A Fundação Orsa recebeu o Prêmio Eco 2000, da Câmara Americana de Comércio de São Paulo, pelo programa de formação de profissionais de educação infantil;

- A Fundação Orsa recebeu a medalha Anísio Teixeira, da Prefeitura do Município de Porto Seguro/BA, pelo programa de formação de profissionais de educação infantil;

- O Grupo Orsa recebe o prêmio de Destaque Especial 2000 do PNBE (Pensamento Nacional das Bases Empresariais);

- O Grupo Orsa foi incluído em 2000 no Guia Exame de Boa Cidadania Corporativa, como empresa de destaque em projetos sociais. O Grupo Orsa foi incluído em 2001 no Guia Exame das 100 melhores empresas para você trabalhar no Brasil. 
Na classificação da revista Exame, a pontuação segundo os critérios para escolha das 100 melhores, conforme a tabela 12, foi a seguinte:

Tabela 12 - Pontuação obtida pela Orsa para a sua inclusão entre as 100 melhores empresas para se trabalhar da revista Exame.

\begin{tabular}{l|c}
\hline Item & Pontuação \\
\hline Remuneração & $\mathrm{XX}$ \\
\hline Benefícios & $\mathrm{XX}$ \\
\hline Oportunidades de carreira e treinamento & $\mathrm{XX}$ \\
\hline Segurança e confiança na gestão & $\mathrm{XX}$ \\
\hline Orgulho do trabalho e da empresa & $\mathrm{XXXX}$ \\
\hline Clareza e abertura na comunicação interna & $\mathrm{XXX}$ \\
\hline Camaradagem no ambiente de trabalho & $\mathrm{XXXX}$ \\
\hline Responsabilidade social & $\mathrm{XXX}$ \\
\hline
\end{tabular}

Fonte: Revista Exame - 100 melhores empresas para você trabalhar, 2001.

Pontuação máxima - XXXXX

Pontuação mínima - $X$

Tanto a empresa Orsa como a Jari são produtoras de bens intermediários. Não produzem bens de consumo final. $\mathrm{Na}$ visão dos entrevistados, os maiores benefícios da ação social advêm do reconhecimento e da motivação interna dos funcionários e da sociedade em geral. Os entrevistados não percebem relação direta entre as ações sociais com o aumento das vendas dos produtos das empresas. Entretanto, no longo prazo a Jari possui um maior potencial a ser explorado decorrente das ações sociais, uma vez que a maior parte da sua produção está direcionada para o mercado externo, especialmente europeu, mais exigente para com o comportamento empresarial relacionado aos aspectos sociais e ambientais. 


\section{2 - CASO 2 - NESTLÉ}

\subsection{1. - Informações básicas}

A Nestlé é uma empresa multinacional de origem suiça, presente nos cinco continentes, com cerca de 220 mil funcionários em todo o mundo. A empresa foi criada em 1867, por Henri Nestlé, com o lançamento da Farinha Láctea Nestlé, alimento para crianças à base de cereais e leite. A Nestlé atualmente tem um faturamento mundial consolidado da ordem de US $\$ 52$ bilhões, com 425 fábricas.

No Brasil, a empresa se instalou em 1921, com uma unidade industrial em Araras/SP. Atualmente possui cerca de 13 mil funcionários, em 22 unidades industriais, com faturamento em 2000 de US $\$ 2,57$ bilhões.

A linha de produtos é extensa, com cerca de 450 itens de uma grande variedade de produtos: leites, leites infantis, especialidades dietéticas, alimentos infantis, culinários, caldos, sopas, temperos, molhos, massas, chocolates, congelados, cereais matinais, biscoitos, balas, confeitos, achocolatados, cafés, iogurtes, sobremesas, sucos, sorvetes, entre outros. A empresa possui também uma linha de food-service (alimentação fora do lar) e outra de alimentos para animais domésticos.

A Nestlé lidera o ranking nacional da indústria agregada de alimentos. A tabela 13 apresenta as principais empresas do setor, de acordo com sua receita operacional bruta em 2000 (US\$ milhões). 
Tabela 13 - Classificação das empresas do setor de alimentos no Brasil, 2000

\begin{tabular}{l|c}
\hline Empresa & Receita operacional bruta (US\$ milhões) \\
\hline Nestlé & 2574,8 \\
\hline Bunge & 1961,9 \\
\hline Sadia & 1740,6 \\
\hline Cargill & 1664,0 \\
\hline Perdigão & 1037,9 \\
\hline RMB & 791,6 \\
\hline Parmalat & 731,6 \\
\hline Kraft Lacta & 513,3 \\
\hline Fleischmann Royal Nabisco & 508,2 \\
\hline Seara & 496,0 \\
\hline
\end{tabular}

Fonte: Revista Exame - ed. Especial, 07/2001 - Maiores e Melhores.

\subsection{2 - As atividades de Responsabilidade Social da Nestlé}

A Nestlé tem algumas diretrizes gerais que são seguidas por todas as suas filiais no mundo todo, consolidadas em um documento-padrão intitulado "Princípios Nestlé de Gestão Empresarial'. Neste documento explicita-se a orientação geral da empresa de criar valor para os seus stakeholders:

A finalidade dos negócios da Nestlé, exercidos por suas gerências e colaboradores de todos os niveis, é fabricar e vender seus produtos de forma a criar valor sustentável a longo prazo para os consumidores, acionistas, colaboradores, parceiros comerciais e aos sistemas econômicos dos países onde opera" (Nestlé, 1996, p.4).

As principais orientaçōes referem-se à obrigação dos cumprimentos legais e à observância de recomendações como os direitos básicos da Organização Internacional do Trabalho (OIT) e do Código Internacional de Comercialização de Substitutos do Leite Materno, da Organização Mundial de Saúde (OMS). 
A Nestlé impõe um código básico de ética para balizar as suas ações em alguns temas como a relações da empresa com os consumidores, a proteção ambiental, não se utilizar do trabalho infantil, manter ambiente de trabalho sem discriminações, relações éticas com fornecedores e parceiros comerciais. Estas premissas básicas devem ser seguidas por todas as filiais no mundo.

Cumprindo essas diretrizes básicas, cada filial tem autonomia para desenvolver programas específicos e incluir outras ações de responsabilidade social, desde que não conflitantes com as diretrizes estabelecidas. No Brasil, a Nestlé investe em programas nas áreas de educação, saúde e cultura, além do tratamento específico às questões ambientais.

No ano de 1981 a Nestlé criou no Brasil um programa social denominado "ação comunitária". O objetivo era o apoio a comunidades carentes, com investimentos em reformas de creches, centros comunitários e outras benfeitorias. Este programa era viabilizado em parceria com os funcionários: a empresa destinava igual montante ao que era doado pelos funcionários. Não havia, entretanto, uma orientação estratégica centralizada pela organização, e com o passar dos anos, o programa foi perdendo foco e controle, de acordo com depoimento recolhido na empresa ${ }^{58}$.

Em junho de 1999, a empresa mudou a sua estratégia de ação social no Brasil. As ações sociais foram estruturadas na área de assuntos corporativos, incorporando as atividades da Fundação Nestlé de Cultura, que desenvolve programas específicos na área cultural, com incentivos da Lei Rouanet.

O portfólio dos principais programas sociais desenvolvidos pela Nestlé são:

\section{a) O Programa Nutrir}


Em dezembro de 1999 foi criado o "Programa Nutrir", que constitui o "guarda chuva" das ações sociais da empresa. O foco é a área de alimentação e Nutrição, com projetos educativos para um público-alvo de crianças de 5 a 14 anos. A essência do programa é baseada na ação voluntária dos funcionários. A empresa contabiliza cerca de 6.000 funcionários que doam recursos e 1.250 que atuam dedicando tempo ao trabalho nas às comunidades. ${ }^{59}$ Para cada real de recurso doado, a empresa arca com o equivalente. Ao todo, o montante atualmente arrecadado para o programa Nutrir atinge $\mathrm{R} \$ 1$ milhão.

O escopo do Programa Nutrir é a educação nutricional e a prevenção da desnutrição, por meio da transmissão de conceitos de higiene, nutrição e aproveitamento de alimentos. O programa tem uma alta sinergia com a atividade de negócios da empresa, e conseqüentemente com os conhecimentos técnicos dos funcionários voluntários.

\section{b) Programa Viagem Nestlé pela Literatura}

Este programa envolve milhares de jovens do ensino médio de escolas públicas e particulares, e visa a estimular a leitura e o espírito crítico. O programa atinge cerca de 8,8 mil escolas, 17.600 professores e 176.000 alunos, que participam do concurso promovido pela empresa. $O$ projeto tem apoio do Ministério da Cultura, e objetiva estimular jovens a pesquisar, ler e escrever. No ano de 2001, na sua terceira edição, o programa recebeu investimentos de $R \$ 3$ milhões, com a distribuição de 90 mil livros para estudantes de todo o país.

\section{c) Meio Ambiente}

A Nestlé possui um sistema de monitoramento do meio ambiente, seguindo as normas internacionais da empresa e o padrão legal vigente no Brasil. A

\footnotetext{
${ }^{58}$ Entrevista pessoal com Sandra Campos, da área de assuntos corporativos, responsável pelo programa Nutrir.
} 
empresa busca também desenvolver entre os envolvidos (funcionários, comunidades e fornecedores) a consciência que se deve tratar com respeito o meio ambiente.

A empresa desenvolve também convênios na área de educação, especialmente com as Universidades de Viçosa e Goiás, para o aprimoramento da produção leiteira de seus fornecedores, e com a Escola Paulista de Medicina, para o desenvolvimento das técnicas de nutrição.

Foi criado um programa de prestação de serviços aos produtores de leite (um dos principais grupos de fornecedores de matéria prima da empresa), denominado "Serviço Nestlé ao Produtor" (SNP). Este serviço visa basicamente ao contato de técnicos da empresa com os produtores, e objetiva a orientação para aquisição e instalação de equipamentos e práticas para aumento da rentabilidade da atividade leiteira.

\subsection{3 - A Estrutura Organizacional para Lidar com as Atividades de Responsabilidade Social}

No que diz respeito à estrutura organizacional, as ações de responsabilidade social estão internalizadas na empresa, em razão da elevada especificidade das ações desenvolvidas e de sua relação intrínseca com a atividade de negócios. Destacam-se, no caso da Nestlé, as condiçōes criadas organizacionalmente para a participação de funcionários voluntários que atuam nos programas sociais da empresa. A empresa consegue, por meio da participação dos voluntários, desenvolver ações que, em parte, poderiam ser realizadas por uma estrutura formal, sem precisar ter muitos funcionários especificamente para estas atividades.

\footnotetext{
${ }^{59}$ A empresa cede 8 horas mensais para as atividades voluntárias dos funcionários. Os funcionários se utilizam também de parte de suas horas livres para o trabalho nas comunidades.
} 
A empresa possui a Fundação Nestlé de Cultura, que desenvolve ações especificas na área cultural, com incentivos da lei Rouanet. Na prática, porém, a Fundação desenvolve suas atividades na própria empresa, e atua como um órgão interno dentro da estrutura organizacional da empresa. A Fundação está subordinada, na estrutura organizacional, à área de Assuntos Corporativos. Esta área coordena todos os projetos de responsabilidade social da empresa (exceto os da área de meio ambiente, que têm estrutura técnica especifica).

\subsection{4 - Evidências de retorno à imagem corporativa}

Foram salientadas em entrevistas realizadas na empresa as potencialidades de ganhos à imagem corporativa que as ações de responsabilidade social poderiam trazer para a Nestlé. Esta constatação foi a tônica que desencadeou a mudança estratégica da empresa no Brasil em 1999, delineando um programa na linha social. Para explorar sinergias com a atividade central (core) da empresa, foi criado o Programa Nutrir, com bases mais profissionais. O programa implementado no Brasil vem ganhando destaque na própria matriz, tendo sido citado no relatório mundial da Nestlé como um dos oito projetos da área social da empresa mais bem-sucedidos.

Entre os funcionários, as ações sociais têm obtido repercussão positiva. A sinergia entre as estratégias do negócio e o tipo de ação social da empresa pode explicar as evidências de sucesso do engajamento voluntário dos funcionários, e está em sintonia com as conclusōes da pesquisa de Fischer e Falconer (1999). A área de recursos humanos da empresa menciona evidências (embora não tenha quantificado) do crescente número de candidatos a vaga na empresa que procuram saber detalhes das ações sociais da Nestlé.

Na percepção dos executivos entrevistados, as ações sociais ainda não têm reflexo direto nas vendas dos produtos da empresa no Brasil. Mas existe a clara percepção do impacto decorrente das ações de responsabilidade social na 
reputação corporativa, tornando estas atividades um componente estratégico para a agregação de valor à empresa no médio prazo.

Nos anos recentes a empresa vem obtendo reconhecimento, com diversas citações:

- Citada no Guia Exame (97/98/99/2000) como uma das 100 melhores empresas para se trabalhar.

$\mathrm{Na}$ classificação da revista Exame em 2001, a pontuação segundo os critérios para escolha das 100 melhores foi a seguinte (tabela 14):

Tabela 14 - Pontuação obtida pela Nestlé para a sua inclusão entre as 100 melhores empresas para se trabalhar da revista Exame.

\begin{tabular}{l|c}
\hline Item & Pontuação \\
\hline Remuneração & $\mathbf{X X X X}$ \\
\hline Benefícios & $\mathbf{X X X}$ \\
\hline Oportunidades de carreira e treinamento & $\mathbf{X X X}$ \\
\hline Segurança e confiança na gestão & $\mathbf{X X X X}$ \\
\hline Orgulho do trabalho e da empresa & $\mathbf{X X X X}$ \\
\hline Clareza e abertura na comunicação interna & $\mathbf{X X X X}$ \\
\hline Camaradagem no ambiente de trabalho & $\mathbf{X X X}$ \\
\hline Responsabilidade social & $\mathbf{X X X X}$ \\
\hline
\end{tabular}

Fonte: Revista Exame - 100 melhores empresas para você trabalhar, 2001.

Pontuação máxima - XXXXX

Pontuação mínima $-X$

- Citada como modelo de empresa social no Guia Exame de Boa Cidadania Corporativa, em 2001. A tabela 15 apresenta a atribuição de pontuação à Nestlé. 
Tabela 15 - Atribuição de pontos à Nestlé no Guia Exame da Boa Cidadania Corporativa, 2001

\begin{tabular}{l|c}
\hline Item & Pontuação \\
\hline Valores e transparência & $\mathrm{XXXX}$ \\
\hline Funcionários e público interno & $\mathrm{XXX}$ \\
\hline Meio ambiente & $\mathrm{XXX}$ \\
\hline Fornecedores & $\mathrm{XXXX}$ \\
\hline Consumidores e Clientes & $\mathrm{XXXXX}$ \\
\hline Comunidade & $\mathrm{XXXXX}$ \\
\hline Governo e Sociedade & $\mathrm{XXXXX}$ \\
\hline
\end{tabular}

Fonte: Revista Exame - Guia de Boa Cidadania Corporativa, 2000.

Pontuação máxima $-X X X X X$

Pontuação mínima - $X$

Mundialmente, a preocupação da Nestlé com a reputação corporativa fez com que a empresa figurasse na lista das empresas mais admiradas do mundo da revista Fortune (2002), ocupando a $32^{\mathrm{a}}$ posição geral e a $1^{\mathrm{a}}$ no setor de alimentos, conforme mostra a tabela 16.

Tabela 16 - As empresas mais admiradas do mundo setor de alimentos, 2002.

\begin{tabular}{l|c}
\hline Empresa & Pontuação \\
\hline Nestlé & 6.62 \\
\hline Unilever & 5.82 \\
\hline Groupe Danone & 5.56 \\
\hline Sara Lee & 5.48 \\
\hline H.J. Heinz & 5.36 \\
\hline ConAgra & 5.32 \\
\hline Snow Brand Milk Products & 3.48 \\
\hline
\end{tabular}

Fonte: Revista Fortune, 2002. 
Na pesquisa da revista Fortune, os itens considerados são: qualidade da administração, talento dos funcionários, capacidade financeira, qualidade de produtos e serviços, capacidade de inovação, uso dos ativos corporativos, grau de globalização e responsabilidade social. 


\section{3 - CASO 3 - SADIA}

\subsection{1. - Informações básicas}

A Sadia foi fundada em 1944, na cidade de Concórdia em Santa Catarina. Iniciou as suas atividades com um pequeno moinho de trigo, um abatedouro e poucos funcionários, e hoje é uma das principais empresas nacionais. Possui aproximadamente 29 mil funcionários, 12 unidades industriais, 19 filiais comerciais no Brasil e representações em vários países. No mercado interno a produção chega a cerca de 90 mil pontos de venda, com exportações para 60 paises.

É a empresa líder em alimentos congelados e resfriados no Brasil, de acordo com a AC Nielsen (Sadia -Relatório Anual, 2000). A linha de produtos da empresa vem se diversificando ao longo dos últimos anos em produtos industrializados/processados, aves e suínos. No ano 2000 as vendas totais da Sadia atingiram 1,16 milhões de toneladas ( $R \$ 3,25$ bilhões), dos quais as exportações representaram cerca de $27 \%$ do total.

A empresa se destaca pela produção de alimentos derivados de carnes suina, bovina, de frango e de peru, e tem incrementado cada vez mais a fabricação e distribuição de alimentos industrializados prontos e semiprontos, especialmente congelados e resfriados, também de outras matérias primas. A Sadia é a primeira empresa do mercado brasileiro em volume de vendas no ranking dos segmentos de alimentos congelados, resfriados, carnes de frango, peru e suínos, e a terceira no mercado de margarinas. A Sadia tem procurado aumentar expressivamente sua presença no mercado internacional. No ano 2000 as exportações representaram $26,8 \%$ da receita bruta da empresa, $4 \%$ a mais do que no ano 1999.

$\mathrm{Na}$ composição da receita da empresa, os produtos industrializados representam $50 \%$ do faturamento, as carnes in natura de frango $29 \%$, peru $7 \%$, 
suíno $6 \%$, e outros produtos $8 \%$. A tabela 17 apresenta o volume de vendas da empresa nos mercados interno e externo em 1999 e 2000.

Tabela 17 - Receita da Sadia em 1999 e 2000 (R\$ milhões)

\begin{tabular}{l|c|c}
\hline Venda valor & 1999 & 2000 \\
\hline Mercado Interno & 2306,3 & 2384,6 \\
\hline Mercado Externo & 839,7 & 873,4 \\
\hline Total & 3146,0 & 3257,9 \\
\hline
\end{tabular}

Fonte: Sadia -Relatório anual, 2001.

No ano 2000 a Sadia registrou um lucro líquido de $\mathrm{R} \$ 112,3$ milhões, que representou um retorno sobre o patrimônio líquido (ROE) de $11,8 \%$, enquanto em 1999 o lucro foi de $\mathrm{R} \$ 73$ milhões, com um ROE de 8,5\%. O capital social da empresa é representado por 683 milhões de títulos: 257 milhões de ações ordinárias e 426 milhões de ações preferenciais, e um total de 8.400 acionistas.

\subsection{2 - As atividades de Responsabilidade Social da Sadia}

A posição estratégica da Sadia com relação às atividades de responsabilidade tem duas motivações distintas: a "necessidade" e a "opção"60.

Basicamente, a empresa segue a linha da necessidade, desenvolvendo ações de redução de impactos ambientais nas regiões onde opera, inerentes ao próprio sistema de produção de aves e suínos, que são altamente susceptíveis a riscos ambientais. Outro fator é a crescente estratégia de internacionalização da empresa, especialmente nos mercados da Ásia, Oriente Médio e Europa. A pressão dos mercados externos tem se tornado cada vez maior, tanto no que se refere aos aspectos intrínsecos da qualidade dos produtos, como no que diz respeito à preocupação com a rastreabilidade de todo o processo produtivo,

\footnotetext{
${ }^{60}$ Conforme relato em entrevista pessoal com o Sr. José Femando Monteiro Alves, consultor da presidência do conselho de Administração da Sadia.
} 
incluindo as relações sociais com fornecedores, processos de abate e práticas ambientais.

A outra linha de ação social que a empresa segue como opção é a educação/cultura do público interno (funcionários e familiares) e de membros das comunidades ligadas à empresa.

De acordo com documento elaborado pela empresa (Sadia - Relatório Social 2000), as principais ações de responsabilidade social desenvolvidas pela Sadia são:

\section{1) Programas ligados ao Meio Ambiente:}

a) Programas de Reciclagem entre os produtores integrados - Consistem em programas de reciclagem de material orgânico utilizado nas lavouras dos produtores integrados e de materiais inorgânicos revendidos a indústrias de reciclagem.

b) Programas de Recuperação e Proteção Ambiental - A empresa implementa as normas estabelecidas pelo Banco Mundial no tratamento de resíduos e efluentes, e na preservação de rios e lagos próximos às unidades industriais. A empresa busca também desenvolver metas de redução de consumo de água, lenha e energia elétrica.

c) Conscientização Ambiental - A empresa desenvolve programas com metas de qualidade e cuidado ambiental nas granjas dos cerca de dez mil produtores integrados de aves e suinos.

\section{2) Programas Ligados à Educação}


a) Educação Adulta - este programa consiste na complementação educacional de empregados que não possuem o ensino fundamental completo. A partir da implementação do programa, o número de funcionários com ensino básico completo passou de $74 \%$ para $95 \%$.

b) Alfabetização Solidária - Para implementar o programa de alfabetização solidária a empresa adotou, como área de atuação, o município de Caracol (PI), colaborando com o ensino de 1.750 pessoas.

c) Canal Futura - É o primeiro canal brasileiro de televisão educativa gerido e financiado pela iniciativa privada, com programação voltada para $\circ$ desenvolvimento educacional e profissionalizante. A Sadia é uma das empresas patrocinadoras do canal Futura, e vem contribuindo desde $1997 \mathrm{com}$ cerca de $R \$ 1,1$ milhões anuais.

\section{2) Outras ações de Responsabilidade Social}

Além dos principais programas e projetos ligados à questões ambientais e educacionais, a Sadia desenvolve outras ações pontuais, como incentivo ao esporte, doação de alimentos às comunidades, programas de informática, projetos culturais e auxilio a pesquisas médicas.

\subsection{3 - A Estrutura Organizacional para Lidar com as Atividades de Responsabilidade Social}

A Sadia instituiu a Fundação Attílio Fontana, mas com escopo de atuação limitado, funcionando como uma entidade de previdência privada e assistência social. Aos participantes da Fundação são oferecidas aposentadorias e pensões, suplementação de auxílio-doença e empréstimos. Desenvolve ainda algumas atividades de promoção social voltadas especialmente para os funcionários da empresa, nas diversas comunidades onde a empresa opera. 
A Sadia não possui um orçamento básico para tais atividades, como a destinação de porcentagem de lucro ou faturamento. Os projetos sociais são discutidos caso a caso. Mas em virtude do crescimento das ações de responsabilidade social a empresa estuda um modelo mais formalizado e centralizado para a definição estratégica das ações sociais que a empresa deverá implementar.

Cogita-se na empresa a possibilidade de centralização das sua atividades de cunho social, para ter um maior controle estratégico e monitoramento das atividades, seja pela Fundação ou por meio da criação de uma estrutura formal no próprio organograma da empresa. Em princípio, a própria Fundação Attilio Fontana poderia ser reestruturada para esta finalidade, mantendo as funções básicas fora da estrutura central da empresa, mas mantendo-se a orientação estratégica por parte desta. A opção atual é o modelo A (operacionalização direta das ações sociais), embora a empresa já cogite a possibilidade de adotar a opção B (fundação própria).

\subsection{4 - Evidências de retorno à imagem corporativa}

A Sadia foi uma das empresas selecionadas para compor o Fundo Ethical do ABN AMRO BANK. Conforme mencionado em capítulo anterior, o Fundo Ethical é composto de ações de empresas que passam pelo crivo de uma comissão que analisa a conduta ética das empresas.

A exemplo da Nestlé, a Sadia também tem produtos direcionados para o consumo final e, também na percepção dos executivos entrevistados, as ações sociais ainda não têm reflexo direto nas vendas dos produtos da empresa no Brasil. 
Mas os executivos têm a percepção do potencial impacto das ações de responsabilidade social na reputação corporativa, especialmente pelo fato de a empresa ter uma estratégia cada vez mais agressiva nos mercados externos, notadamente na Europa.

O outro aspecto da preocupação em desenvolver açōes de responsabilidade social é decorrente dos potenciais danos ambientais e sociais, inerentes à própria atividade produtiva, que a empresa possa causar às comunidades circunvizinhas das fábricas. Tal preocupação se estende aos fornecedores de aves e suínos integrados. Neste sentido, as ações sociais da empresa para o seu conjunto de stakeholders têm um forte componente de minimizador dos riscos de perda de reputação. 


\section{4 - CASO 4 - PERDIGÃO}

\subsection{1. - Informaçōes básicas}

Duas famílias de imigrantes italianos (Ponzoni e Brandalise) iniciaram as atividades da Perdigão em 1934, com um pequeno negócio de secos e molhados em Vila das Perdizes/SC, atual município de Videira. Em 1939 as famílias iniciaram-se nas atividades agroindustriais, com um pequeno abatedouro de suínos. A partir de então, a empresa seguiu uma expressiva trajetória de crescimento. Atualmente a empresa emprega cerca de 20 mil funcionários, em 13 unidades industriais de carne, 02 unidades de soja, 07 fábricas de ração, 14 incubatórios e 21 centros de distribuição (Relatório Anual Perdigão, 2001).

A base da linha de produtos da Perdigão a exemplo da Sadia, tem como matéria-prima as carnes de aves e suínos. A empresa tem seguido uma linha acentuada de diversificação nos últimos anos, comercializando, além dos produtos in natura, uma linha com cerca de 400 itens de produtos de maior valor adicionado, restriados e congelados. Além disto, o foco crescente da empresa é a busca de crescimento no mercado internacional. A tabela 18 apresenta a evolução do faturamento bruto da empresa entre 1994 e 2000, destacando o expressivo crescimento no período, tanto no mercado interno como no externo.

Tabela 18 - Evolução do faturamento bruto da Perdigão no período 1994-2000 (R\$ milhōes)

\begin{tabular}{l|l|l|l|l|l|l|l}
\hline & 1994 & 1995 & 1996 & 1997 & 1998 & 1999 & 2000 \\
\hline Mercado Interno & 354 & 667 & 773 & 938 & 1108 & 1284 & 1554 \\
\hline Mercado externo & 116 & 180 & 244 & 330 & 307 & 517 & 512 \\
\hline Total & 470 & 847 & 1017 & 1268 & 1415 & 1801 & 2066 \\
\hline
\end{tabular}

Fonte: Relatório Anual Perdigão 2001.

A partir de 1994, o controle acionário da empresa foi adquirido por um pool de fundos de pensão, desencadeando a implantação de uma gestão 
profissionalizada, com profunda reestruturação organizacional e reposicionamento estratégico. A composição acionária da empresa, quanto à porcentagem do capital social, segundo dados de 30/06/01, está distribuída conforme mostra a tabela 19:

Tabela 19 - Composição acionária da Perdigão

\begin{tabular}{l|c}
\hline Acionista & Capital Social (\%) \\
\hline Previ - Banco do Brasil & 18,52 \\
\hline Petros - Petrobrás & 14,58 \\
\hline Sistel - Telebrás & 17,92 \\
\hline Fapes - BNDES & 12,17 \\
\hline WEG S/A & 10,13 \\
\hline Vale do Rio Doce & 1,96 \\
\hline Real Grandeza APAS & 10,21 \\
\hline Telos - Embratel & 1,07 \\
\hline Previ - Banerj & 3,33 \\
\hline Outros & 10,12 \\
\hline
\end{tabular}

Fonte: Perdigão - Relatório Investindo no ser Humano - 2000/2001.

A partir de 2000 a Perdigão lançou os American Depositary Receipts (ADR'S), na Bolsa de Nova lorque. Foi a primeira empresa do setor de alimentos no Brasil a negociar ADR's na bolsa de Nova lorque. Para se adequar ao novo mercado acionário a empresa consolidou mudanças no aspecto de governança corporativa, aumentando a transparência das informações. $O$ conselho de administração é composto de sete membros e seu presidente não faz parte do atual acordo de acionistas controladores. Todos os membros têm atividades externas, reunindo-se mensalmente. As assembléias dos acionistas são realizadas com presença média acima de $90 \%$ dos representantes do capital votante e de $70 \%$ dos representantes do capital total. O conselho fiscal é composto de três membros entre os acionistas controladores e um entre 
minoritários. Além do relatório anual, os acionistas e o mercado recebem informações trimestrais com dados da performance da empresa.

No período de 1994 a 2000 a empresa passou a apresentar uma evolução nos resultados líquidos e na remuneração dos acionistas. $O$ volume de investimentos foi expressivo, representando um investimento médio de cerca de $R \$ 130$ milhões anuais. A tabela 20 ilustra a evolução no período.

Tabela 20 - Evolução do resultado líquido, investimentos e remuneração do acionista da Perdigão no período de 1994 a 2000 (R\$ milhões)

\begin{tabular}{l|l|l|l|l|l|l|l}
\hline & 1994 & 1995 & 1996 & 1997 & 1998 & 1999 & 2000 \\
\hline Resultado Líquido & 12 & 31 & 10 & 43 & 60 & 47 & 45 \\
\hline Remuneração ao acionista & - & 9 & 5 & 12 & 16 & 13 & 14 \\
\hline Investimentos & 8 & 55 & 124 & 81 & 133 & 190 & 216 \\
\hline
\end{tabular}

Fonte: Relatório Anual Perdigão 2001.

\subsection{2 - As atividades de Responsabilidade Social da Perdigão}

A Perdigão optou nos anos recentes pela modernização do seu modelo de gestão, a partir da reorganização societária em 1994, buscando, com a profissionalização da gestão, aproximar-se dos princípios de governança corporativa.

Com base na da nova orientação estratégica, a responsabilidade social passou a ser uma das diretrizes corporativas da empresa, de acordo com a visão do conselho de administração e da alta gestão de que o conceito de empresa socialmente responsável deveria ser perseguido pela empresa, como forma de alavancar a sua imagem corporativa.

A percepção da alta gestão devida ao fato de que a empresa atua em um ramo de atividade altamente susceptivel a riscos e tensões ambientais e sociais. $A$ 
atividade de produção de aves e suínos é altamente poluidora, com seus dejetos, e as relações da empresa com seus fornecedores de aves e suínos para abates (produtores integrados) é extremamente crítica para o negócio da empresa.

Assim como no caso da Sadia, a Perdigão também tem perseguido a estratégia da internacionalização, e conseqüentemente sofre a pressão dos mercados externos, para que se considerem os aspectos intrínsecos da qualidade dos produtos, a rastreabilidade de todo o processo de produtivo, as relações sociais com fornecedores, os processos de abate e as práticas ambientais.

Conforme destacado em relatório da empresa (Perdigão Hoje, 2000, p.6):

De outro lado, a nova postura da empresa também passou a ser ditada, em grande parte pelo mercado. Fatores como qualidade, preço competitivo e bom atendimento continuam fundamentais, mas estão deixando de ser diferenciais ou, pelo menos, de fazer toda a diferença na escolha do produto. É preciso criar uma ponte entre marca e o consumidor, através de uma afinidade de valores. E essa ponte é a responsabilidade social, uma ferramenta de marketing que está se tornando indispensável para toda empresa.

O foco das ações de responsabilidade social da empresa é o seu público interno $e$ as comunidades em torno de suas fábricas. Basicamente, a empresa orienta suas ações de responsabilidade social para três vertentes:

a) ao público interno:

O principal foco das atividades de responsabilidade social que se dirigem ao público interno é a questão educacional, e está integrado à política de recursos humanos. A empresa lançou um programa em 1995, cuja intenção era que nenhum funcionário ficasse sem o primeiro grau completo. Neste processo, a 
empresa obteve êxitos que em grande parte são atribuídos a este programa, com ganhos de produtividade e assimilação mais veloz ao processo tecnológico.

Todos os funcionários são incluídos em um programa de participação nos lucros, e contemplados com plano de saúde e creches para crianças. Os funcionários casados que estão na empresa por mais de cinco anos são beneficiados por um programa de construção de casa própria subsidiado pela empresa, que já possibilitou a construção de 390 residências até 2001.

b) ao conjunto de produtores de aves e suinos integrados:

Os projetos sociais para cerca de 6.290 produtores integrados de aves e suínos tem como foco a busca de agregação de valor às pequenas propriedades, por meio de programas de renda acessórios, como produção de milho, piscicultura com aproveitamento de dejetos de aves e suínos, entre outros fomentados pela empresa.

Em todos os programas de suporte aos produtores a empresa procura promover a implementação de práticas ambientais preventivas, como forma de redução de riscos ambientais. Existem aproximadamente 6.290 produtores integrados de aves e suínos, empregando cerca de 21.000 pessoas. Os funcionários da empresa são orientados a dar suporte técnico, desenvolver campanhas de esclarecimento e fiscalização da mão-de-obra infantil.

c) à comunidade onde a empresa possui plantas industriais:

A maior iniciativa social da Perdigão na comunidade tem se dado em Rio Verde, onde a empresa está instalando uma unidade industrial de grande porte. Em parceria com o BNDES, vem sendo implantado um programa para uma melhor qualidade de vida da população, denominado "Atende". A empresa investe $R \$ 1,1$ milhão no projeto, e o BNDES investe igual valor por meio de redução de taxas de 
juros para o financiamento da implantação do projeto agroindustrial da empresa em Rio Verde. O programa "Atende" é um conjunto de nove postos de saúde integrados a postos de segurança em bairros carentes da cidade, com cerca de 900 atendimentos médicos diariamente. $\mathrm{Na}$ área de educação, o programa prevê a construção de seis creches para atendimento de filhos de funcionários e de crianças da comunidade, além de projetos para proteção ao meio ambiente.

A Perdigão possui técnicos responsáveis por garantir que os dejetos industriais gerados pelas plantas industriais e os efluentes sejam tratados de acordo com a legislação vigente, embora ainda não tenha implementado um amplo programa de gestão ambiental. A empresa está desenvolvendo um projetopiloto para implementar um sistema de gestão ambiental, visando a obtenção da ISO 14001.

Entre as atividades de desenvolvimento e preservação ambiental relacionadas no relatório interno (Perdigão - investindo no ser humano 2000/2001), há o apoio à manutenção da reserva ecológica Vida Verde, próxima a planta de Maraú, no estado do Rio Grande do Sul, e a manutenção da llha Fluvial Hermínio Salata de Almeida, em Videira/SC, em parceria com a Universidade do Oeste de Santa Catarina (UNOESC) e a prefeitura Municipal de Videira. Como parte do investimento na construção da planta de Rio Verde, mantém o Parque Ecológico do Córrego Barrinha, próximo à cidade.

A empresa não publica relatórios ambientais. Entretanto, o departamento de relações com investidores e os engenheiros ambientais se dispõem a fornecer informações requisitadas sobre estas questões ${ }^{61}$.

\footnotetext{
${ }^{61}$ Conforme relato em entrevista pessoal com Christhoper Wells, analista de SRI (Social Report Investing Company Profile), responsável pelo relatório da Perdigão elaborado em Janeiro de 2001.
} 


\subsection{3 - A Estrutura Organizacional para lidar com as atividades de Responsabilidade Social}

As ações de responsabilidade social da empresa, embora distribuídas por toda a corporação, têm a sua orientação estratégica centralizada na diretoria de Relações Institucionais.

A empresa não possui um orçamento básico para tais atividades, como a destinação de porcentagem de lucro ou faturamento. Entretanto, conforme relato do diretor da área ${ }^{62}$, com o aumento da escala das atividades sociais a empresa pretende caminhar para um modelo mais formalizado. Cogita-se também a criação de uma Fundação própria para a centralização destas atividades, cujas funções básicas ficariam fora da estrutura central da empresa, que, entretanto, manteria a orientação estratégica sob seu domínio.

Embora a empresa mantenha parcerias, especialmente com prefeituras das cidades em que possui operação industrial e com o BNDES, não se cogita, por exemplo, a destinação de recursos para uma outra entidade especializada em atividades de responsabilidade social, especialmente de caráter filantrópico. A justificativa dada é que a atuação social da empresa está intrinsecamente ligada às suas atividades de negócios, com alta especificidade, e portanto a opção $\underline{\mathrm{C}}$ proposta no modelo teórico (parcerias sem operacionalização das atividades sociais) não seria a mais eficiente. A opção atual é o modelo $A$ (operacionalização direta das ações sociais), embora a empresa já cogite a possibilidade de adotar a opção B (fundação própria).

\subsection{4 - Evidências de retorno à imagem corporativa}

Alguns fatos ilustram o reconhecimento às ações de responsabilidade social da empresa (RelatórioAnual Perdigão, 2001):

\footnotetext{
${ }^{62}$ Entrevista pessoal realizada com o Sr. Ricardo Menezes, Diretor de Relaçōes Institucionais da Perdigão.
} 
- A Perdigão é incluida no Guia Exame de Boa Cidadania Corporativa 2000, como exemplo de empresa socialmente responsável.

A empresa conseguiu classificações significativas nos itens da pesquisa da revista, conforme a tabela 21 :

Tabela 21 - Atribuição de pontos para a Perdigão no Guia Exame da Boa Cidadania Corporativa, 2000

\begin{tabular}{l|c}
\hline Item & Pontuação \\
\hline Valores e transparência & $\mathbf{X X X X}$ \\
\hline Funcionários e público interno & $\mathrm{XX}$ \\
\hline Meio ambiente & $\mathrm{XXXX}$ \\
\hline Fornecedores & $\mathrm{XXX}$ \\
\hline Consumidores e Clientes & $\mathrm{XXXXX}$ \\
\hline Comunidade & $\mathrm{XXXX}$ \\
\hline Governo e Sociedade & $\mathrm{XXXX}$ \\
\hline
\end{tabular}

Fonte: Revista Exame - Guia de Boa Cidadania Corporativa, 2000.

Pontuação máxima $-X X X X X$

Pontuação mínima - $X$

- Em 1995 a Perdigão recebeu o Prêmio Expressão de Ecologia, da Revista Expressão, como empresa de destaque na proteção ao meio ambiente.

- Em 1996 a empresa recebeu o Prêmio ABAMEC, da Associação Brasileira de Analistas de Mercado de Capitais.

- Em 1996 a empresa recebe o Prêmio Sesi Santa Catarina de Qualidade de Vida no Trabalho.

- Em 1995 a empresa recebeu o Prêmio Mauá, da Bolsa de Valores do Estado do Rio de Janeiro, pela qualidade e transparência de suas informações ao mercado de capitais. 
- A Perdigão foi incluída em 1999 e 2000 na lista das 100 melhores empresas para se trabalhar no Brasil.

- Em 1996 e 2000 a empresa recebeu o Prêmio Fritz Muller, do órgão ambiental FATMA de Santa Catarina, pela gestão ambiental na unidade industrial de Capinzal/SC.

\section{5 - ANÁLISE COMPARATIVA dOS CASOS À LUZ DO REFERENCIAL TEÓRICO}

Algumas análises podem ser feitas a partir dos quatro casos descritos. Podem ser definidos três blocos, de acordo com as similaridades encontradas:

- Sadia e Perdigão;

- Nestlé;

- Grupo Orsa (Orsa Celulose, Papel e Embalagens e Jari Celulose)

\subsection{1 - Sadia e Perdigão}

Um aspecto de destaque é a similaridade entre a Sadia e a Perdigão. Ambas são do mesmo ramo de atividade, concorrentes diretas e com tamanho similar. A estratégia de negócio de ambas também apresenta muita semelhança, no mix de produtos, no aumento de produtos processados resfriados e congelados e na crescente presença no mercado externo. Da mesma forma, ambas desenvolvem um sistema contratual com produtores de suínos e aves, visando ao suprimento das matérias-primas básicas (aves e suínos em ponto de abate).

Não é de estranhar, portanto, a similaridade das ações de responsabilidade social das duas empresas. As pressões contra o impacto ambiental gerado pela atividade destas empresas são crescentes, tanto do mercado consumidor (especialmente compradores do mercado externo), instituições financeiras (Banco 
Mundial, BNDES) como das normas regulatórias crescentemente restritivas impostas pelo Estado.

A outra principal linha de atuação social das empresas é a educacional, que tem como motivador central as demandas internas das próprias empresas, e pode ser considerada uma extensão das suas políticas de recursos humanos, embora gerando também externalidades positivas às comunidades.

Parece claro que a motivação central, com base no modelo de Fombrun (2000), paras as ações de responsabilidade social das duas empresas, especialmente no aspecto ambiental é a minimização de riscos, para evitar perdas de reputação por eventuais acidentes causados. Este fato é corroborado pelos entrevistados, os quais destacam que esta tendência tende a se acentuar à medida que as empresas ampliam o seu posicionamento nos mercados internacionais.

Ambas desenvolvem as ações de redução de impacto ambiental, seguindo os marcos regulatórios, não por altruismo ou eventuais acordos cooperativos, mas atendendo às mudanças impostas pelo ambiente institucional.

Quanto à estrutura organizacional para lidar com as ações de responsabilidade social, ambas as empresas internalizam estas ações, em razão de sua elevada especificidade e a relação intrínseca com a atividade de negócios. Entretanto, as empresas, conforme relatos em entrevistas, mencionaram possiveis ineficiências organizacionais, tanto na execução de ações de cunho social dentro da estrutura organizacional dos negócios, como na alocação dos recursos (ausência de uma centralização estratégica maior das ações, especialmente no caso da Sadia). Ambas cogitam centralizar as ações sociais numa Fundação que lide com as atividades de responsabilidade social, dada a escala que estas atividades já atingiram nas empresas. Porém, este tipo de discussão ainda é muito embrionário nas empresas. 
Sadia e Perdigão, igualmente, não têm um sistema que contabilize os possiveis retornos das atividades sociais desenvolvidas e a geração de valor para a empresa. Entretanto, ambas reportam ganhos de imagem corporativa com estas ações. O problema de agência nestas empresas parece não existir, pois a definição estratégica para que elas intensifiquem as ações de responsabilidade social parte do próprio conselho dos acionistas (principal), e é apenas implementada pelos gestores (agentes). O principal problema é definir uma estrutura organizacional que possibilite um sistema de monitoramento eficiente das ações de responsabilidade social.

Em síntese, ambos os casos são motivados pela visão socioeconômica modelo de Quazi e O'Brien (2000) das ações de responsabilidade social. Neste sentido, a visão dos stockholders e dos stakeholders concordam em que as ações de responsabilidade social destas empresas visam a maximizar o valor dos acionistas, a partir de uma estratégia que leva em conta os interesses dos demais stakeholders.

\subsection{2 - Nestlé}

A preocupação da Netlé com os aspectos de responsabilidade social decorre, em essência, da alta exposição e visibilidade internacional da empresa. Existem princípios básicos de conduta definidos no âmbito da matriz que devem ser seguidos por todas as suas filiais no mundo todo.

A partir da orientação global, as filiais no mundo se adequam aos respectivos ambientes institucionais para a definição de projetos específicos no âmbito da responsabilidade social. No Brasil, a empresa segue os princípios básicos da matriz, nas questões de meio ambiente, relações trabalhistas, relações com fornecedores e clientes, e o foco é o cumprimento das normas e padrões legais vigentes, seguindo tanto a legislação do país quanto as normas específicas de 
organismos internacionais, como a Organização Internacional do Trabalho (OIT) e a Organização Mundial de Saúde (OMS).

Especificamente em relação às ações sociais, estas passaram a ser parte de uma preocupação estratégica da empresa a partir de 1999. As ações pontuais e descentralizadas realizadas anteriormente passaram a ter um componente estratégico para a organização.

Por determinação do conselho da empresa, tornou-se importante para a Nestlé desenvolver no Brasil uma linha de ação social articulada com a atividade de negócios, para agregar valor à sua imagem corporativa. Assim surgiu o programa Nutrir, que passou a ser a forma de expressão mais visivel das ações de responsabilidade social da empresa, tanto para o público externo como para o público interno de funcionários.

A Nestlé é essêncialmente motivada pela visão socioeconômica das ações de responsabilidade social segundo o modelo de Quazi (1997). A preocupação expressa formalmente em documentos da empresa, em relação ao seu relacionamento com seus stakeholders é de que estas ações visem maximizar o valor dos acionistas, a partir de uma estratégia que leve em conta os interesses dos demais stakeholders, assim como nos casos da Perdigão e da Sadia.

Na Nestlé não se cogita a criação de uma fundação "independente" para atuar em projetos sociais. A justificativa é de que os projetos sociais da Nestlé estão intrinsecamente relacionados com a atividade de negócios da empresa (alta especificidade), e de que a empresa conta com um grupo de voluntários que possui grande expertise nas questões ligadas à nutrição, centro das açōes de responsabilidade social da empresa. Embora já exista a Fundação Nestlé de Cultura, na prática a sua atuação está inserida na estrutura organizacional da empresa. 
4.5.3 - Grupo Orsa (Orsa Celulose, Papel e Embalagens e Jari Celulose)

As atividades de responsabilidade social do grupo Orsa têm uma gênese distinta da das demais empresas, sob dois aspectos básicos:

1) $O$ enfoque da responsabilidade social independente da atividade de negócios do grupo;

2) O tipo de estrutura organizacional para o desenvolvimento das ações de responsabilidade social:

1 - O principal foco da responsabilidade social do Grupo Orsa são as ações da Fundação Orsa, que, embora dependente financeiramente do Grupo, tem suas atividades definidas e implementadas com elevada autonomia em relação à estratégia empresarial do Grupo. Na definição de Quazi (1997), a empresa poderia estar classificada no eixo de reponsabilidade ampliada (nos quadrantes da visão filantrópica ou moderna). Ou seja, o fator motivacional indutor das ações sociais não foi condicionado aos fatores de racionalidade econômica, como aparece mais evidenciado nas demais empresas, embora nenhuma evidência exista de que a empresa não esteja agregando valor por meio das ações de responsabilidade social. Tampouco se pode afirmar o contrário.

Mesmo que inexista a criação de valor para os acionistas, o caso do grupo Orsa não se configura um potencial problema de agência, pois a decisão do investimento em ações sociais parte do proprio acionista. Pode-se especular, neste sentido, que a função-objetivo do acionista não seria necessariamente apenas maximizar o seu retorno econômico, mas também derivar utilidade utilidade das ações sociais (em consonância com a visão de Sen, 1999).

Entretanto, na pespectiva de o Grupo Orsa vir a abrir o capital, ou mesmo buscar parcerias por meio de fusões ou alianças, os recursos canalisados para 
ações sociais podem ou não se tornar entraves, dependendo da reação dos potenciais sócios ou acionistas. $\mathrm{O}$ atual controlador e acionista majoritário não coloca em discussão o compromisso do Grupo com a dotação orçamentária da Fundação Orsa, e este é um pré-requisito básico a ser adotado nos eventuais processos de negociação ${ }^{63}$.

2 - A ação social do Grupo Orsa por intermédio da Fundação Orsa (especialmente no exemplo da empresa Jari Celulose) mostrou ser um modelo mais eficiente de gestão, porque há uma maior distinção do papel dos gestores da empresa (que estariam focados na atividade do negócio específico) e as atividades dos gestores da Fundação (focados nas ações de cunho eminentemente social). Entretanto, se tal modelo, por um lado, apresenta maior eficiência organizacional e menores custos de agência, por outro a empresa ainda não explora de forma plena as oportunidades de maior agregação de valor ao seu negócio, com sinergias que poderiam potencializar a imagem corporativa. Os acionistas e a alta gestão do grupo Orsa parecem ter a percepção de tal fato, e buscam implementar um novo projeto de integração estratégica entre as empresas do grupo e a Fundação Orsa, visando a explorar de forma mais intensa as potenciais sinergias entre as estruturas empresariais e sociais do grupo.

\section{6 - RELAÇÃo entre os estudos de caso e AS hIPóteses de PESQUISA PROPOSTAS}

Ao se estabelecer relações entre as hipóteses apresentadas no trabalho a respeito da motivação das empresas para atividades de responsabilidade social, os casos analisados se enquadraram da seguinte forma:

A hipótese central é de que o principal incentivo que leva as empresas a se engajarem em atividades de responsabilidade social é a percepção de que este

${ }^{63}$ Conforme relato pessoal do acionista majoritário do Grupo Orsa, Sérgio Garcia Amoroso. 
tipo de conduta leva ao aumento do capital reputacional e do valor da empresa no longo prazo:

As empresas Nestlé, Sadia e Perdigão evidenciaram esta hipótese. A motivação central destas empresas para as práticas de responsabilidade social tem um claro aspecto instrumental. A percepção dos acionistas e executivos destas empresas é de que estas ações são estrategicamente importantes para a construção do capital reputacional e do valor da empresa.

As ações de responsabilidade social implementadas pelo Grupo Orsa são devidas a outra motivação, relacionada principalmente com razões pessoais do principal acionista e controlador do Grupo.

Outras hipóteses decorrentes:

\section{Hipótese A}

Empresas exportadoras de produtos agroalimentares que atuam em mercados consumidores crescentemente exigentes tendem a ampliar o escopo da responsabilidade social para além das responsabilidades econômicas e legais, procurando desenvolver ações sociais/ambientais mais amplas entre as comunidades onde possuem bases produtivas.

- Os estudos de caso das empresas Sadia e Perdigão foram os que apresentaram maiores evidências em relação a esta hipótese.

\section{Hipótese B}

Empresas envolvidas em atividades potencialmente sujeitas a riscos de naturezas diversas desenvolvem ações de responsabilidade social além das 
ações de responsabilidade econômica/legal, em virtude de potenciais problemas ambientais e/ou sociais causados às comunidades;

- Os estudos de caso das empresas Sadia, Perdigão e Jari (Grupo Orsa) foram os que apresentaram maiores evidências em relação a esta hipótese.

\section{Hipótese C}

Empresas que buscam alavancar recursos no mercado de capitais desenvolvem ações de responsabilidade social além das ações de responsabilidade econômica/legal;

- Os estudos de caso das empresas Sadia e Perdigão foram os que apresentaram maiores evidências em relação a esta hipótese.

\section{Hipótese D}

Empresas multinacionais desenvolvem atividades de responsabilidade social nos diversos países onde operam crescentemente seguindo orientação estratégica da matriz.

- O estudo de caso da empresa Nestlé apresentou evidências em relação a esta hipótese.

\section{Hipótese E}

A operacionalização direta de projetos sociais pela própria estrutura organizacional da empresa ocorre quando existe elevado grau de especificidade entre a atividade de negócios e as ações de responsabilidade social a serem implementadas. 
- Os estudos de caso da Nestlé, Perdigão e Sadia apresentaram evidências em relação a esta hipótese.

\section{Hipótese F}

A criação de uma estrutura "fora da firma", especializada em atividades sociais, reduz os custos de agência decorrentes do desalinhamento de interesses entre o principal (acionista/sócio) e os agentes (executivos/gestores), no caso de empresas em que exista a separação de propriedade e controle.

- O estudo de caso da Jari Celulose apresentou evidências em relação a esta hipótese.

\section{7 - CLASSIFICAÇÃo DAS EMPRESAS COM BASE NOS MODELOS} APRESENTADOS

\subsection{1 - O Modelo de Fombrun (2000)}

Com base no modelo proposto por Fombrun (geração de oportunidades e minimização de riscos), pode-se fazer uma associação qualitativa entre as motivações das empresas analisadas para o desenvolvimento das ações sociais e os seus principais stakeholders.

As tabelas 22 a 29 estabelecem as relações, na percepção do autor, de acordo com a seguinte classificação:

\footnotetext{
*** alta relevância para a empresa

** média relevância para a empresa

* baixa relevância para a empresa
} 
Tabela 22 - Relação entre as empresas analisadas e os impactos decorrentes das ações de responsabilidade social (comunidade)

\begin{tabular}{|c|c|c|}
\hline $\begin{array}{l}\text { STAKEHOLDER: } \\
\text { COMUNIDADE }\end{array}$ & $\begin{array}{l}\text { OPORTUNIDADES } \\
\text { Criação de legitimidade }\end{array}$ & $\begin{array}{l}\text { MINIMIZAÇĀO DE } \\
\text { RISCOS } \\
\text { Minimizar riscos de má } \\
\text { aceitaçāo/conflitos }\end{array}$ \\
\hline SADIA & $x x x$ & $x x x$ \\
\hline PERDIGÃO & $x x x$ & $x x x$ \\
\hline NESTLÉ & $x x$ & $x x$ \\
\hline JARI & $x x x$ & $x x x$ \\
\hline ORSA & $x x$ & $x x$ \\
\hline
\end{tabular}

Fonte: $\mathrm{O}$ autor.

\section{Comentários:}

As empresas Perdigão e Sadia, pelo tipo de atividade, são suscepítveis a altos riscos ambientais e sociais, tanto na fase de produção rural de seus produtores integrados quanto na fase industrial. As ações de responsabilidade social são uma forma de atenuar os riscos e criar legitimidade nas comunidades onde desenvolvem suas atividades. A Jari, também pelos potenciais riscos ambientais e pelo grau de dependência da comunidade circunvizinha se enquadra na mesma situação. Para a Nestlé e Orsa, embora relevante, o risco é menor em relação às demais. 
Tabela 23 - Relação entre as empresas analisadas e os impactos decorrentes das ações de responsabilidade social (Mídia)

\begin{tabular}{|c|c|c|}
\hline $\begin{array}{l}\text { STAKEHOLDER: } \\
\text { MÍDIA }\end{array}$ & $\begin{array}{l}\text { OPORTUNIDADES } \\
\text { Cobertura Favorável }\end{array}$ & $\begin{array}{c}\text { MINIMIZAÇAO DE } \\
\text { RISCOS } \\
\text { Minimizar riscos de cobertura } \\
\text { desfavorável }\end{array}$ \\
\hline SADIA & $x X X$ & $x x x$ \\
\hline PERDIGĀO & $x \times x$ & $x x x$ \\
\hline NESTLÉ & $x x x$ & $x X X$ \\
\hline JARI & $x x x$ & $x X X$ \\
\hline ORSA & $x x$ & $x x$ \\
\hline
\end{tabular}

Fonte: 0 autor.

\section{Comentários:}

A Sadia, a Nestlé e a Perdigão, necessitam criar condições para cobertura favorável, minimizando também os riscos de cobertura negativa que possam causar danos reputacionais, em função do alto grau de exposição destas empresas na mídia. $\mathrm{O}$ mesmo vale para a Jari, em função da localização em região sensível (Amazônia), e pelo tipo de atividade. Já para a Orsa, este fator também é relevante, embora em menor grau. 
Tabela 24 - Relação entre as empresas analisadas e os impactos decorrentes das ações de responsabilidade social (Ativistas)

\begin{tabular}{c|c}
\hline STAKEHOLDER: & $\begin{array}{c}\text { MINIMIZAÇĀO DE } \\
\text { RISCOS } \\
\text { ATIVISTAS }\end{array}$ \\
\hline SADIA & $\mathrm{XX}$ \\
\hline PERDIGĀO & $\mathrm{XX}$ \\
\hline NESTLÉ & $\mathrm{XXX}$ \\
\hline JARI & $\mathrm{XXX}$ \\
\hline ORSA & $\mathrm{XX}$ \\
\hline
\end{tabular}

Fonte: $\mathrm{O}$ autor.

\section{Comentários:}

A minimização dos riscos de boicotes e campanhas negativas por parte de ativistas é particularmente relevante para a Nestlé, por se tratar de uma grande corporação multinacional e para a Jari, pela exploração de uma atividade industrial em região sensível (Amazônia). Para a Sadia, a Orsa e a Perdigão, este fator também é relevante, embora em menor grau. 
Tabela 25 - Relação entre as empresas analisadas e os impactos decorrentes das ações de responsabilidade social (Investidores)

\begin{tabular}{|c|c|c|}
\hline $\begin{array}{l}\text { STAKEHOLDER: } \\
\text { INVESTIDORES }\end{array}$ & $\begin{array}{l}\text { OPORTUNIDADES } \\
\text { Geraçāo de Valor }\end{array}$ & $\begin{array}{l}\text { MINIMIZAÇAO DE } \\
\text { RISCOS } \\
\text { Minimizar riscos de fuga de } \\
\text { investidores }\end{array}$ \\
\hline SADIA & $x x x$ & $x x x$ \\
\hline PERDIGĀO & $x x x$ & $x x x$ \\
\hline NESTLÉ & $x x$ & $x$ \\
\hline JARI & $x x$ & $x$ \\
\hline ORSA & $x x$ & $x$ \\
\hline
\end{tabular}

Fonte: $\mathrm{O}$ autor.

\section{Comentários:}

Para a Sadia e Perdigão este fator é altamente relevante para a geração de valor aos investidores e minimzação dos riscos de fuga, em função de suas atividades, e pelas estratégias agressivas de crescimento destas empresas via captação de recursos no mercado de capitais nacional e internacional. Para a Nestlé, Orsa e Jari, tal fátor tem menor relevância quanto à fuga de investidores, por serem empresas de capital fechado, embora seja relevante a estratégia para a geração de valor aos potenciais novos investidores. 
Tabela 26 - Relação entre as empresas analisadas e os impactos decorrentes das ações de responsabilidade social (Funcionários)

\begin{tabular}{|c|c|c|}
\hline $\begin{array}{l}\text { STAKEHOLDER: } \\
\text { FUNCIONÁRIOS }\end{array}$ & $\begin{array}{l}\text { OPORTUNIDADES } \\
\text { Aumento de } \\
\text { comprometimento }\end{array}$ & $\begin{array}{l}\text { MINIMIZAÇAO DE } \\
\text { RISCOS } \\
\text { Minimizar riscos de } \\
\text { comportamento }\end{array}$ \\
\hline SADIA & $x x$ & $x$ \\
\hline PERDIGĀO & $x x$ & $x$ \\
\hline NESTLÉ & $x X X$ & $x$ \\
\hline JARI & $x x$ & $x$ \\
\hline ORSA & $x x$ & $x$ \\
\hline
\end{tabular}

Fonte: $\mathrm{O}$ autor.

\section{Comentários:}

A Neslé desenvolve com destaque a área de voluntariado corporativo, agregando funcionários e gerando maior comprometimento e reputação interna, decorrente das práticas de responsabilidade social. Para as demais empresas, as ações de responsabilidade social também são fator de aumento de comprometimento, embora em menor grau. O fator de riscos de comportamento não pareceu relevante em nenhuma das empresas. 
Tabela 27 - Relação entre as empresas analisadas e os impactos decorrentes das ações de responsabilidade social (Consumidores)

\begin{tabular}{|c|c|c|}
\hline $\begin{array}{l}\text { STAKEHOLDER: } \\
\text { CONSUMIDORES }\end{array}$ & $\begin{array}{l}\text { OPORTUNIDADES } \\
\text { Fidelizaçāo }\end{array}$ & $\begin{array}{l}\text { MINIMIZAÇAO DE } \\
\text { RIScOS } \\
\text { Minimizar riscos de má } \\
\text { aceitação/boicote }\end{array}$ \\
\hline SADIA & $x$ & $x X x$ \\
\hline PERDIGĀO & $x$ & $x x x$ \\
\hline NESTLÉ & $x$ & $x x x$ \\
\hline JARI & $x$ & $x x$ \\
\hline ORSA & $x$ & $x$ \\
\hline
\end{tabular}

Fonte: $\mathrm{O}$ autor.

\section{Comentários:}

Para nenhuma das empresas citadas o aspecto da fidelização dos consumidores pareceu relevante. Entretanto, as ações de responsabilidade social agem no sentido de minimizar os riscos de boicote e má aceitação dos produtos, especialmente para as empresas com produtos finais do setor de alimentos. No caso da Jari, tal fator também se destaca, embora em menor grau, em função das crescentes exigências dos compradores internacionais de celulose. Para a Orsa, a relevância deste fator é menor. 
Tabela 28 - Relação entre as empresas analisadas e os impactos decorrentes das açōes de responsabilidade social (Agentes reguladores)

\begin{tabular}{|c|c|c|}
\hline $\begin{array}{l}\text { STAKEHOLDER: } \\
\text { AGENTES } \\
\text { REGULADORES }\end{array}$ & $\begin{array}{l}\text { OPORTUNIDADES } \\
\text { Ação legal favorável }\end{array}$ & $\begin{array}{c}\text { MINIMIZAÇAO DE } \\
\text { RISCOS } \\
\text { Minimizar riscos de ação } \\
\text { legal }\end{array}$ \\
\hline SADIA & $x$ & $x x x$ \\
\hline PERDIGÃO & $x$ & $x x x$ \\
\hline NESTLÉ & $x$ & $x x$ \\
\hline JARI & $x$ & $x x x$ \\
\hline ORSA & $x$ & $x x$ \\
\hline
\end{tabular}

Fonte: $\mathrm{O}$ autor.

\section{Comentários:}

Para todas as empresas, as açōes de responsabilidade social servem mais para minimizar riscos de ações legais, especialmente em relação aos aspectos ambientais, do que para a criação de açōes legais favoráveis. As empresas Perdigão e Sadia, pelo tipo de atividade, são mais suscepitveis a aspectos legais, em função dos riscos inerentes à atividades, tanto na fase de produção rural de seus produtores integrados quanto na fase industrial. A Jari, também pelos potenciais riscos ambientais. Para a Nestlé e Orsa, embora relevante, o risco é menor em relação às demais. 
Tabela 29 - Relação entre as empresas analisadas e os impactos decorrentes das ações de responsabilidade social (Parceiros comerciais)

\begin{tabular}{|c|c|c|}
\hline $\begin{array}{c}\text { STAKEHOLDER: } \\
\text { PARCEIROS COMERCIAIS }\end{array}$ & $\begin{array}{l}\text { OPORTUNIDADES } \\
\text { Colaboração }\end{array}$ & $\begin{array}{c}\text { MINIMIZAÇĀO DE } \\
\text { RISCOS } \\
\text { Minimizar riscos de defecçāo }\end{array}$ \\
\hline SADIA & $x x x$ & $x x x$ \\
\hline PERDIGĀO & $x x x$ & $x x x$ \\
\hline NESTLÉ & $x x$ & $x x$ \\
\hline JARI & $x$ & $x$ \\
\hline ORSA & $x$ & $x$ \\
\hline
\end{tabular}

Fonte: $\mathrm{O}$ autor.

\section{Comentários:}

Para a Sadia e Perdigão, as ações de responsabilidade ligadas aos parceiros comerciais são extremamente relevantes, pelas fortes relações contratuais com produtores integrados de aves e suínos. Para a Nestlé, embora em menor grau, tal fator também é importante, especialmente em relação aos produtores de leite, que se constitui na principal matéria-prima de grande parte de sua linha de produtos. Para Orsa e Jari este fator é menos relevante. 


\subsection{2 - O Modelo de Quazi e O'Brien (2000)}

O modelo de Quazi e O'Brien será utilizado para mapear as visões que levaram à motivação para ações de responsabilidade social por parte das empresas analisadas.

A Figura 10 apresenta a classificação feita com base nas evidências levantadas nos estudos de caso.

Figura 10 - O Modelo de Quazi e O'Brien e a classificação das empresas analisadas

BENEFICIOS DE AÇÕES DE RSC

\section{Visão Moderna}

Visão Filantrópica

PERDIGÃO

SADIA

NESTLE

tesponsabilidade Ampla

JARI

COSTOS DE AÇOES DE RSC

Fonte: Adaptado de Quazi \& O'Brien (2000).

Todas as empresas consideraram que as ações de reponsabilidade social geram mais benefícios do que custos, e portanto classificam-se nos quadrantes superiores.

\section{Visão Clássica}

Responsabilidade Estreita

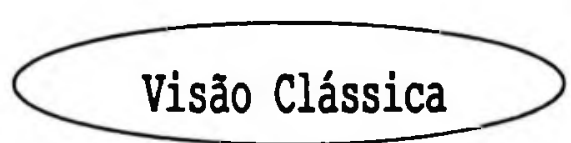


Com relação à percepção das responsabilidades das empresas, a classificação foi feita com base nos tipos de ações desenvolvidos pelas empresas. Pode-se afirmar que as empresas Perdigão, Sadia e Nestlé têm uma abordagem mais pragmática com relação às ações de responsabilidade social, destacando-se que todas as açōes desenvolvidas estão intrínsecamente relacionadas com as atividades de negócios desenvolvidas pelas empresas. Desta forma, as empresas enquadram-se no quadrante de responsabilidade estreita, com a percepção de benefícios das ações de responsabilidade social (Visão Socioeconômica, na tipologia de Quazi e O'Brien).

No caso das empresas Orsa e Jari, as ações de responsabilidade social são desenvolvidas pela Fundação Orsa, com maior independência em relação às estratégias empresariais. $O$ foco das ações de responsabilidade social desenvolvidas tem pouco sinergia com as atividades de negócios desenvolvidas pelas empresas. Neste sentido, Orsa e Jari são classificadas no quadrante da responsabilidade ampliada, com percepção de beneficios das ações de responsabilidade social (Visão Moderna, na tipologia de Quazi e O'Brien).

No modelo de Quazi e O'Brien, os estudos de caso levaram à convergência em favor da responsabilidade social, entre as visões moderna e socioeconômica. De acordo com estas duas visões, as ações de responsabilidade social estariam gerando valor para as empresas.

\subsection{3 - O Modelo proposto no presente trabalho}

As empresas analisadas se enquadraram nas opçōes A (Sadia, Perdigão e Nestlé) e B (Orsa e Jari) do modelo proposto. Nenhuma empresa se enquadrou na Opção $C$, em que as ações sociais são feitas por outros agentes, independentes da empresa e sem vínculação de controle. A figura 11 ilustra as opções do modelo proposto. 
Figura 11 - Classificação das empresas com base na forma de implementação das ações sociais

Opção $A-\underline{A}$ empresa internaliza as atividades, operacionalizando diretamente os projetos sociais

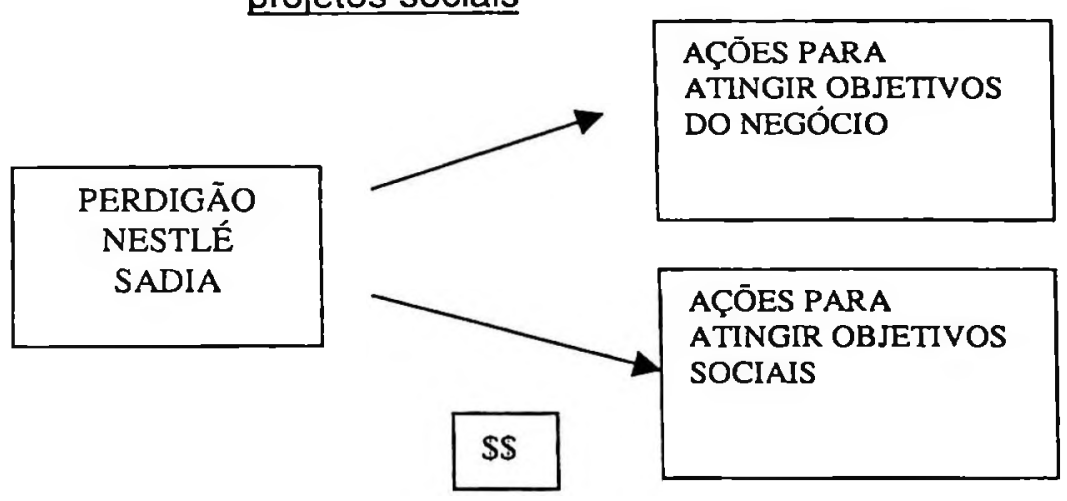

Opção B - A empresa desenvolve ações sociais por meio de outra organização sob seu controle

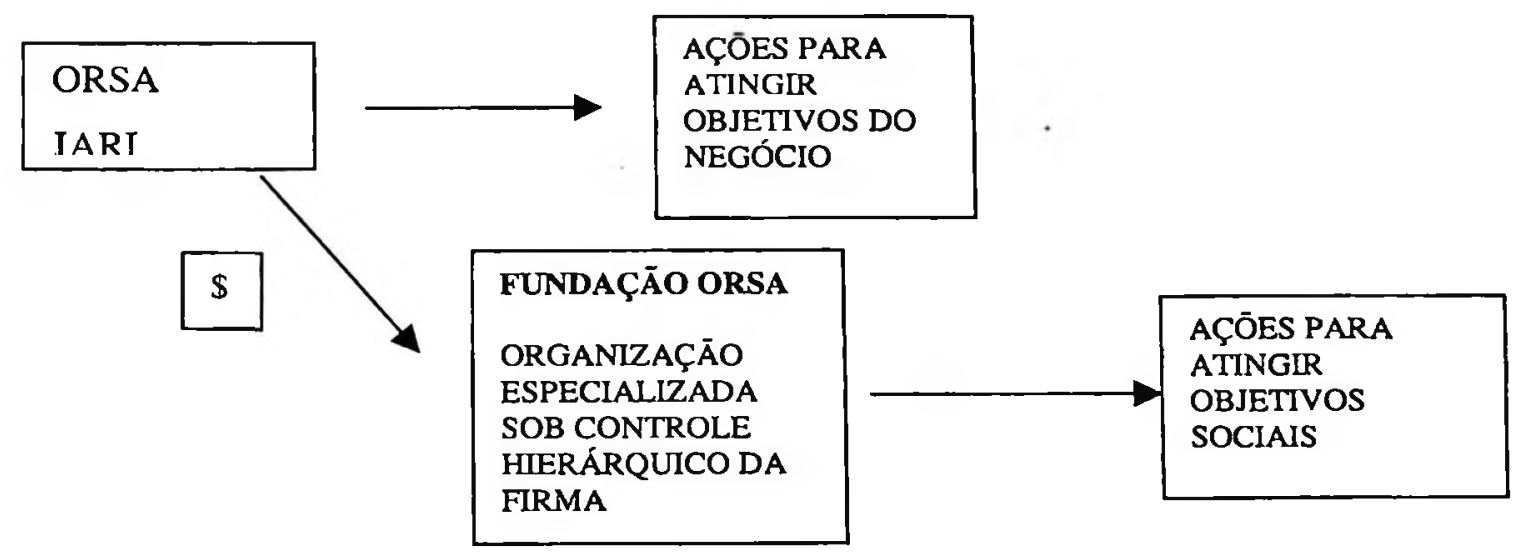

Em função da elevada especificidade das atividades de responsabilidade social em relação às atividades de negócios das empresas, Perdigão, Nestlé e Sadia operacionalizam diretamente seus projetos sociais. Entretanto, especialmente no caso da Sadia e Perdigão, cogita-se a atuação por meio de uma estrutura "fora da firma", mas sob controle da empresa (Opção B), dada a 
elevada escala de atividades sociais desempenhadas pelas empresas e os potenciais problemas de agência.

As empresas Orsa e Jari mantém uma estrutura "fora da firma", sob seu controle hierárquico (Opção B - Fundação Orsa), para o desenvolvimento das ações sociais. Existe menores especificidades entre as atividades sociais desenvolvidas pela Fundação e as atividades de negócios de suas mantenedoras.

Comentários finais - Neste capítulo foi feita a descrição dos estudos de caso do Grupo Orsa (Orsa e Jari), Nestlé, Sadia e Perdigão. Em seguida, procurou-se relacionar as evidências dos casos ao referencial teórico apresentado e às hipóteses de pesquisa. Finalmente, procurou-se sistematizar as principais evidências levantadas para o enquadramento das empresas nos três modelos apresentados.

O capítulo a seguir apresentará a síntese do trabalho, as principais limitações e os direcionamentos propostos para futuros estudos. 
CAPÍTULO 5 - CONCLUSÕES 


\section{1 - SÍNTESE}

Os estudos de caso analisados contribuiram para elucidar uma série de questões e evidenciar as hipóteses sugeridas neste trabalho, ao mesmo tempo em que suscitaram novas questōes e evidenciaram a necessidade de aprofundamento conceitual e empírico.

O presente trabalho resgata a afirmativa de North (1990) de que as "instituições importam" e são passíveis de análise e aperfeiçoamento para a sentido de melhoria da performance econômica e social dos agentes. Neste sentido, as mudanças institucionais, decorrentes da evolução tecnológica, que estão levando à intensificação do fluxo informacional e à internacionalização dos mercados, bem como novos marcos regulatórios especialmente em questões ambientais e sociais, têm induzido as empresas a desenvolverem ações visando a manter ou ganhar reputação. $E$ nesse processo de busca da reputação, cresce a preocupação com o comportamento ético e socialmente responsável.

A outra vertente do trabalho se refere à forma como as empresas se estruturam para desenvolver atividades de responsabilidade social. Foram sintetizadas três formas básicas de atuação social das empresas (direta, via organização especializada sob controle hierárquico, ou via ações spot, como doações ou parcerias, sem a operacionalização). Procurou-se embasar a definição da forma mais eficiente na Economia dos Custos de Transação (ECT) e na teoria de Agência. Os estudos de caso analisados evidenciaram alguns dos condicionantes propostos, quais sejam: a especificidade das ações sociais (ECT) e o alinhamento de interesses entre os gestores das ações sociais (agentes) e os instituidores (principal).

As evidências obtidas dos estudos de caso mostraram que a razão para as empresas internalizarem as suas ações sociais na própria estrutura organizacional são as relações intrínsecas entre a atividade de negócios e o escopo das ações 
de responsabilidade social implementadas (elevada especificidade). Por outro lado, com o aumento na complexidade e na escala das ações sociais, a estruturação de uma organização especializada sob controle hierárquico da empresa parece mostrar evidências de maior eficiência, evitando potenciais problemas de agência.

O debate central que permeou o presente trabalho (visão dos stakeholders versus visão dos stockholders) é pertinente, e na sua essência apresenta visões ideológicas distintas sobre o papel das empresas na sociedade, embora ambas as visões se preocupem com o resultado final, no que se refere ao bem estar social (welfare state). Embora divergentes em seus pressupostos, estas visōes podem convergir na prática. Na percepção do autor, o trabalho de Jensen (2000) captou com clareza a convergência destas visões, ao propor um enfoque que ele denomina enlightened stakeholder theory: as empresas devem ter objetivos claros de criação de valor (value creation), sendo este o parâmetro básico que deve guiar as ações dos gestores. Neste sentido, a função-objetivo clássica da empresa continua vigente. Entretanto, para atingir os objetivos clássicos da empresa, importa cada vez mais a preocupação com o conjunto dos seus stakeholders dai a contribuição desta teoria para a formulação das estratégias das organizações.

Finalmente, o trabalho procurou abordar aspectos mais gerais do problema em estudo (as motivações das empresas para o envolvimento em atividades sociais), sem a pretensão de determinar a generalização da incidência deste fenômeno no universo das atividades de negócios.

\section{2 - LIMITAÇÕES DO TRABALHO - FUTURAS PESQUISAS}

A principal limitação do método de pesquisa de estudos de caso está relacionada com a validação externa dos resultados, ou seja, com o nível de generalização dos resultados obtidos com o estudo. A generalização requer 
processos de amostragem rigorosos e testes estatísticos não possiveis numa pesquisa baseada em estudos de caso.

Outra limitação do método está relacionada à confiabilidade, que indica se as operações envolvidas no estudo de caso (coleta e análise de dados) podem ser repetidas com os mesmos resultados.

Conforme destaca Sykes (1990), a confiabilidade poderia ser verificada se o mesmo estudo, conduzido por outros pesquisadores, produzisse os mesmos resultados. Entretanto, o método de casos pode ser útil no auxílio ao aprimoramento de teorias, conforme já mencionado, sendo esta a situação da presente pesquisa.

Uma série de outros estudos de relevância podem ser desenvolvidos, como o aprofundamento do estudo das várias dimensões da responsabilidade social, estabelecendo-se comparaçōes entre os diversos grupos de stakeholders (consumidores, clientes, fornecedores, acionistas, funcionários, comunidade e governo) buscando-se analisar as diferenças entre as percepções destes grupos sobre a temática da responsabilidade social.

No Brasil, em particular, novas pesquisas podem realizar uma avaliação mais ampla do comportamento do consumidor diante das ações de responsabilidade social, assim como das diferenças na conduta de pequenas, médias e grandes empresas, empresas que atuam com produtos finais versus intermediários, mercado interno versus externo, bens de conveniência versus bens especiais, entre outros tópicos de relevância para a definição de estratégias empresariais, tomando as ações de responsabilidade social como um instrumento para diferenciar de produtos ou serviços.

A questão da forma como a empresa se estrutura para lidar com atividades de responsabilidade social é outro campo de vasto potencial para futuras 
pesquisas. O presente trabalho procurou levantar algumas evidências de formas alternativas de estrutura organizacional com base em alguns pressupostos da Economia dos Custos de Transação e da teoria de Agência. $O$ aprofundamento desta discussão é pertinente do ponto de vista da aplicação prática, e visa a oferecer subsídios para os tomadores de decisão nas empresas.

Adicionalmente, futuras pesquisas poderão investigar de forma mais aprofundada a natureza das diferenças entre as percepções em diferentes ambientes institucionais, diferenças que podem seer determinadas seja por ideologias nacionais diversas ou por discrepância nos valores culturais.

A despeito das limitações, espera-se que este estudo tenha propiciado um melhor entendimento das motivações de empresários e executivos para as ações de responsabilidade social. A expectativa é de que o trabalho tenha agregado valor para o campo de estudo da Economia das Organizações, pela contextualização e aprofundamento analítico do problema de pesquisa. 
REFERÊNCIAS BIBLIOGRÁFICAS 
ALSO, Ronald. Reputação das empresas tem vida longa, para o bem ou para o mal. The Wall Street Journal of Americas in O Estado de S. Paulo, B13, 24 set. 1999.

ANDRIOF J. ; MCINTOSH, M. Perspectives on Corporate Citizenship. UK: Warwick Business School, 2001.

AKERLOF, George A .The Market for Lemons: Quality, Uncertainty and the Market Mechanism. Quartely Jornal of Economics, [S.L.]: 488-500, ago, 1970.

ASSOCIAÇÃO BRASILEIRA DOS ANALISTAS DE MERCADO DE CAPITAIS (ABAMEC). Disponivel em: < http://www.abamec.com.br > . Acesso em: 10 dez.2001.

AOKI, M. The Co-operative Game Theory of the Firm. New York: Oxford University Press, 1984.

ARRUDA, M. C. Coutinho de. Código de Ética. S. Paulo: Negócio Editora, 2002.

ASHLEY, Patrícia (Coord.) Ética e Responsabilidade Social nos Negócios". São Paulo: Saraiva, 2002.

BANCO NACIONAL DO DESENVOLVIMENTO ECONÔMICO E SOCIAL. Empresas, Responsabilidade Corporativa e Investimento Social - Uma abordagem Introdutória. Relatório Setorial 1. Rio de Janeiro: AS/GESET mar., 2000. Balanço Social e Outros Aspectos da Responsabilidade Corporativa" - Relatório Setorial 2. Rio de Janeiro: AS/GESET mar., 2000. 
BEEKUN, Rafik; STEDHAM Yvone; YAMAMURA, Jeanne H. Business Ethics in Brazil and the U.S. : Egoism and Utilitarianism, Social Science Research Network Eletronic Library. [S.L.]: Working paper series.

Disponivel: < http://papersssrn.com/paper.taf?abstract id 272036> . Acesso em: 18 jun. 2001.

BESANKO, David et.al. Economics of Strategy, N.Y.: John Wiley \& Sons, 2000.

BRICKLEY, James; SMITH JR, Clifford; ZIMMERMAN, Jerold L. Business Ethics and Organizational Architecture. Social Science Research Network Eletronic paper Collection. [S.L.]:nov.,2000 .

Disponivel: http://papers.ssrn.com/paper.taf?abstract id250947. Acesso em: 16 dez., 2000.

BONOMA, T.V. Case Research in Marketing: opportunities, problems and a process. Journal of Marketing Research, v.22, mai., 1985.

BORGER, Fernanda G. Responsabilidade Social: Efeitos da Atuação Social na Dinâmica Empresarial. Tese de Doutorado. São Paulo: FEA/USP, 2001.

BUSINESS SOCIAL RESPONSIBILITY (BSR). Social Responsibility. [S.L.]: Disponível: < http// www.bsr.org> . Acesso em: 14, março, 2001.

CARDOSO, Ruth. Cidadania Empresarial: O Desafio da Responsabilidade. Update Br/Eua, Amcham, n. 363, p. 115-120, ago., 2000.

CARROLL, Archie. Corporate Social Responsibility. Business and Society, vol 28 , set. 1999 .

A Three-Dimensional Conceptual Model of Corporate Performance . Academy of Management Review . [S.L.]: n.4, p. 497-505, 1979. 
CASTRO, C.C. A Prática da Pesquisa. São Paulo: Mc Graw Hill, 1978.

CENTRO DE ESTUDOS EM ADMINISTRAÇÃO DO TERCEIRO SETOR (CEATS). Relatório preliminar de pesquisa intitulado Alianças Estratégicas Intersetoriais para Atuação Social'. Apresentado à Faculdade de Economia, Administração e Contabilidade da USP. São Paulo, 13, dez. 2001.

CERTO, Samuel ; PETER, J. Paul. Administração Estratégica, Makron Books, 1993.

CHAUVIN, Keith W. ; JAMES, Guthrie. Labor Market Reputation and the Value of the Firm. Managerial and Decision Economics. v. 15, p.543-552, 1994.

CHAUVIN, Keith; HIRSCHEY, Mark. Godwill, Profitability and Market Value of the firm. Journal of Accounting and Public Policy. [S.L.]: v.13, p. 159-180, 1994.

CORNING, Beth. Great Reputations. Accountancy. [S.L.]: v. 123, p. 38-39, mar., 1999.

DE LUCA, Márcia. Demonstração do Valor Adicionado: Do Cálculo da Riqueza criada pela Empresa ao Valor do PIB. São Paulo: Ed. Atlas, 1998.

DIENHART, John W. Business, Institutions and Ethics. New York: Oxford University Press, 2000.

ECO, Umberto. Como se faz uma Tese. São Paulo: ed. Perspectiva, 2001.

ETHICAL PERFORMANCE. Unibanco Leads the way in Brazil with Ethical Research Service. Newsletter, v. 2 n.9. [S.L]: Disponível em: <http:// www.ethicalperformance.com> Acesso em: 01 mar. 2001. 
FISCHER, Rosa ; FALCONER, Andres. Estratégias de empresas no Brasil: atuação social e voluntariado. Relatório de Estudo do Centro de Estudos em Administração do Terceiro Setor da USP (CEATS), 1999.

FOMBRUN, Charles - Reputation: Realizing Value from the Corporate Image. Boston: HBS Press, 1996.

FOMBRUN, Charles et.al. Opportunity Platforms and Safety Nets: Corporate Citizenship and Reputational Risk. Business and Society Review, Malden, MA: Blackwell Publishers, 105: 1 p. 85-106, 2000.

FORTUNE. World's Most Admired Companies. Switzerland: vol 145 n.5 Europe edition, 11 mar., 2002.

FRANCESCO, A. M. ; GOLD, B. A . International Organizational Behaviour. New Jersey: Prentice Hall, 1998.

FREEMAN, E. A Stakeholder Theory of the Modern Corporation. In: DIENHART, John W. Business, Institutions and Ethics. New York: Oxford University Press, 2000.

FRIEDMAN, Milton. The Social Responsibility of Business is Increase Its Profits. N.Y.: New York Times Magazine, 13 set., 1970. Capitalism and Freedom. Chicago: University of Chicago Press, 1962.

FUNDAÇÃO ORSA (Brasil). Relatório: Era uma vez um sonho. São Paulo, 2001. 
GARBETT, T. How to Build a Corporation's Identity and project its Image. [S.L.]: Lexington Books, 1988.

GIBSON, Kevin. The Moral Basis of Stakeholder Theory. Journal of Business Ethics. Netherlands: Kluwer Academic Publishers. n.26, p. 245-257, 2000.

GIANETTI DA FONSECA, E. Vícios Públicos, Benefícios Privados. São Paulo: Companhia das Letras, 1994.

GRAY, Edmund R. ; BALMER, John M. T. Managing Corporate Image and Corporate Reputation. Long Range Planning. [S.L.]: P. 695-702, out., 1998.

GRUPO ORSA (Brasil). Relatório Anual. São Paulo, 2000/2001.

GOODPASTER, K. E. Business Ethics and Stakeholder Analysis. Business Ethics Quarterly, n.1, p. 53-73, 1991.

HANKA, Gordon. Does Wall Street Want Firms to Harm Their Neighbors and Employees?.In: JONES, Kari ; RUBIN, Paul H. Effects of Harmful Environmental Events on Reputation Firms. working paper, Social Science Research Network Eletronic Library, abr., 1999. Disponível em: < http://papers.ssrn.com.taf?abstract id158849>. Acesso em: 03 set.1999.

HARTMANN, L. Technology and Ethics: Privacy in the Workplace. Bentley College: Center for Business Ethics, 2000.

HOFSTEDE, Geert. Culture's Consequences: International Differences in Work-Related Values.In: BEEKUN, Rafik; STEDHAM Yvone; YAMAMURA, Jeanne H. Business Ethics in Brazil and the U.S. : Egoism and Utilitarianism, 
Social Science Research Network Eletronic Library. [S.L.]: Working paper series, id 272036, junho, 2001.

Disponivel: < http://papersssrn.com/paper.taf?abstract id 272036>. Acesso em 18 jun. 2001.

INSTITUTO BRASILEIRO DE GOVERNANÇA CORPORATIVA (IBGC). Disponivel em: < http:// www.ibgc.org.br>. Acesso em: 10 nov 2001.

INTERNATIONAL FOOD AND AGRIBUSINESS MANAGEMENT ASSOCIATION (IAMA). Disponivel em: < http:// www.ifama.org>. Acesso em: 18 nov. 2001

INSTITUTO ETHOS. Relatório de Pesquisa Ethos/Valor. Elaborado pela Indicator Opinião Pública. Disponível em: <http// www.ethos.org.br.> Acesso em: 13 mar. 2001. _ Guia de Elaboração de Relatório e Balanço Anual de Responsabilidade Social Empresarial. São Paulo: Instituto Ethos, versão 2001.

JARI (Brasil). Relatório Anual. Rio de Janeiro, 2000.

JENSEN, Michael. Value Maximization, Stakeholder Theory and the Corporate Objective Function. Boston: Harvard Business School. Working Paper 00-058, abr., 2000.

JONES, Kari ; RUBIN, Paul H. Effects of Harmful Environmental Events on Reputation Firms. working paper, Social Science Research Network Eletronic Library, abr., 1999. Disponível em: < http://papers.ssm.com.taf?abstract id158849». Acesso em: 03 set. 1999.

JONES, Marc T. The Institutional Determinants of Social Responsibility. Journal of Business Ethics. Netherlands: Kluwer Academic Publishers. v. 20, p. 163-179, 1999. 
JONES, M. Instrumental Stakeholder Theory: A Synthesis of Ethics and Economics. Academy of Management Review. [S.L.]: v.20, p.404-437, 1995.

JONES, Ray; MURRELL, Audrey. Signaling Positive Corporate Social Performance. Business \& Society, [S.L.]: Sage Publications, v. 40, n.1, p. 59-78, mar., 2001.

LEO, Sérgio. BNDES realiza seminário sobre responsabilidade social Corporativa. Jornal Valor Econômico. São Paulo: cad. B, p.2, 18 out., 2001.

KOEHN, Daryl. Ethical Challenges Confronting Business Today. In: International Symposium on Ethics, Business and Society, 11. Anais... Barcelona: IESE, 2001.

LAZZARINI, S.G. Estudos de Caso para Fins de Pesquisa: Aplicabilidade e Limitações do Método. In: FARINA et. al. (Coord). Estudos de Caso em Agribusiness. São Paulo: ed. Pioneira, p. 9-23, 1997.

LINS, Cristóvão. A Jari e a Amazônia. Almeirim/PA: Dataforma, 1997.

MCWILLIAMS, Abagail; SIEGEL, Donald. Corporate Social Responsibility: A Theory of Firm Perspective. Academy of Management Review. [S.L.]: v.26, n.1, p. 117-127, 2001.

MAIGNAN, Isabelle. Consumer's Perceptions of Corporate. Social Responsibilities: A cross-cultural Comparison. Journal of Business Ethics. Netherlands: Kluwer Academic Publishers. v.30,: p. 57-72, 2001.

MARENS, Richard; WICKS, Andrew. Getting real: Stakeholder Theory, managerial Practice, and the General Irrelevance of Fiduciary Duties Owed to 
Shareholders. In: DIENHART, John W. Business, Institutions and Ethics. New York: Oxford University Press, 2000.

MEIO CIRCULANTE. Banco Real/Abn Amro lança o primeiro fundo Ético no Brasil. São Paulo: Boletim do Projeto Eco-finanças de Amigos da Terra, p.2, ano 2, n. 5, dez. $2001 /$ jan.2002.

Corporate Governance: Por que se fala tanto no assunto?. São Paulo: Boletim do Projeto Eco-finanças de Amigos da Terra, p.4, ano 2, n. 5, dez. $2001 /$ jan.2002.

MILES, Morgan ; COVIN, Jeffrey. Environmental Marketing: A Source of Reputational, Competitive and Financial Advantage. Netherlands: Kluwer Academic Publishers. Journal of Business Ethics, ed.23, p. 299-311, 2000.

MILGROM, Paul ; ROBERTS, John. Economics, Organization and Management. New Jersey: Prentice Hall, 1992.

NESTLÉ (Brasil). Relatório: Princípios Nestlé de Gestão Empresarial. São Paulo, [2000?].

NESTLÉ (Brasil). Relatório: Conhecendo os Alimentos. Roteiro Pedagógico do Programa Nutrir. São Paulo, [2001?].

NORTH, DOUglass C. Institutions, Institutional Change and Economic Performance. Cambridge: Cambridge University Press, 1990.

Custos de Transação, Instituições e Desempenho Econômico. São Paulo: Instituto Liberal, 38 p., 1994.

Q OLIVEIRA Neto, W. Responsabilidade Social no Brasil e no Mundo. Revista Mercado Global. São Paulo: ed. Globo. n.107, p. 51-54, 1999. 
OSTAS, Daniel. Deconstructing Corporate Social Responsibility: Insights from Legal and Economic Theory. American Business Law Journal. [S.L.]: v.38, P. 261-299, 2001.

PAINE, Lynn Sharp. Managing for Organizational Integrity. In: DIENHART, John W. Business, Institutions and Ethics. New York: Oxford University Press, 2000.

PETTIGREW, A . M. Contextualist research: a natural way to link theory and practice. In: LAZZARINI, S.G. Estudos de Caso para Fins de Pesquisa: Aplicabilidade e Limitações do Método. In: FARINA et. al. (Coord). Estudos de Caso em Agribusiness. São Paulo: ed. Pioneira, p. 9-23, 1997.

PERDIGÃO (Brasil). Relatório: Investindo no ser Humano. São Paulo, 2000/2001

PERDIGÃo (Brasil). Relatório: Perdigão Hoje, n. 24. São Paulo, dez. 2000/jan. 2001.

PERDIGÃO (Brasil). Relatório Anual. São Paulo, 2001.

PETRICK, Joseph et.al. Global Leadership Skills and Reputational Capital: Intangible Resources for Sustainable Competitive Advantage. Academy of Management Executive. [S.L.]: v.13, n.1 p. 58-69, 1999.

PINDYCK, R.S. ; RUBINFELD, D.L. Microeconomia. Makron Books do Brasil, 1994.

PINHEIRO MACHADO, Cláudio. A . ; ZYLBERSZTAJN, Decio. A Fundação de uma Empresa Social. Revista Case Studies, n.15, mai/jun., 1999. 
QUAZI, Ali \& O'BRIEN, Dennis. An Empirical Test of a Cross-National Model of Corporate Social Responsibility. Journal of Business Ethics. Netherlands: Kluwer Academic Publishers. V.25, p. 33-51, 2000.

QUAZI, Ali. Corporate Social Responsibility in Diverse Environments: A Comparative Study of Managerial Attitudes in Australia and Bangladesh. Business \& Professional Ethics Journal, p.67-84, 1997.

Revista EXAME. Maiores e Melhores. São Paulo: editora abril, jun. 2001. Guia de Boa Cidadania Corporativa. São Paulo: Editora Abril, ed. 754, 2001.

Abril, ed. 728, 2000. Guia de Boa Cidadania Corporativa. São Paulo: Editora 100 Melhores Empresas para Você Trabalhar. São paulo: Editora Abril, ed. 749, 2001.

Revista VOCÉ S. A . Dinheiro Socialmente Responsável. São Paulo: Editora Abril. ed. 44, p. 75, fev. 2002.

RIBEIRO, Renato J. Prometeu versus Narciso: a Ética e a Clonagem. Pesquisa FAPESP. São Paulo: n.73, mar., 2002. Suplemento especial.

SADIA (Brasil). Relatório Anual. São Paulo, 2000/2001.

SADIA (Brasil). Relatório Social. São Paulo, 2000/2001.

SAFATLE, Amália. As Boas Açoes - Indice formado por papéis de empresas socialmente responsáveis traz ganho maior que o Dow Jones. In: Carta Capital. São Paulo, p.70, 08 nov. 2000. 
SCHWARTZ, R. A . Corporate Philanthropic Contributions. The Journal of Finance, v.23, p. 479-497, 1968.

SEN, Amartya. Sobre Ética e Economia. São Paulo: Cia das Letras, 1999.

SHAW, William H. Business Ethics. Belmont, CA: Wadsworth, 1999.

SHENKAR, Oded \& YAAR, Epchraim. Reputation, Image, Prestige and Goodwill: An Interdisciplinary Approach to Organizational Standing. Human Relations. [S.L.]: v. 50, n.11, 1997.

SMITH N. Craig. Corporate Citizenship and Their Critics. In: MAIGNAN, Isabelle. Consumer's Perceptions of Corporate Social Responsibilities: A crosscultural Comparison. Journal of Business Ethics. Netherlands: Kluwer Academic Publishers. v.30,: p. 57-72, 2001.

STERNBERG, Elaine. The Stakeholder Concept: A Mistaken Doctrine. Leeds: Foundation for Business Responsibilities, Issue paper n.4. nov. 1999.

SYKES, W. Validity and Reliability in Qualitative Market Research: a review of Literature. Journal of the Marketing Research Society, v.32, n.3, 1990.

TADELIS, Steven. What's in a Name? Reputation as a Tradeable Asset. The American Economic Review, [S.L.]: p. 548-563, jun. 1999.

TEECE, David J. Capturing Value from Knowledge Assets: The New Economy, Markets for Know-How and Intangible Assets. [S.L.]: Califormian Management Review, v. 40, n. 3, Spring 1998.

UNIBANCO (Brasil) Relatório: Perdigão: Socially Responsible Investing Company Profile. Jan.,2001. 
VASSALO, Cláudia. Um Novo Modelo de Negócios. Revista Exame. São Paulo, Editora Abril, ed. 728, p. 8-11, 2000.

YIN, R.K. Case Study Research: Design and Methods. Newbury Park: SAGE Publications, 1989. Edição cultural.

WILLIAMSON, Oliver E. The Economic Institutions of Capitalism. New York: Free Press, 1985.

The Mechanisms of Governance. New York: Oxford University Press, 1996.

Transaction Cost Economics and Organizational Theory. Journal of Industrial and Corporate Change. v. 2, p.107-156, 1993.

WILLIAMS, Robert J. ; BARRET, Douglas. Corporate Philanthropy, Criminal Activity and Firm Reputational: Is There a Link? Journal of Business Ethics. Netherlands: Kluwer Academic Publishers, v. 26, p. 341-350, 2000.

WINKLEMAN, Michael. The Right Stuff. Chief Executive. [S.L.]: p.80-81, abr. 1999.

WRIGHT, Peter ; KROLL, M. ; PARNELL, J. Administração Estratégica. São Paulo: Ed. Atlas, 2000.

ZYLBERSZTAJN, Decio. A Organização Ética: um ensaio sobre as relaçōes entre ambiente econômico e o comportamento das organizaçōes. Working Paper. texto base de aula de erudição para obtenção do título de professor titular. São Paulo, . São Paulo, Faculdade de Economia, Administração e Contabilidade/USP, 2000.

Atitude Ética para Melhorar Imagem e Lucrar. Gazeta Mercantil, São Paulo, p. A 3, 30 mar. 2000. 
Estruturas de Governança e Coordenação do Agribusiness : Uma aplicação da Nova Economia das Instituições". Tese de Livre Docência em Administração. São Paulo, Faculdade de Economia, Administração e Contabilidade/USP, 1995.

ZYLBERSZTAJN, Decio \& NEVES, Marcos. F. (Coord.). Economia \& Gestão dos Negócios Agroalimentares. São Paulo, ed. Pioneira, 2000.

ZYLBERSZTAJN, Decio ; ZUURBIER, Peter. A Non Naive Explanation of Trust: Avoiding Mistaken Decisions for Agribusiness Chain Management. Working Paper. São Paulo, FEA/USP, 1999 


\section{ANEXO 1 - INSTRUMENTO DE PESQUISA QUALITATIVA}

\section{ROTEIRO BÁSICO DE ENTREVISTA}

1. Tipos de ações de responsabilidade social desenvolvidas pela empresa

2. Razões que levaram a empresa a investir em ações de responsabilidade social

3. As ações de responsabilidade social são práticas comuns entre as principais empresas concorrentes?

4. Existem critérios relativos a retorno econômico para seleção das ações de responsabilidade social em que a empresa se engaja?

5. Estimativa de valores (percentuais ou absolutos) de gastos em atividades de responsabilidade social

6. Percepções de benefícios diretos ou indiretos para a empresa:

6.1 - Melhoria da imagem/reputação corporativa?Evidências?

6.2 - Melhoria do relacionamento com órgãos governamentais?Evidências?

$6.3-$ Melhoria do relacionamento com investidores? Evidências?

6.4 - Apoio nas vendas ou diferenciação dos produtos/serviços? Evidências?

6.5 - Melhoria no relacionamento com os funcionários?

6.6 - Melhoria das relações ao longo da cadeia produtiva? Clientes e fornecedores? Evidências?

6.7 - Existe algum critério de mensuração do retorno econômico para a empresa?

7. A Empresa divulga suas ações de responsabilidade social?

8 - Estrutura organizacional para lidar com ações de responsabilidade social: direta /via fundação própria /entidades parceiras. Justificativa para a forma escolhida. 


\section{ANEXO 2 - ENTREVISTAS E DEPOIMENTOS OBTIDOS}

Sérgio Garcia Amoroso - Grupo ORSA

Presidente da Holding Grupo Orsa

José Cláudio Sardinha - Jari Celulose

Presidente

Ana Maria Vianna - Jari Celulose

Diretora Comercial

Cristóvão Lins - Jari Celulose

Relações Públicas

Rubens Tocci - Jari Celulose

Relações Institucionais

Roberto Rivetti - Fundação Orsa

Coordenador da Fundação Orsa

Sandra Campos - Nestlé

Assuntos Corporativos

Ricardo Menezes - Perdigão Agroindustrial

Diretor de Relações Institucionais

José Fernando Monteiro Alves - Sadia

Consultor da Presidência do Conselho

Beatriz Azeredo - BNDES

Diretora da Área Social

Cláudia Soares Costa - BNDES

Gerente da Área Social

Christopher Wells - Unibanco

Social Report Investment (SRI) Analyst 